\title{
Aristóteles e a Lógica da Contingência \\ Uma interpretação tradicional do argumento da batalha naval
}

Luiz Henrique Lopes dos Santos

Since Antiquity, the meaning and purpose of Aristotle's sea-battle argument have been highly controversial. On the so-called traditional interpretation of De Interpretatione 9, the argument is intended to prove that not every statement is always true or false on the assumption deemed evident that facts may occur contingently in our sublunar world. In this paper I argue that this interpretation is for many reasons much more plausible than any of its competitors, so that its correctness is worthy at least of moral certainty. In particular, I contend that it can coexist in perfect logical harmony with a moderately charitable reading of Aristotle's texts that at first glance it seems to confute. As a matter of fact, I contend that it is faithful to Aristotle's view of logical laws as consequent upon the metaphysical structure of reality.

O determinismo, no sentido mais amplo da expressão, é a tese de que tudo o que existe ou acontece esteve, por qualquer razão que seja, desde sempre inflexivelmente determinado a existir ou acontecer, no exato momento em que existe ou acontece. Segundo o conceito mais amplo de necessidade, o mais frequentemente utilizado por Aristóteles, existe ou acontece por necessidade o que, antes de existir ou acontecer, já estava inflexivelmente determinado, por qualquer razão que seja, que viria a existir ou acontecer, no exato momento em que existe ou acontece. À luz desse conceito, o determinismo é a tese de que tudo existe e acontece por necessidade. E chama-se de determinismo lógico a tese de que o determinismo pode ser assentado sobre princípios lógicos.

Até onde nosso conhecimento histórico alcança, o debate filosófico sobre o determinismo lógico foi inaugurado há pouco menos de 2.500 anos, tendo sido então alimentado por dois argumentos: o chamado argumento dominador, atribuído a Deodoro 
Cronos, e o chamado argumento da batalha naval, exposto por Aristóteles no capítulo 9 do tratado De Interpretatione. Curiosamente, esses dois argumentos tiveram um destino histórico comum: é até hoje controverso o que sejam eles.

No caso do argumento dominador, sabe-se com certeza quais são suas premissas: o passado é necessário e do possível não se segue o impossível. E sabe-se com certeza que sua conclusão é o que hoje chamamos de princípio de plenitude: todo possível é ou será. No entanto, nenhuma fonte, direta ou indireta, nos informa cabalmente por meio de quais passos inferenciais a conclusão teria sido extraída das premissas.

Já a situação do argumento da batalha naval é ainda mais grave. Desde a Antiguidade, é controverso quais sejam as próprias premissas e a própria conclusão do argumento. Diferentes comentadores encontram, em De Interpretatione 9, argumentos com conclusões não apenas diferentes, mas incompatíveis, que entendem serem derivadas de premissas não apenas diferentes, mas incompatíveis.

Por um lado, a letra fria do capítulo parece não ser realmente passível de interpretação indisputável, isenta de dificuldades e imune a suspeitas de artimanhas ad hoc. Por outro lado, o grau de plausibilidade de uma das interpretações já propostas para o capítulo parece ser tão maior que o de suas concorrentes no mercado, e os problemas que ela indiscutivelmente enfrenta parecem ser tão mais facilmente superáveis, que sua correção parece merecedora, quando menos, de certeza moral.

Essa interpretação é aquela que se costuma chamar de tradicional, talvez inadequadamente, pois é controverso que tenha sido dominante entre os herdeiros e comentadores antigos e medievais de Aristóteles. Em seu comentário às Categorias, Simplício atribui a um tal Nicostrato (provavelmente um filósofo platônico do século II D.C.) a tese que a interpretação tradicional encontra exposta em De Interpretatione 9 e diz que ela teria sido rejeitada pelos filósofos que chama de peripatéticos. ${ }^{1}$ Como esse testemunho data de mais de 800 anos após a morte de Aristóteles, não se sabe qual a amplitude temporal da referência aos peripatéticos, muito menos se, entre os peripatéticos, Simplício conta o próprio Aristóteles. O testemunho é, no entanto, suficiente para comprovar pelo menos a relutância de seguidores antigos de Aristóteles em avalizar, irrestrita e literalmente, a interpretação dita tradicional do capítulo.

Na verdade, há bons indícios de que essa interpretação tenha sido prazerosamente difundida pelos opositores de Aristóteles (particularmente pelos estoicos, segundo o

\footnotetext{
${ }^{1}$ Cf. Simplício, Comentário às Categorias, 406, 5-16; 406, 34-407, 14.
} 
testemunho de Boécio $^{2}$ ) com o intuito de desacreditá-lo filosoficamente. Isso porque o capítulo conteria, segundo ela, nada mais e nada menos que um argumento em favor da tese de que não tem validade universal o que parece ser um princípio fundamental da lógica, o que hoje chamamos de princípio de bivalência: todo enunciado é verdadeiro ou falso. $^{3}$

Não é de espantar que os peripatéticos se sentissem desconfortáveis com a atribuição desse argumento ao fundador de sua escola. Com efeito, à luz das definições de verdade e falsidade formuladas em muitos textos aristotélicos, o princípio de bivalência parece ser equivalente ao princípio do terceiro excluído, segundo o qual é necessariamente verdadeira a disjunção entre um enunciado qualquer e sua negação. Ora, Metafísica IV 7 inclui o princípio do terceiro excluído, em conjunção com o de não contradição, entre os fundamentos primeiros do ser e do pensamento em geral, em um trecho que sugere ser ele equivalente ao de bivalência.

Por outro lado, tampouco pode haver um intermediário entre os contraditórios, mas é necessário ou afirmar ou negar o que quer que seja a respeito do que quer que seja. Isso fica claro uma vez definidos o verdadeiro e o falso; pois é falso dizer não ser o que é e ser o que não é, é verdadeiro dizer ser o que é e não ser o que não é, de modo que quem diz ser ou não <ser> ou diz o verdadeiro ou diz o falso. (Metafísica IV 7, 1011b23-28)

Além disso, Aristóteles considera ser tão estreito o vínculo entre enunciados e o predicado de ser verdadeiro ou falso que ao menos dois textos seus parecem implicar que esse predicado seria a marca distintiva essencial do discurso enunciativo, a que o distinguiria das outras espécies de símbolos e discursos.

Nenhum desses <termos ditos sem nenhuma combinação> de que falamos é dito, por si mesmo, como uma afirmação, mas é pela combinação de uns com outros que se produz a afirmação. Com efeito, considera-se que toda afirmação é verdadeira ou falsa, mas o que é dito sem nenhuma combinação (como homem, branco, corre, vence) não é nem verdadeiro nem falso. (Categorias $4,2 \mathrm{a} 4-10)$

No entanto, nem todo <discurso> é enunciativo, mas o é aquele em que estão a verdade ou a falsidade, que não estão em todos: uma súplica, por exemplo, é decerto um discurso, mas nem verdadeiro nem falso. (De Interpretatione 4, 17a1-5)

Seja como for, e malgrado o compreensível desconforto dos peripatéticos, creio

\footnotetext{
${ }^{2}$ Boécio, Segundo Comentário ao De Interpretatione, 208, 1-7

${ }^{3}$ A bem dizer, a expressão "interpretação tradicional" deve ser tomada como um termo geral, aplicável a interpretações que, mesmo divergindo quanto ao entendimento de trechos particulares do capítulo, concordam em nele encontrar uma refutação da validade universal do princípio de bivalência. Por isso, este artigo expõe uma interpretação tradicional.
} 
que a interpretação tradicional se impõe por seu poder explicativo em relação à totalidade do capítulo, incomparavelmente maior que o de suas concorrentes. Pode-se mostrar que ela dá conta de por que cada frase do capítulo nele aparece, no lugar em que aparece e, também, de por que o capítulo aparece no tratado, no lugar em que aparece. Além disso, pode-se mostrar que as dificuldades que a desafiam, cuja origem está em um pequeno trecho no final do capítulo, que parece favorecer outras interpretações, na verdade são mais facilmente (ou menos dificilmente) superáveis que as dificuldades que confrontam essas interpretações.

O conjunto do que não se pode sensatamente questionar que um texto filosófico contenha é um dos parâmetros essenciais para a mensuração do poder explicativo de uma interpretação proposta para esse texto. Comecemos, pois, por distinguir o que, em $D e$ Interpretatione 9, é inquestionável e, portanto, deve ser preservado por qualquer interpretação plausível do texto.

Antes de mais nada, é inquestionável que ele pode ser dividido, a grosso modo, em três partes principais. Na parte inicial, bastante breve (18a28 - 18a33), Aristóteles propõe uma tese. É uma tese negativa: algo que vale universalmente para enunciados sobre o presente e o passado não vale universalmente para enunciados sobre singulares que estão por vir a ser. É inquestionável que, qualquer que seja essa tese, ela tem algo a ver com o que foi estabelecido em De Interpretatione 7, cujo assunto é o modo como verdade e falsidade se distribuem no interior de pares de enunciados opostos, isto é, pares constituídos por uma afirmação e uma negação com o mesmo termo sujeito e o mesmo termo predicado.

Na segunda parte (18a34 - 19a22), é inquestionável que Aristóteles expõe um argumento por redução ao absurdo contra a tese da validade universal do princípio de bivalência. Não é, porém, inquestionável qual seja esse argumento, nem que Aristóteles avalize sua correção. É inquestionável que a primeira etapa desse argumento (18a34$18 \mathrm{~b} 25)$ é um subargumento (chamado de argumento determinista) que, da hipótese da validade universal do princípio de bivalência (a hipótese da redução), pretende inferir a tese determinista. É inquestionável que, na segunda etapa do argumento redutivo (18b26 - 19a22), Aristóteles acredita mostrar que a tese determinista tem consequências evidentemente absurdas, de modo que tudo o que a implique deve ser rejeitado.

$\mathrm{Na}$ terceira e última parte $(19 \mathrm{a} 23$ - 19b4), é inquestionável que Aristóteles formula a tese que o capítulo pretende estabelecer (não sendo, contudo, inquestionável qual seja ela), e produz um argumento para fundamentá-la. De todo modo, é 
inquestionável que essa tese consiste na negação de que algo que vale para todos os enunciados sobre o presente e o passado também vale para todos os enunciados sobre o futuro.

Segundo a interpretação tradicional, a tese proposta na primeira parte do capítulo é a negação da validade universal do princípio de bivalência e, consequentemente, de uma outra tese que, à luz dos princípios de não contradição e das definições aristotélicas de verdade e falsidade, parece lhe ser equivalente: dado um par qualquer de enunciados contraditórios, no sentido logicamente estrito, um deles é verdadeiro e o outro é falso. São contraditórios, no sentido logicamente estrito, dois enunciados tais que um afirma ser o caso precisamente o que o outro nega que seja o caso. Para dispor de um rótulo, eu a chamarei de lei de distribuição dos valores de verdade. Prudentemente, em vez da expressão "princípio de bivalência", passarei a usar "lei de bivalência". A tese proposta na primeira parte do capítulo seria: as leis de bivalência e distribuição valem universalmente para enunciados sobre o presente e o passado, mas não para os enunciados sobre o futuro.

$\mathrm{Na}$ terceira parte, segundo essa interpretação, Aristóteles apresenta, como conclusão do capítulo, a negação da validade universal da lei de distribuição dos valores de verdade, que se toma como equivalente à negação da validade universal da lei de bivalência - ou seja, apresenta como conclusão do capítulo precisamente a tese proposta na parte inicial. Extrai essa conclusão porque considera que o argumento determinista exposto na segunda parte é formalmente impecável, de modo que a validade universal da lei de bivalência (a hipótese da redução), que se toma como equivalente à validade universal da lei de distribuição, tem consequências evidentemente inaceitáveis. A conclusão do capítulo seria exatamente a tese proposta inicialmente.

A interpretação tradicional preserva, portanto, tudo o que o texto do capítulo inquestionavelmente contém. Para atender ao mesmo requisito, qualquer interpretação alternativa, se não encontrar nesse texto uma redução ao absurdo impecável da validade universal da lei de bivalência, deve satisfazer ao menos duas condições.

Em primeiro lugar, deve identificar, na parte final do capítulo, a razão pela qual, para Aristóteles, o argumento determinista seria falacioso - por conter, talvez, alguma premissa falsa, explícita ou implícita, ou, quem sabe, algum passo inferencial espúrio. Em segundo lugar, deve encontrar expresso, nas primeiras e nas últimas linhas do capítulo, o que nele Aristóteles alegadamente afirma que vale para todos os enunciados sobre o presente e o passado, mas não para todos os enunciados sobre o futuro. Evidentemente, 
essas condições devem ser satisfeitas sem desrespeito a um dos princípios básicos da análise e explicação de textos filosóficos: o princípio da caridade, segundo o qual apenas in extremis é admissível apresentar o texto analisado como um discurso escandalosamente incoerente.

Levemos, então, a disputa entre as interpretações ao tribunal do próprio texto. Vejamos o que ele tem a nos dizer, à luz da chave interpretativa dita tradicional, e, em seguida, o que resulta de sua leitura à luz de duas chaves alternativas, que creio serem as únicas dotadas do grau mínimo de plausibilidade aparente que justifique serem ao menos consideradas.

\section{A Tese}

[18a28-33] A respeito do que é e do que veio a ser, [1] é necessário a afirmação ou a negação ser verdadeira ou falsa, e [2] a respeito do universal tomado universalmente, sempre ser uma verdadeira e a outra falsa, e [3] também a respeito dos singulares, como já foi dito; [4] mas a respeito do universal dito não universalmente, não é necessário, o que também já foi dito. [5] No entanto, a respeito dos singulares que estão por vir a ser ( $\tau \tilde{\omega} v \kappa \alpha \theta^{\prime}$ '̌́ $\left.\alpha \sigma \tau \alpha \kappa \alpha i ̀ ~ \mu \varepsilon \lambda \lambda o ́ v \tau \omega v\right)$, não é assim (ở ó $\mu o i ́ \omega \varsigma)$.

A compreensão desse trecho requer a resolução de três ambiguidades gramaticais. A primeira delas concerne ao escopo da expressão "a respeito do que é e do que veio a ser". Se ele é apenas "é necessário a afirmação ou a negação ser verdadeira ou falsa", então o que as outras três cláusulas da sentença afirmam dos enunciados a respeito dos universais tomados universalmente, dos enunciados a respeito dos singulares e dos enunciados a respeito dos universais não tomados universalmente, elas o afirmam sem nenhuma restrição temporal. Se ele inclui também essas três cláusulas, porém, elas o afirmam apenas a respeito de enunciados sobre o presente e o passado.

Ora, dado que a sentença [5] diz que não vale para os enunciados "a respeito dos singulares que estão por vir a ser" precisamente o que a cláusula [3] diz que vale para os enunciados "a respeito dos singulares", o princípio de caridade obriga-nos a adotar o segundo modo de resolução da ambiguidade. Seria logicamente escandaloso que a cláusula [3] não estivesse incluída no escopo de "A respeito do que é e do que veio a ser" e seria, no mínimo, gramaticalmente bizarro que ela, mas não as cláusulas [2] e [4], estivesse nele incluída.

Portanto, deve-se concluir que o trecho diz não valer para os enunciados sobre singulares que estão por vir a ser algo que vale para enunciados sobre o presente e o passado, e diz que, no domínio dos enunciados sobre o presente e o passado, algo que 
vale para aqueles sobre universais tomados universalmente, assim como para aqueles sobre singulares, não vale para aqueles sobre universais não tomados universalmente. ${ }^{4}$

No entanto, o que o trecho diz não valer para os enunciados sobre singulares que estão por vir a ser? A resposta a essa questão depende de como se resolvam duas outras ambiguidades gramaticais.

Uma delas concerne ao escopo da expressão modal "é necessário". Pode-se tomálo como sendo a cláusula disjuntiva "ser verdadeira ou falsa" e a conjuntiva "ser uma verdadeira e a outra falsa". Nesse caso, o trecho diz que a lei de bivalência e a lei de distribuição valem necessariamente para os enunciados sobre o presente e o passado (com uma exceção, que, de fato, veremos ser apenas aparente), mas não para os enunciados sobre o futuro. Essa é a interpretação tradicional.

No entanto, pode-se também tomá-lo como sendo cada uma das partes dessa cláusula disjuntiva e cada uma das partes dessa cláusula conjuntiva (de modo menos natural em português do que no grego clássico, em que os padrões de ordenação das palavras nas sentenças são mais flexíveis, e ainda mais natural no grego elíptico do texto aristotélico). Nesse caso, o trecho diz que, a respeito do presente e do passado, mas não do futuro, toda afirmação ou negação é necessariamente verdadeira ou necessariamente falsa e, com uma (aparente) exceção, sempre uma é necessariamente verdadeira e a outra necessariamente falsa.

Sem ainda levar em conta a totalidade do capítulo, há razões que favorecem a primeira dessas alternativas. Em primeiro lugar, sua adoção põe o capítulo em linha de continuidade com os dois anteriores. No capítulo 7, é inquestionável que Aristóteles, sem mencionar a distinção entre enunciados sobre o presente, o passado e o futuro, estabelece que, em todo par de contraditórios, um dos membros é verdadeiro e o outro falso, com uma (aparente) exceção. Isso vale, diz ele, para os enunciados sobre universais tomados universalmente (como "todo homem é branco", "nem todo homem é branco", "nenhum homem é branco", "algum homem é branco") e sobre singulares (como "Sócrates é branco"), mas não para os enunciados sobre universais não tomados universalmente (como "homem é branco" e "homem não é branco"), enunciados em que o sujeito

\footnotetext{
${ }^{4}$ No entanto, veremos que essa leitura do trecho, se não encontra nele a tese de que afirmações e negações a respeito de universais tomados universalmente sejam sempre verdadeiros ou falsos, qualquer que seja sua referência temporal, também não exclui a hipótese de que Aristóteles a adote; cf. seção 4.2.3 abaixo, in finis.
} 
gramatical é um termo geral não quantificado. É inquestionável que, no capítulo 7, o que está em questão é a relação não modalizada entre o que Aristóteles chama de contraditórios e os valores de verdade.

Dos contraditórios sobre o universal tomado universalmente, é necessário um ou outro ser verdadeiro ou falso, assim como sobre os singulares; por exemplo, Sócrates é branco - Sócrates não é branco. No entanto, sobre o universal não tomado universalmente, nem sempre um é verdadeiro e o outro falso. Pois é verdadeiro dizer ao mesmo tempo que homem é branco e que homem não é branco (...). (De Interpretatione 7, 17b26-32)

O capítulo 8 introduz inquestionavelmente o que, para Aristóteles, seria uma segunda exceção à tese estabelecida no capítulo anterior: uma espécie de enunciado predicativo que aparentemente veicula uma só afirmação, mas que, na verdade, veicularia mais de uma. Na interpretação tradicional, o capítulo 9 introduz mais uma exceção à mesma tese. Precisamente o que o capítulo 7 afirma valer, com uma (aparente) exceção, para diferentes tipos de contraditórios, sem alusão a suas referências temporais, o trecho inicial do capítulo 9 afirma valer, com essa mesma (aparente) exceção, para esses mesmos tipos, no caso dos enunciados sobre o presente e o passado, mas não universalmente no caso dos enunciados sobre o futuro.

Outra razão que favorece o primeiro modo de resolução da ambiguidade é o fato de que a primeira sentença da segunda parte do capítulo será introduzida por uma conjunção explicativa, sendo plausível que essa sentença inicie um argumento em favor da tese proposta na primeira parte. Esse argumento é inquestionavelmente uma redução ao absurdo e a hipótese dessa redução é inquestionavelmente o antecedente do condicional introduzido por aquela conjunção explicativa, de modo que esse antecedente é plausivelmente o que a tese proposta na primeira parte nega. Ora, esse antecedente é "toda afirmação ou negação é verdadeira ou falsa", ou seja, a lei universal de bivalência, formulada sem a intervenção de nenhum termo modal. Se a segunda alternativa fosse a correta, seria de esperar que o antecedente do condicional incluísse, ainda que ambiguamente, o termo "necessário" ou algo equivalente.

Finalmente, outra ambiguidade concerne à referência do anafórico "assim", que pode ser tanto a sentença "é necessário a afirmação ou a negação ser verdadeira ou falsa" quanto a sentença "é necessário sempre ser uma verdadeira e a outra falsa". À primeira vista, Aristóteles não as considera equivalentes, pois afirma que, no domínio dos enunciados sobre o presente e o passado, a primeira é universalmente verdadeira, enquanto a segunda comporta exceções. No entanto, pode-se mostrar que, tomando-se o 
termo "negação" em uma acepção que merece ser chamada lógica, que é a única acepção em que ocorre no argumento da batalha naval, essas exceções são apenas aparentes.

Com efeito, Aristóteles parece admitir que a lei lógica de distribuição não é irrestritamente válida sequer para os enunciados sobre o presente e o passado. No entanto, essa admissão é apenas verbal, pois, no trecho inicial do capítulo 9 e nos capítulos 7 e 8, os termos "negação" e "contraditórios" não são empregados em sua acepção lógica, aquela em que Aristóteles os emprega, por exemplo, nas formulações do princípio de não contradição e seus corolários.

$\mathrm{Na}$ acepção lógica, a negação de um enunciado é o enunciado que diz não ser o caso precisamente aquilo que o primeiro diz ser o caso, nas condições estritas de validade do princípio de não contradição especificadas em Metafísica IV 3: "ao mesmo tempo, sob o mesmo aspecto e com todas as demais ressalvas que se possam adicionar no caso

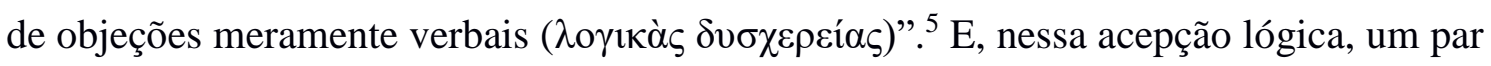
de contraditórios é o par constituído por uma afirmação e sua negação, assim entendida.

É nessa acepção que os termos são empregados em Metafísica IV, onde Aristóteles expressamente rejeita, com base no princípio de não contradição, aquilo que literalmente admite no De Interpretatione: a possibilidade de que a verdade de uma afirmação não seja equivalente à falsidade de sua negação.

Além disso, se sempre que a afirmação é verdadeira, a negação é falsa, e caso esta seja verdadeira, a afirmação é falsa, não é possível afirmar e negar verdadeiramente a mesma coisa ao mesmo tempo. (Metafísica IV 3, 1008a34-b1)

Se afirmar o verdadeiro nada mais é que negar o falso, é impossível que tudo seja falso. (Metafísica IV 8, 1012b8-10)

Essa possibilidade é também excluída nas Categorias, onde a lei de distribuição é formulada sem nenhuma restrição:

O que quer que se oponha como afirmação e negação, é evidente que não se opõe de nenhuma das maneiras antes mencionadas, pois apenas nesse caso é necessário sempre ser uma verdadeira e a outra falsa. (Categorias 10, 13a37-b3)

Ora, é evidente que não é nessa acepção lógica que os termos "negação" e "contraditórios" ocorrem nos capítulos 7, 8 e no trecho inicial do capítulo 9 do De Interpretatione. Isso não significa, porém, que eles ali ocorram em alguma outra acepção determinada. Na verdade, eles ali ocorrem em uma acepção indeterminada, contaminada

\footnotetext{
${ }^{5}$ Metafísica IV 3, 1005b19-22.
} 
pela indeterminação do estatuto semântico que, nesses textos, Aristóteles confere aos enunciados a respeito de universais não tomados universalmente - enunciados que, em

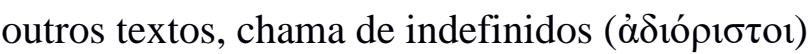

Como no De Interpretatione, também nos Primeiros Analíticos os enunciados indefinidos são agrupados em uma classe à parte, ao lado dos universais e particulares. No entanto, ali eles não são assim considerados quando se trata de classificar as figuras e modos do silogismo, sendo então tratados como logicamente equivalentes aos particulares.

Também é claro que um indefinido, posto no lugar de um afirmativo particular, produzirá o mesmo silogismo em todas as figuras. (Primeiros Analíticos I 7, 29a27-29)

Nos Tópicos, a equivalência entre indefinidos e particulares é simplesmente pressuposta e, embora sem usar as palavras "negação" e "contradição", Aristóteles claramente defende a ideia de que enunciados indefinidos são refutados - e, portanto, negados e contraditos - por enunciados universais, e não por particulares ou indefinidos.

Se o que se põe em questão é indefinido, pode-se derrubá-lo de uma só maneira, como quando se assevera que prazer é bom ou não é bom, sem nenhuma outra determinação. Pois, caso se tenha asseverado que algum prazer é bom, deve-se provar universalmente que nenhum é, se há que rebater o que foi proposto. Do mesmo modo, caso se tenha asseverado que algum prazer não é bom, deve-se provar universalmente que todos o são. Não se pode rebater de outra maneira. Pois, caso se tenha provado que algum prazer não é bom ou é bom, ainda não se terá rebatido o que foi proposto. (Tópicos III 6, 120a6-14)

Por um lado, parece plausível que, também no De Interpretatione, Aristóteles entenda que as condições de verdade de "homem é branco" e "homem não é branco" sejam, respectivamente, que algum homem seja branco e algum homem não seja branco. Por outro lado, ali ele não os equipara logicamente a enunciados particulares, mas tampouco explica ou justifica sua pretensa singularidade lógica. Consequentemente, tampouco explica ou justifica a tese, formulada no capítulo 7 e implicitamente retomada no trecho inicial do capítulo 9, de que a negação de uma afirmação indefinida é a negação indefinida de mesmo sujeito e mesmo predicado gramaticais. Mais ainda, tampouco define claramente os critérios de aplicação do termo "negação" por meio dos quais essa tese poderia ser explicada e justificada, o que é o mesmo que dizer que em nenhum momento define claramente a acepção em que esse termo é empregado na formulação da tese.

No capítulo 7, Aristóteles postula que toda afirmação tem uma única negação, que 
"deve negar precisamente o mesmo que a afirmação afirma, e a respeito do mesmo". 6 Essa fórmula é ambígua. Ela permite que se tome, como negação de "todo homem é branco": (a) seja "nenhum é homem é branco", que nega do universal homem tomado universalmente o mesmo que a afirmação afirma do universal homem tomado universalmente; (b) seja "algum homem não é branco", que nega do universal homem o que a afirmação afirma desse universal, a saber, que o branco está presente em todos os seus casos. Analogamente, ela permite que se tome, como negação de "homem é branco": (a) seja "homem não é branco", que nega do universal homem tomado indefinidamente o mesmo que a afirmação afirma do universal homem tomado indefinidamente; (b) seja "nenhum homem é branco", que nega do universal homem o que a afirmação afirma desse universal, a saber, que o branco está presente em um número indefinido de seus casos.

O segundo modo de aplicação da fórmula, que faz justiça à acepção logicamente estrita em que o termo "negação" é utilizado em Metafísica IV, fundamenta a definição, em De Interpretatione 7, do que deve contar como negação de uma afirmação sobre um universal tomado universalmente. No entanto, é o primeiro modo de sua aplicação, favorecido pela estrutura gramatical dos enunciados, que fundamenta, logo em seguida, a definição do que deve contar como negação de uma afirmação sobre um universal tomado não universalmente. Portanto, é o primeiro modo de aplicação que fundamenta a caracterização dos enunciados dessa espécie como exceções à lei de distribuição.

Sendo assim, tudo indica estarmos diante de uma daquelas situações extremas em que o princípio de caridade deve se aplicar cum grano salis. Tudo indica que a ambiguidade da fórmula que pretende definir o conceito de negação no De Interpretatione é o que permite a Aristóteles ali empregar os termos "negação" e "contraditórios" em uma acepção vaga, fruto da justaposição eclética de critérios lógicos e gramaticais de aplicação. Portanto, apenas aparentemente Aristóteles ali apresenta os enunciados indefinidos como exceções à lei lógica de distribuição.

$\mathrm{Na}$ medida em que a admissão literal dessa aparente exceção não interfere em nenhum passo da argumentação conduzida em De Interpretatione 9, pode-se entender que, para todos os efeitos lógicos, o trecho inicial do capítulo afirma a validade irrestrita da lei de distribuição no domínio dos enunciados sobre o presente e o passado. Ora, o princípio de não contradição assegura imediatamente a equivalência entre a lei de bivalência e a lei lógica de distribuição, de modo que a ambiguidade concernente à

\footnotetext{
${ }^{6}$ De Interpretatione 7, 17b39-40.
} 
referência do anafórico "assim" pode ser considerada doutrinariamente irrelevante. Como quer que ela se resolva, o resultado parece ser o mesmo: o trecho diz que nenhuma das duas leis, que valem irrestritamente para enunciados sobre o presente e o passado, vale para todos os enunciados sobre o futuro.

O trecho diz que nenhuma delas vale para enunciados a respeito do que está por vir a ser. Como se lê em De Generatione et Corruptione II 11, o que está por vir a ser é o que pode vir a ser e também pode não vir a ser no futuro e, por isso mesmo, não pode ser agora verdadeiro dizer que será. As leis não valem, pois, para os futuros que hoje chamamos contingentes. ${ }^{7}$

Uma dificuldade talvez insolúvel é a de compreender por que Aristóteles, entre todos os enunciados contingentes sobre o futuro, aponta expressamente, como exceções às leis de bivalência e distribuição, apenas aqueles "a respeito de singulares". À luz do pressuposto de que a distinção entre enunciados a respeito de universais e enunciados a respeito de singulares seja a distinção formal entre enunciados cujo sujeito é um termo geral, quantificado ou não, e enunciados cujo sujeito é um termo singular, é difícil compreender por que essas leis não valeriam, por exemplo, para "este manto de Aristóteles será cortado amanhã", mas deveriam valer para "algum manto de Aristóteles será cortado amanhã”. O próprio exemplo que deu nome ao argumento do capítulo, o enunciado "haverá uma batalha naval amanhã" parece equivaler ao enunciado particular "algum homem combaterá no mar amanhã".

Talvez se deva explorar a hipótese de que esse pressuposto não seja legítimo. Nessa linha exploratória, uma possibilidade seria entender que, no De Interpretatione, enunciados a respeito de universais seriam enunciados universais e particulares concernentes apenas a predicados de determinada espécie, que mais adiante definirei e chamarei de estritamente universais. Um enunciado universal ou particular concernente a um predicado de outra espécie seria, apesar de sua forma lógica, genuinamente um enunciado a respeito dos singulares que acontecessem de possuir esse predicado neste ou naquele momento. Voltarei a isso no final da seção 4.2.3.

Ou talvez correto seja o entendimento de Boécio: Aristóteles teria destacado os singulares porque eles exemplificariam melhor a tese a ser estabelecida, e não porque

\footnotetext{
${ }^{7}$ Cf. De Generatione et Corruptione, II 11, 337b4-7. Sobre a diferença entre o que será e o que está por vir a ser, mas pode não vir a ser, cf. também Parva Naturalia, 463b28-29.
} 
acreditasse que essa tese não se aplicaria também a enunciados universais e particulares. ${ }^{8}$ Felizmente, diferenças formais entre enunciados sobre o futuro não são invocadas nem pressupostas em nenhuma das etapas do argumento da batalha naval. Assim, o intérprete do argumento pode se dar ao luxo de ignorar essa dificuldade.

\section{O Argumento Indireto}

\subsection{O Argumento Determinista}

A exposição do argumento determinista pode ser decomposta em quatro partes. Na primeira, Aristóteles mostra que a lei universal de bivalência implica que, se algo acontece (não acontece) em um momento $m$, então já era verdadeiro, em um momento $m$ ' anterior a $m$, ou enunciar que aconteceria no momento $m$ ou enunciar que não aconteceria em $m$. Na segunda, mostra que, se já era verdadeiro enunciar em $m$ ' que algo aconteceria (não aconteceria) em $m$, então já era necessário em m' que viesse a acontecer (não acontecer) em $m$. Na medida em que a conclusão da primeira parte vale para qualquer momento $m$ ' anterior a $m$, Aristóteles conclui que a lei universal de bivalência implica que, se algo acontece (não acontece) em um momento $m$, então sempre foi, em certo sentido razoável, absolutamente necessário que viesse a acontecer (não acontecer) em $m$. Nas duas últimas partes, Aristóteles formula e descarta duas possíveis objeções à validade do argumento determinista.

\subsubsection{Primeira Parte}

[18a34-b5] Pois, se toda afirmação e negação é verdadeira ou falsa, também [6] tudo é necessário ser o caso ou não ser o caso. ${ }^{9}$ Pois ${ }^{10}$, se um diz que algo será e outro diz que a mesma coisa não será, evidentemente é necessário estar ou um ou outro dizendo a verdade, se toda afirmação e negação é verdadeira ou falsa. Pois, nessas situações, ambas as coisas não serão o caso ao mesmo tempo. Pois, [7] se é verdadeiro dizer que isso é branco ou que é não branco, então é necessário ser ou branco ou não branco; e [8] se é branco ou não branco, então era verdadeiro ou afirmá-lo ou negá-lo. E, [9] se não é o caso, o que se diz é falso e, [10] se o que se diz é falso, então não é

\footnotetext{
${ }^{8}$ Cf. Boécio, Segundo Comentário ao De Interpretatione, 202, 13-19.

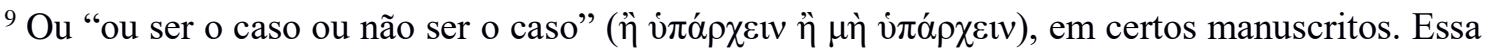
variante favorece o entendimento de que [6] é uma formulação do princípio do terceiro excluído, e não da tese determinista.

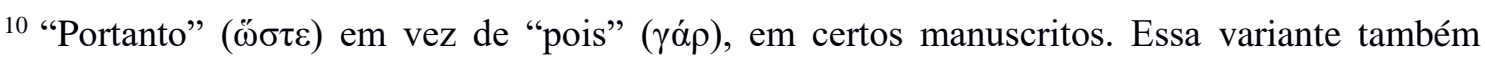
favorece o entendimento de [6] como formulação do terceiro excluído.
} 
o caso. Portanto, é necessário ser verdadeira ou a afirmação ou a negação.

A sentença [6] possui a mesma espécie de ambiguidade que afeta [1] e [2]. Se entendemos que nela o escopo do termo modal é a cláusula disjuntiva "ser o caso ou não ser o caso", ela enuncia o princípio do terceiro excluído. Se entendemos, como Boécio e Tomás de Aquino ${ }^{11}$, que o escopo do termo modal é cada uma das partes dessa cláusula separadamente, então enuncia a tese determinista: tudo necessariamente é o caso ou necessariamente não é o caso. Conforme o segundo entendimento, a sentença condicional que abre o trecho seria a antecipação do que o argumento determinista pretende concluir. À luz da reconstrução mais natural da primeira parte do argumento determinista, segundo a interpretação tradicional, esse entendimento parece preferível, embora o primeiro não resulte em uma reconstrução essencialmente diferente.

O passo crucial nessa primeira parte do argumento determinista, e nesse argumento como um todo, é o que desemboca na tese geral introduzida em [8] por meio de um exemplo: se algo é o caso em um dado momento, então já era verdadeiro o enunciado de que seria o caso nesse momento - antes mesmo, portanto, de vir a ser o caso nesse momento.

Diferentemente do que acontece no caso das definições temporalmente neutras oferecidas na Metafísica para os termos "verdadeiro" e "falso", em que não entram em linha de conta distinções temporais, no caso da tese exemplificada em [8] (assim como um pouco mais adiante, em 18b10-11), o termo "verdadeiro" remete expressamente a um predicado temporal de enunciados, um predicado que faz sentido dizer que pertence ou não a um enunciado nesse ou naquele momento. Isso evidencia que Aristóteles pretende introduzir, por meio das quatro sentenças [7]-[10], como conclusão parcial do argumento determinista, uma definição das noções temporais de verdade e falsidade. E isso, por sua vez, evidencia que a hipótese da redução é, de fato, a versão temporal da lei universal de bivalência: todo enunciado é, em todo momento, verdadeiro ou falso.

A aplicação do conceito temporal de verdade a enunciados dotados de referência temporal requer que seja temporalmente especificada a definição temporalmente genérica e neutra de verdade exposta na Metafísica. No entanto, no contexto do argumento redutivo de De Interpretatione 9, como quer que se interprete o capítulo, não se pode simplesmente pressupor que Aristóteles avalize a definição exemplificada pelas cláusulas [7] - [10],

${ }^{11}$ Cf. Boécio, Primeiro Comentário ao De Interpretatione, 108, 18-23; Tomás de Aquino, Comentário ao De Interpretatione, Lição 13, 7. 
particularmente a parte exemplificada por [8]. O que se pode de início afirmar é tão somente que, nesse contexto, essas sentenças exemplificam a definição do conceito temporal de verdade que Aristóteles encontra implicada pela hipótese da redução - a suposição da validade universal do princípio de bivalência. Com efeito, a parte da definição exemplificada por [8] será uma etapa crucial do argumento determinista, que, na interpretação tradicional, Aristóteles se verá obrigado a desqualificar a fim de esquivar a conclusão desastrosa desse argumento.

A infraestrutura conceitual que sustenta as definições aristotélicas de verdade e falsidade é apresentada em De Interpretatione 6. Ali, ela concerne expressamente aos enunciados predicativos, os únicos que interessam a Aristóteles no tratado, mas é evidente que convém a toda espécie de enunciados:

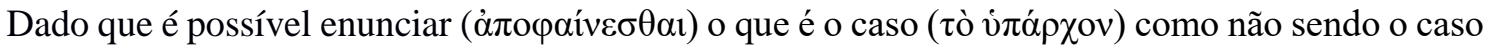

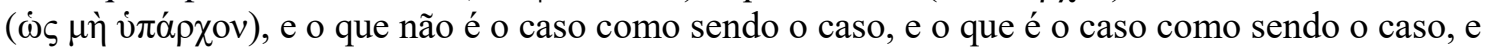
o que não é o caso como não sendo o caso, e isso igualmente no que concerne aos tempos fora do presente, pode-se então negar tudo o que se tenha afirmado, assim como afirmar tudo o que se tenha negado. (De Interpretatione 6, 17a26-31)

No plano discursivo, todo enunciado realiza, em princípio, uma entre duas alternativas exclusivas e exaustivas: a afirmação e a negação de que algo é (foi, será) o caso. No plano ontológico, o que se pode afirmar ou negar é, em princípio, a realização de uma entre duas alternativas exclusivas e exaustivas: algo ser (ter sido, vir a ser) o caso e não ser (ter sido, vir a ser) o caso. Afirmação e negação concernem às mesmas duas alternativas ontológicas. A afirmação enuncia que uma das alternativas efetivamente se realiza e, consequentemente, a outra efetivamente não se realiza. Sua negação enuncia que essa outra efetivamente se realiza e, consequentemente, aquela efetivamente não se realiza. Dadas uma afirmação e sua negação, aquilo cuja realidade uma enuncia é precisamente aquilo cuja irrealidade a outra enuncia. Parafraseando anacronicamente o jovem Wittgenstein, essa é, para Aristóteles, a forma geral do enunciado.

Essa característica essencial da estrutura lógico-semântica de todo discurso enunciativo (que o jovem Wittgenstein chamará de bipolaridade) exprime-se nos dois princípios fundamentais da lógica segundo Aristóteles. As alternativas envolvidas nessa estrutura são exclusivas: nada pode ser o caso e também não ser o caso, ser afirmado e também negado, ao mesmo tempo e sob o mesmo aspecto. É o que diz o princípio de não contradição, em suas versões ontológica e lógica. E elas são exaustivas: para aquilo que um enunciado diz ser o caso, não há, em princípio, outra possibilidade ontológica além 
de ser o caso e não ser o caso; a seu respeito, não há outra possibilidade de enunciação além de afirmar e a negar. É o que diz o princípio do terceiro excluído, em suas versões ontológica e lógica.

Essa mesma característica alicerça a definição aristotélica de verdade e falsidade, que se formula em termos das combinações possíveis entre os membros dos diferentes pares de alternativas. Se um enunciado diz que uma das alternativas ontológicas se realiza, ao invés da outra, e ela efetivamente se realiza, ao invés da outra, então o enunciado é verdadeiro, e sua negação é falsa; mas se essa outra efetivamente se realiza, ao invés daquela, então o enunciado é falso, e sua negação é verdadeira:

Isso fica claro uma vez definidos o verdadeiro e o falso; pois é falso dizer não ser o que é e ser o que não é, é verdadeiro dizer ser o que é e não ser que não é (...). (Metafísica IV 7, 1011b25-27) ${ }^{12}$

Um enunciado ser verdadeiro equivale, por definição, a realizar-se efetivamente a alternativa ontológica cuja realização ele enuncia, ao invés da outra; um enunciado ser falso equivale, por definição, a não se realizar efetivamente a alternativa ontológica cuja realização ele enuncia, e sim a outra. Se a relação entre a verdade ou falsidade de um enunciado e a realização efetiva ou não realização efetiva da alternativa ontológica cuja realização ou não realização ele enuncia é de equivalência lógica, há, porém, entre os planos discursivo e ontológico, uma assimetria causal. A realização efetiva ou a não realização efetiva da alternativa ontológica cuja realização ou não realização um enunciado enuncia é a causa necessária e suficiente de sua verdade ou falsidade, e não vice-versa:

Pois não é por pensarmos verdadeiramente que você é branco que você é branco, mas é por você ser branco que, ao dizê-lo, falamos a verdade. (Metafísica IX 10, 1051b6-9)

À primeira vista, parece tentador encontrar sem mais, na definição de verdade oferecida por Aristóteles na Metafísica, uma variante do que chamamos hoje de esquemaT de Tarski: para todo enunciado E, é verdadeiro que E se, e somente se, E. Uma das direções desse bicondicional é, à luz da definição aristotélica, irrecusável. Todo efeito pressupõe sua causa necessária, de modo que, se E é atualmente verdadeiro, daí se segue a realização efetiva da alternativa ontológica que ele privilegia, em detrimento da outra. Portanto, já que a falsidade de E implica a verdade da negação de E, são logicamente

\footnotetext{
${ }^{12}$ Cf. também Metafísica IX 10, 1051b3-5.
} 
válidos os condicionais:

[7*] se é verdadeiro que E, então $\mathrm{E}$.

[10*] se é falso que E, então não E.

No caso dos enunciados sobre o presente e o passado, também os condicionais inversos são irrecusáveis. Se E enuncia que é ou acontece agora o que efetivamente é ou acontece agora, então agora está dada a causa necessária e suficiente da verdade de E, E é verdadeiro agora. Do mesmo modo, se E enuncia que foi ou aconteceu o que efetivamente foi ou aconteceu, então agora já se deu a causa necessária e suficiente da verdade de E, E é verdadeiro agora. E assim também com respeito à falsidade.

Pode-se, contudo, dizer o mesmo a respeito dos enunciados sobre o futuro? Seria logicamente válido dizer que o enunciado "Sócrates estará no mercado amanhã" é agora verdadeiro se, e somente se, Sócrates efetivamente estiver no mercado amanhã? Ao menos não é imediatamente evidente, na hipótese de que Sócrates efetivamente esteja no mercado amanhã, que o enunciado já seja agora verdadeiro, uma vez que agora ainda não estaria dada a causa necessária e suficiente de sua verdade, a realização efetiva da alternativa ontológica que o enunciado privilegia.

Não obstante, a hipótese da validade universal da lei de bivalência impõe uma resposta positiva a essas perguntas. Admitamos essa hipótese e suponhamos que Sócrates efetivamente estará no mercado amanhã. O enunciado "Sócrates estará no mercado amanhã" não pode ser agora falso, pois, se o fosse, se deveria concluir, por [10*], que Sócrates não estará no mercado amanhã, o que contradiz a suposição inicial. Mas, não sendo agora falso, é agora verdadeiro, pois, por hipótese, todo enunciado é agora verdadeiro ou falso. Analogamente, supondo-se que Sócrates efetivamente não estará no mercado amanhã, decorre de [7*] e do princípio de não contradição que o enunciado não pode ser agora verdadeiro, de modo que, dada a hipótese inicial, deve ser agora falso.

Esse é o caminho argumentativo que leva da lei universal de bivalência à cláusula [8]. Se isso é branco agora, então esse caminho conduz à conclusão de que já era ontem verdadeiro enunciar que isso seria branco agora. Ou seja, a lei universal de bivalência, em conjunção com a definição temporalmente neutra de verdade exposta por Aristóteles na Metafísica e o princípio de não contradição, implica [8] e, de modo geral, implica a tese da retroatividade da verdade: tudo o que é o caso em um momento $m$ já era verdadeiro em todo momento anterior a $m$ enunciar que seria o caso em $m$. Sendo a verdade de um enunciado equivalente à falsidade de sua negação, a retroatividade da 
verdade implica trivialmente a retroatividade da falsidade.

Concedida a validade de [8], a conclusão da primeira parte do argumento determinista daí se segue trivialmente. Suponhamos que alguém afirme agora e alguém negue agora que algo será o caso em um tempo futuro $t$ - seja em um determinado momento futuro, seja na totalidade ou em uma parte determinada de uma determinada porção futura do tempo. Pela lei universal de bivalência, essa afirmação é agora verdadeira ou agora falsa e essa negação é agora verdadeira ou agora falsa. Mas, por [7] - [10], a verdade (falsidade) de uma afirmação sempre equivale à falsidade (verdade) de sua negação, de modo que ou a afirmação é agora verdadeira ou a negação é agora verdadeira, e, pelo princípio de não contradição, apenas uma delas é agora verdadeira.

Em suma, se uma pessoa agora prevê que algo será o caso em $t$ e outra agora prevê que não será o caso em $t$, então pelo menos uma, mas não mais que uma, diz agora a verdade.

\subsubsection{Segunda parte}

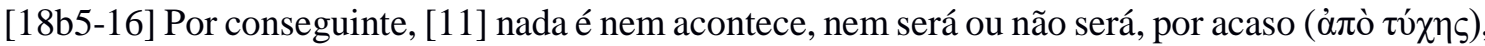

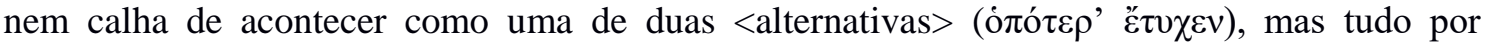
necessidade, e nada calha de acontecer como uma de duas <alternativas> (pois ou quem afirma ou quem nega diz a verdade). Pois senão teria sido possível igualmente acontecer ou não acontecer. Pois o que calha de acontecer como uma de duas <alternativas> nem é nem será assim mais do que não assim.

Além do mais, se isso agora é branco, antes era verdadeiro dizer que iria ser branco [ou: dizer "será branco"] (ő $\tau$ ह̌ $\sigma \tau \iota \iota \lambda \varepsilon v \kappa o ́ v)$, de modo que era desde sempre verdadeiro dizer que iria ser o que quer que tenha vindo a ser. Porém, se era desde sempre verdadeiro dizer que isso é ou será, então isso não pode não ser nem não vir a ser. Mas o que não pode não acontecer, é impossível não acontecer. E o que é impossível não acontecer, é necessário acontecer. Portanto, tudo o que acontecerá terá acontecido necessariamente. Logo, nada calhará de acontecer como uma de duas <alternativas>, nem será por acaso, pois, [12] se por acaso, não por necessidade.

$\mathrm{Na}$ passagem da conclusão da primeira parte do argumento determinista à conclusão final do argumento, os termos modais intervêm em um sentido temporalmente relativo. Nesse sentido, diz-se que algo é necessário, possível ou impossível não simplesmente $(\dot{\alpha} \pi \lambda \tilde{\omega} \zeta)$, absolutamente, mas relativamente a esse ou aquele momento do tempo.

Aristóteles não define o conceito de modalidade temporal, mas ele pode ser imediatamente derivado de sua definição das modalidades hipotéticas ou condicionais ( $\dot{\varepsilon} \xi$

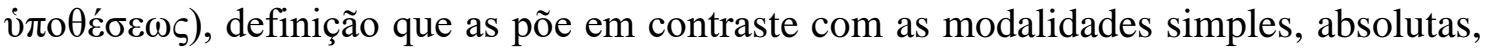
incondicionais, não qualificadas $(\dot{\alpha} \pi \lambda \tilde{\omega} \varsigma)$. 
Há, por um lado, o que é impossível e possível, falso e verdadeiro, condicionalmente (quero dizer, por exemplo, é impossível o triângulo ter dois retos, se isso, e a diagonal ser comensurável, se isso). Há, por outro lado, o que é impossível e possível, falso e verdadeiro, simplesmente. (De Caelo I 12, 281b3-8)

Considere-se o modo como Aristóteles distingue, por exemplo, necessidade condicional e incondicional. Ao contrário do que frequentemente se diz, essa distinção, embora seja traçada em termos do conceito de consequência necessária, não é a célebre distinção entre necessidade do consequente e necessidade da consequência. Ela é, como 281b3-8 evidencia, uma distinção entre duas maneiras como algo pode ser dito necessário: incondicionalmente ou sob certas condições. X é dito ser necessário sob certas condições se, e somente se, a satisfação dessas condições implica necessariamente X. A conclusão de um silogismo correto, exemplifica Aristóteles, pode não ser simplesmente necessária, mas é condicionalmente necessária, no sentido em que é necessária sob a condição de ser o caso o que as premissas dizem ser o caso. ${ }^{13}$

Dizer que algo é simplesmente necessário é dizer que está determinado a ser o caso e ponto final. Dizer que é condicionalmente necessário é dizer que está determinado a ser o caso se certas condições foram, sejam ou forem satisfeitas. Assim, o que é condicionalmente necessário está determinado a ser o caso uma vez satisfeitas as condições sob as quais é necessário que seja o caso; portanto, cabe dizer que está determinado a ser o caso a partir do momento em que essas condições estejam todas satisfeitas.

Pode-se, pois, definir a necessidade temporal em termos da necessidade condicional: é necessário em um momento $m \mathrm{X}$ ser o caso em um momento $m$ ' se, e somente se, $\mathrm{X}$ ser o caso em $m$ 'é condicionalmente necessário em relação à totalidade do que é o caso em $m$ ou já foi o caso até $m$ - e analogamente com respeito às demais modalidades, conforme suas definições cruzadas. Na medida em que, ao menos em princípio, pode já estar determinado em um dado momento que seja o caso ou aconteça algo que, em outro momento, ainda não estava determinado que seria o caso ou aconteceria, o que é necessário em um momento pode, ao menos em princípio, não ser necessário em outro momento - e analogamente com respeito às demais modalidades.

É nesse sentido temporalmente relativo que os termos modais são empregados, por exemplo, em Ética a Nicômaco VI 2, onde Aristóteles invoca expressamente a tese

\footnotetext{
${ }^{13}$ Cf. Primeiros Analíticos I 10, 30b31-40; Segundos Analíticos II 5, 91b14-17; Física II 9, 199b34ss.
} 
da necessidade do passado. Apenas o que pode acontecer e pode não acontecer, diz Aristóteles, é passível de escolha e, portanto:

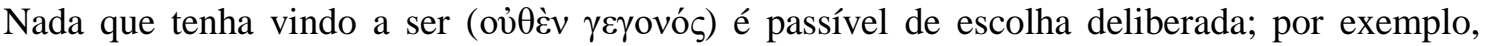
ninguém escolhe ter saqueado Troia, pois ninguém delibera sobre o que tenha vindo a ser, mas

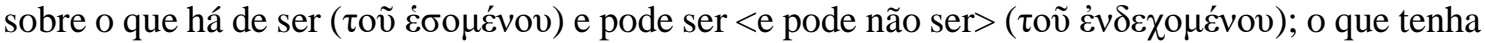
vindo a ser não pode não ter vindo a ser. Por isso, Agatão está certo:

De uma só coisa o próprio deus está privado,

fazer não ter acontecido o que já tenha sucedido.

(Ética a Nicômaco VI 2, 1139b5-11)

Porque só o contingente é passível de deliberação, apenas o que pode acontecer e pode não acontecer no futuro é passível de acontecer por escolha deliberada, já que aquilo que já tenha acontecido, é impossível que não tenha acontecido. Antes de Troia ser saqueada, escolheu-se deliberadamente saquear Troia, pois naquele momento ainda era possível tanto saquear Troia como não saquear Troia. Uma vez Troia saqueada, deixou de ser possível não se ter saqueado Troia, passou então a ser necessário que se tenha saqueado Troia. O que era contingente, passou a ser depois necessário.

É inquestionável que, nessa passagem, intervém crucialmente a tese da necessidade do passado: o que veio a ser, é agora necessário que tenha vindo a ser e, de modo geral, tudo o que foi o caso ou aconteceu antes de um momento $m$, é necessário, nesse momento $m$, que tenha sido o caso ou acontecido antes de $m$. E, ao restringir o domínio do que é passível de deliberação ao que será o caso e acontecerá no futuro, em virtude do fato de que só o contingente é passível de deliberação, a passagem ao menos sugere que, no passado e no presente, há lugar apenas para o necessário e o impossível. Assim, ela ao menos sugere que vale também a tese da necessidade do presente: o que agora é o caso ou acontece, é agora necessário que agora seja o caso ou aconteça e, de modo geral, tudo o que é o caso ou acontece em um momento $m$, é necessário em $m$ que seja o caso ou aconteça em $m$.

A conjunção das teses da necessidade do passado e do presente é explicitada em uma passagem da Retórica, que também faz da contingência um apanágio de acontecimentos futuros. Nela, Aristóteles recorre indiferentemente às formas do perfeito ( $\gamma \varepsilon \gamma o v o ́ \varsigma$ ) e do presente (őv $\tau \alpha$ ) para denotar o que, em contraste com os estados de coisas e acontecimentos futuros, só comporta a necessidade, e recorre à forma do aoristo

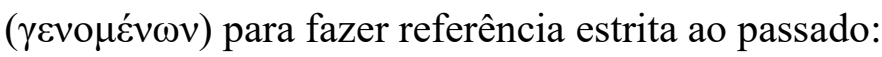

Exemplos convêm aos discursos deliberativos, enquanto entimemas convêm aos forenses. Aqueles tratam do que está por vir a ser ( $\tau$ ò $\mu \varepsilon ́ \lambda \lambda o v)$, de modo que devem buscar exemplos no 


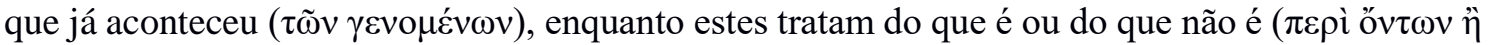

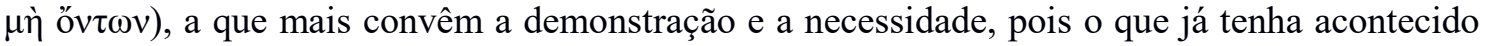

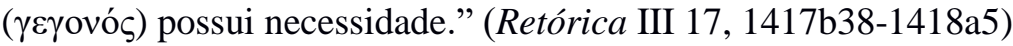

De todo modo, a tese da necessidade do presente é expressamente enunciada por Aristóteles na parte final de De Interpretatione 9:

É decerto necessário o que é ser, quando é, e o que não é não ser, quando não é. No entanto, não é necessário ser tudo o que é, nem não ser tudo o que não é. Pois não é o mesmo tudo o que é ser por necessidade, quando é, e ser por necessidade simplesmente, e assim também no que concerne ao que não é. (De Interpretatione 9,19a23-27)

De fato, a necessidade do presente nada mais é que um corolário imediato do princípio de não contradição. Dizer que é necessário em um momento $m$ que $\mathrm{X}$ seja $\mathrm{o}$ caso em um momento $m$ ' é dizer que a conjunção de tudo o que seja o caso e já tenha vindo a ser o caso em $m$ determina que $\mathrm{X}$ seja o caso em $m$ '. Ora, se $\mathrm{X}$ é o caso em $m$, então, pelo princípio de não contradição, considerando-se $m$ ' idêntico a $m$, é impossível em $m$ que $\mathrm{X}$ não seja o caso em $m$, é necessário que $\mathrm{X}$ seja o caso em $m$. Se $\mathrm{X}$ é o caso em $m$, então o conjunto do que é o caso em $m$ implica necessariamente que $\mathrm{X}$ seja o caso em $m$, é necessário em $m$ que $X$ seja o caso em $m$.

As teses da necessidade do passado e do presente são duas das premissas modais implícitas empregadas por Aristóteles na passagem da conclusão da primeira parte do argumento determinista à conclusão da segunda parte, a conclusão final do argumento. Uma terceira é uma lei modal elementar: "o que se segue do necessário é necessário". ${ }^{14}$

Se está determinado que $\mathrm{X}$ é o caso e $\mathrm{X}$ ser o caso determina que $\mathrm{Y}$ é o caso, então está determinado que $\mathrm{Y}$ é o caso. Essa lei é trivialmente equivalente a outra, a que Aristóteles frequentemente recorre ao tratar da natureza do possível: do possível não se segue o impossível.

Primeiramente, é preciso dizer que, se, A sendo o caso, é necessário que B seja o caso, então, A sendo possível, B será necessariamente também possível. (Primeiros Analíticos I 15, 34a5-7) ${ }^{15}$

Voltemos então à exposição do argumento. Suponhamos que, em um momento $m$ ', alguém afirme que $\mathrm{X}$ acontecerá em $m$ e alguém o negue. A primeira parte do argumento determinista estabelece que ou a afirmação ou a negação é verdadeira em $m^{\prime}$.

\footnotetext{
${ }^{14}$ Ética a Eudemo II 6, 1223a1.

${ }^{15}$ Cf. também Metafísica XII 4, 1047b14-16; Primeiros Analíticos I 13, 32a 18-20; Primeiros Analíticos I 15, 34a22-24; Física VIII 5, 256b 10-12; De Caelo I 12, 282a1-3.
} 
Se a afirmação é verdadeira em $m$ ', disso se segue, pela necessidade do presente, ser necessário em $m$ ' que ela é verdadeira em $m$ ' e também se segue, por [7*], que $\mathrm{X}$ acontecerá em $m$. Ora, o que se segue do necessário é também necessário, de modo que, se a afirmação é verdadeira em $m$ ', então é necessário em $m$ ' que $\mathrm{X}$ aconteça em $m$. Analogamente, se a negação é verdadeira em $m$ ', então é necessário em $m$ ' que X não aconteça em $m$. Portanto, se algo acontece (não acontece) em um momento $m$, em algum momento $m$ ' anterior a $m$ já era necessário que viesse a acontecer (não acontecer) em $m$.

E mais ainda, diz Aristóteles, pelas mesmas razões se pode concluir que tudo o que acontece (não acontece) em $m$ já era necessário que viesse a acontecer (não acontecer) não apenas em algum momento anterior a $m$, mas em todo momento anterior a $m$. Isso porque, pelas mesmas razões, se pode concluir que, se $\mathrm{X}$ acontece (não acontece) em $m$, então já teria sido verdadeiro afirmar (negar), em qualquer (e não apenas em algum) momento anterior a $m$, que $\mathrm{X}$ aconteceria (não aconteceria) em $m$. Assim, pela necessidade do passado, em $m$ é impossível que não tivesse sido verdadeiro, em qualquer (e não apenas em algum) momento anterior a $m$, afirmar (negar) que $\mathrm{X}$ acontece (não acontece) em $m$.

Portanto, se todo enunciado é verdadeiro ou falso, tudo o que aconteceu, acontece e acontecerá sempre foi, é e (pode-se acrescentar, dada a necessidade do passado) sempre será necessário que tenha acontecido, aconteça ou venha a acontecer. E tudo o que não aconteceu, não acontece e não acontecerá sempre foi, é e sempre será impossível que tenha acontecido, aconteça ou venha a acontecer. Tudo sempre foi, é e sempre será necessário ou sempre foi, é e sempre será impossível.

Ora, só é relevante distinguir modalidades temporalmente absolutas e modalidades temporalmente relativas caso, ao menos em princípio, uma modalidade temporalmente relativa possa convir a algo em um momento e não em outro. Estando em princípio excluída essa possibilidade, há um sentido razoável em que se pode dizer que não há modalidades que sejam de fato temporalmente relativas. Portanto, há um sentido razoável em que se pode dizer que, admitida a lei universal de bivalência, deve-se concluir que tudo o que acontece (não acontece), é absolutamente necessário que aconteça (não aconteça) e [11] nada é nem acontece, nem será ou não será, por acaso, nem calha de acontecer como uma de duas alternativas. ${ }^{16}$

\footnotetext{
${ }^{16}$ As teses da necessidade do presente e do passado estão a tal ponto enraizadas em nosso senso comum que pode passar despercebida a necessidade do recurso a elas para que a última etapa do argumento determinista se configure como uma inferência formalmente válida. Sem a intervenção
} 
Como entender o alcance da sentença [11]? Em Primeiros Analíticos I 13, Aristóteles distingue duas espécies de contingência. Nesse contexto, as modalidades afetam diretamente o que chamo de estados de coisas e conexões predicativas.

Chamo de estado de coisas aquilo que faz sentido enunciar que ocorre (no sentido amplo de ser um fato real) em certo momento e não em outro, ou durante certo intervalo de tempo e não durante outro (no caso de processos, como, por exemplo, Sócrates ir de casa ao mercado). Para evitar complicações técnicas irrelevantes no contexto da análise de De Interpretatione 9, considerarei apenas estados de coisas que faz sentido dizer que ocorrem em um momento - por exemplo, Sócrates estar no mercado, Édipo ver, Sócrates não estar em Esparta, um determinado manto estar sendo cortado, Sócrates estar indo de casa ao mercado, estar se travando uma batalha naval.

Dizemos que, em um momento $m$, um estado de coisas é possível se, e somente se, é possível em $m$ ocorrer em $m$ ou depois de $m$; é impossível se, e somente se, é impossível em $m$ ocorrer em $m$ ou depois de $m$; é necessário se, e somente se, é necessário em $m$ ocorrer em $m$ e em todo momento posterior a $m$; é contingente em $m$ se, e somente se, não é nem necessário nem impossível em $m$. Um estado de coisas é absolutamente possível (impossível, necessário, contingente) se, e somente se, é sempre possível (impossível, necessário, contingente). ${ }^{17}$

Assim, antes de furar os próprios olhos, era um estado de coisas possível Édipo ver, e esse estado de coisas era possível, ainda que não real, mesmo enquanto Édipo dormia ou tinha os olhos vendados, pois era então possível que Édipo visse após despertar ou ser-lhe retirada a venda. A partir do momento em que Édipo furou os próprios olhos, o estado de coisas passou a ser impossível, passou a ser impossível Édipo ver, pois passou a estar determinado que nunca mais veria, passou a ser impossível que visse, nesse momento ou no futuro. E, ao menos segundo Aristóteles, é absolutamente necessário a

das premissas modais implícitas, essa etapa envolveria inferir, de uma implicação necessária (a verdade de $\mathrm{E}$ implica necessariamente $\mathrm{E}$ ) e do antecedente não modalizado dessa implicação (E é verdadeiro), a necessidade do consequente (é necessário que E) - inferência trivialmente inválida. A necessidade do consequente infere-se validamente da implicação necessária e da necessidade do antecedente (E é necessariamente verdadeiro), que, no caso, apenas a necessidade do presente e do passado pode garantir.

${ }^{17}$ Sobre a adesão de Aristóteles a essa maneira de definir o resultado da aplicação das modalidades aléticas temporais aos estados de coisas em termos do resultado de sua aplicação a ocorrências e não ocorrências desses estados de coisas em momentos determinados, cf. De Caelo I 12, 281b14-18, 283b13-14. 
Lua mover-se, é absolutamente impossível o Sol perecer, é absolutamente possível e contingente travar-se uma batalha naval. ${ }^{18}$

O que chamo de conexões predicativas, Aristóteles exprime tipicamente por meio de sentenças indefinidas, da forma, superficial ou profunda, "F é (virá a ser) G” ou, mais naturalmente em português, "Fs são (virão a ser) Gs: "homens são racionais", “corpos celestes movem-se", "homens encanecerão", "cães são alados”, "pessoas que escavam a terra encontrarão tesouros". Quando exprimem conexões predicativas, sentenças indefinidas não veiculam enunciados, mas são utilizadas em enunciados como escopos de operadores modais e quantificadores temporais: "corpos celestes movem-se necessariamente", "sempre homens são animais", "no mais das vezes homens encanecerão", "é impossível cães serem racionais", "raramente pessoas que escavam a terra encontrarão tesouros".

Admitamos, com Aristóteles, que o tempo é infinito. Podemos então distinguir três tipos de porções do tempo: porções inteiramente fechadas, que começam em um momento determinado e terminam em um momento determinado; porções abertas na direção do futuro, que começam em um momento determinado e nunca terminarão; e porções abertas na direção do passado, que terminam em um momento determinado e nunca começaram.

Uma conexão predicativa é especificada por um par ordenado de predicados e por dizer respeito apenas ao presente ou também ao futuro. ${ }^{19}$ Dizemos ordinariamente, de maneira um tanto vaga, que, dados predicados F e G, sempre Fs são (virão a ser) Gs se, e somente se, em alguns momentos há Fs e, em cada momento, o que quer que nesse momento seja F é (virá a ser) G; nunca Fs são (virão a ser) Gs se, e somente se, em cada

\footnotetext{
${ }^{18}$ Cabe observar que a existência de estados de coisas contingentes não afronta o determinismo. Nada impede que um estado de coisas que possa ocorrer no futuro e possa não ocorrer no futuro esteja desde sempre determinado tanto a ocorrer no futuro, no exato momento em que ocorrer, quanto a não ocorrer no futuro, no exato momento em que não ocorrer. É dessa espécie, por exemplo, na cosmologia aristotélica, o estado de coisas que consiste em estar a Lua passando por um determinado lugar do céu. O que afronta o determinismo é a tese, defendida por Aristóteles em 19a7-22, de que há estados de coisas que não ocorrem agora e podem ocorrer no futuro, mas também podem nunca ocorrer. $\mathrm{O}$ que afronta o determinismo é a negação do princípio de plenitude, em sua versão mais forte. O mesmo vale para o que chamarei, logo abaixo, de conexões predicativas.

${ }^{19}$ Conexões predicativas podem dizer respeito ao futuro de modo indeterminado (por exemplo: homens morrerão) ou a uma porção determinada do futuro (por exemplo: pessoas febris que tomam hidromel estarão curadas da febre no dia seguinte). Por simplicidade, considerarei apenas as conexões do primeiro tipo.
} 
momento, o que quer que nesse momento seja $\mathrm{F}$ não é (não virá a ser) G; às vezes Fs são Gs se, e somente se, em algum momento algo que é F é (virá a ser) G, mas nem sempre. O domínio dos quantificadores temporais pode ser uma porção do tempo, fechada ou aberta, ou a totalidade do tempo.

Dados predicados F e G, diz-se que é necessário em um momento $m$ Fs serem (virem a ser) Gs se, e somente se, é necessário em $m$ que, em todo momento $m$ ' não anterior a $m$, o que quer que em $m$ ' seja F seja (venha a ser) G; é impossível em um momento $m$ Fs serem (virem a ser) Gs se, e somente se, é impossível que, em algum momento $m$ ' não anterior a $m$, algo que em $m$ ' seja F seja (venha a ser) G; é possível em $m$ Fs serem (virem a ser) Gs se, e somente se, não é impossível em $m$ Fs serem (virem a ser) Gs; é contingente em $m$ Fs serem (virem a ser) Gs se, e somente se, não é necessário nem impossível em $m$ 'Fs serem (ou virem a ser) Gs. É absolutamente necessário (possível, impossível, contingente) Fs serem Gs se, e somente se, em todo momento é necessário (possível, impossível, contingente) Fs serem Gs.

Se sempre Fs são (virão a ser) Gs, direi que a conexão predicativa expressa por "Fs são (virão a ser) Gs" ocorre sempre. Defino analogamente o que é, para uma conexão predicativa, nunca ocorrer e ocorrer às vezes. Se é necessário Fs serem (virem a ser) Gs, direi ser necessário que a conexão predicativa ocorra. Defino analogamente o que é, para uma conexão predicativa, ser impossível, possível e contingente que ocorra.

Uma ocorrência, em um dado momento $m$, de um estado de coisas que consiste em ser também G algo que, nesse momento, é F, direi que é uma ocorrência da conexão predicativa expressa por "Fs são Gs"; uma ocorrência, em um dado momento $m$, de um estado de coisas que consiste em ser $\mathrm{G}$ algo que, em um momento anterior, foi $\mathrm{F}$, direi que é uma ocorrência da conexão predicativa expressa por "Fs virão a ser Gs". Chamarei esses estados de coisas de exemplares dessas conexões predicativas no momento $m$.

Há conexões predicativas que ocorrem sempre, há aquelas que nunca ocorrem e há aquelas que ocorrem às vezes. Na classe das que ocorrem às vezes, Aristóteles delimita

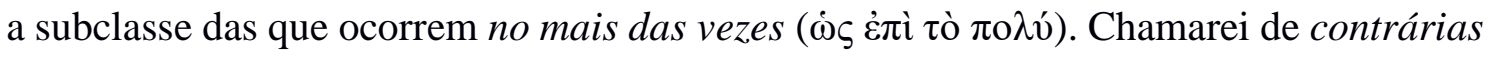
as conexões predicativas expressas por "Fs são (virão a ser) Gs" e "Fs são (virão a ser)

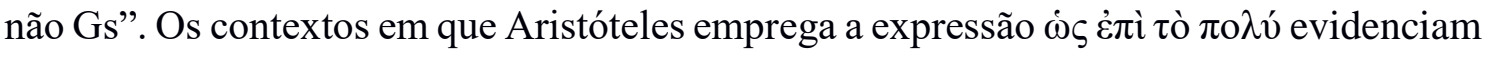
que, com ela, pretende caracterizar o que ordinariamente dizemos, de maneira certamente vaga, que ocorre muito mais frequentemente do que seu contrário, mas nem sempre. $\mathrm{O}$ sentido em que o dizemos, podemos defini-lo, também vagamente, do seguinte modo.

Dados predicados $\mathrm{F}$ e $\mathrm{G}$, dizemos que, relativamente a uma porção fechada do 
tempo $t$, no mais das vezes Fs são (virão a ser) Gs se, e somente se a grande maioria das coisas que são Fs em $t$, mas não todas, são (virão a ser) Gs em $t$. Relativamente a uma porção aberta do tempo na direção do futuro $t$ (ou à totalidade do tempo), dizemos que no mais das vezes Fs são (virão a ser) Gs se, e somente se, para qualquer momento $m$ em $t$ (ou na totalidade do tempo), existe um momento $m$ ' posterior a $m$ tal que, relativamente a toda porção fechada do tempo que começa em $m$ e termina em algum momento posterior a $m$ ', no mais das vezes Fs são (virão a ser) Gs. ${ }^{20}$

Do mesmo modo, dizemos (como Aristóteles) que, relativamente a uma porção do tempo $t$ (ou à totalidade do tempo), uma conexão predicativa ocorre raramente

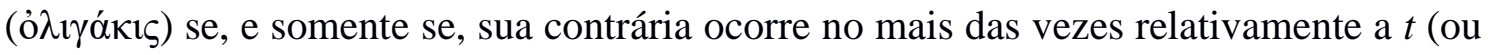
à totalidade do tempo). E na classe das conexões predicativas que ocorrem às vezes, há ainda aquelas que não ocorrem nem no mais das vezes nem raramente, ou seja, nem muito mais nem muito menos frequentemente que suas contrárias.

Em Primeiros Analíticos I 13, Aristóteles observa que conexões predicativas contingentes não o são todas do mesmo modo:

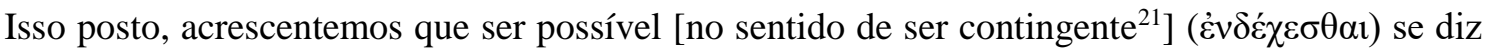
de dois modos. De um modo, <é possível> o que acontece no mais das vezes e é lacunarmente

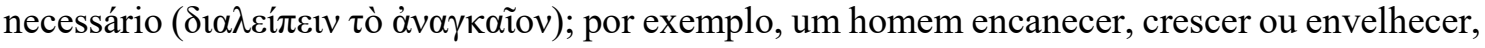

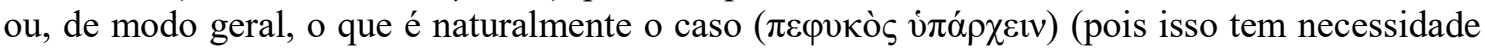
descontínua, dado que um homem não existe para sempre, mas, existindo, um homem é essas coisas ou necessariamente ou no mais das vezes). Do outro modo, é <possível> o indeterminado, o que pode tanto ser quanto não ser; por exemplo, um animal andar ou um terremoto acontecer enquanto um animal anda, ou, de modo geral, o que acontece por acaso; pois nada faz

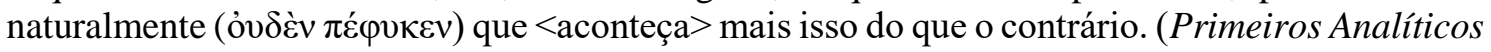
I 13, 32b4-13)

Há, portanto, para Aristóteles, dois graus de contingência que podem convir diretamente a conexões predicativas, mas indiretamente também a seus exemplares e suas ocorrências em momentos determinados. Há uma espécie de contingência que é próxima da necessidade. Aristóteles caracteriza-a como uma necessidade lacunar, descontínua, passível de ser ocasionalmente transgredida por impedimentos acidentais ao exercício das capacidades causais naturais das coisas envolvidas nos exemplares dessas conexões

\footnotetext{
${ }^{20}$ A conformidade dessa definição a nosso uso ordinário do vocabulário frequencial ficará evidente na seção 4.2.1 abaixo.

${ }^{21}$ Sobre a equivocidade de "ser possível" ( $\left.\dot{\varepsilon} v \delta \varepsilon ́ \chi \varepsilon \sigma \theta \alpha \imath\right)$ e "possível” ( $\left.\dot{\varepsilon} v \delta \varepsilon \chi o ́ \mu \varepsilon v o v\right)$, que, segundo Aristóteles, podem se aplicar ao que não é nem necessário nem impossível (ou seja, apenas ao que chamamos de contingente), mas podem também se aplicar a tudo o que não é impossível, de modo a abarcar o necessário, cf. Primeiros Analíticos I 13, 32a18-21; I 3, 25a37-39.
} 
predicativas - capacidades que, nas condições apropriadas e circunstâncias favoráveis, se exercem necessariamente, como ensina Metafísica IX 5.

Por um lado, essa espécie de contingência implica não a completa indeterminação, mas a subdeterminação causal das ocorrências das conexões predicativas a que convém. Isso porque, nas condições apropriadas e na ausência de impedimentos acidentais, isto é, impedimentos não regularmente associados ao exercício das capacidades causais das coisas envolvidas nos exemplares dessas conexões predicativas, elas são causalmente determinadas a ocorrer. Por outro lado, contudo, sendo suas ocorrências casos particulares de regularidades causais ocasionalmente infringíveis, essas conexões, uma vez preenchidas as condições apropriadas, por certo ocorrem no mais das vezes, mas ainda assim podem não ocorrer. Por extensão, é essa espécie de contingência branda que convém, em momentos determinados, aos exemplares e às ocorrências contingentes dessas conexões predicativas.

A contingência branda é a face objetiva do conceito aristotélico de probabilidade (દ̇ıKós), cuja face epistêmica é a verossimilhança ou plausibilidade, a característica dos estados de coisas e conexões predicativas que é razoável supor que, nas condições apropriadas, ocorram, tenham ocorrido ou venham a ocorrer. Na verdade, essa modalidade alética é o fundamento objetivo da plausibilidade: é plausível, ainda que incerto, supor que ocorram, tenham ocorrido ou venham a ocorrer os estados de coisas e conexões predicativas que, nas condições apropriadas, por força de sua tendência causal a ocorrer, ao invés de não ocorrer, ocorrem mais frequentemente do que não ocorrem. ${ }^{22}$

Já a contingência em grau máximo convém aos estados de coisas e conexões predicativas completamente indeterminados, aqueles cujas ocorrências não são casos particulares de regularidades causais, estritas ou lacunares, já que as capacidades causais implicadas na natureza das coisas neles envolvidas, nas condições apropriadas, não

22 Sobre a frequência como marca característica da probabilidade, cf. Retórica II 25, especialmente 1402b21: “(...) sendo o provável o que não <é> sempre, mas no mais das vezes (...)."; cf. também Primeiros Analíticos II 27, 70a3-7. Sendo a frequência suscetível de mais e menos, é natural que Aristóteles conceba também a probabilidade como suscetível de mais e menos, ou seja, como uma grandeza, no sentido amplo da expressão; cf. Retórica II 25, 1403a12: "pois o que é assim mais frequentemente é mais provável". Se Aristóteles tivesse elaborado e refinado o conceito de probabilidade objetiva, ou contingência branda, teria reconhecido que há uma escala contínua de graus de contingência. Na medida em que um estado de coisas pode ser um exemplar de mais de uma conexão predicativa em um momento determinado, Aristóteles teria também reconhecido que o grau de contingência de um estado de coisas e de suas ocorrências em um momento determinado é a resultante dos graus de contingência das conexões predicativas brandamente contingentes de que é exemplar nesse momento. 
favorecem sua ocorrência, em detrimento de sua não ocorrência. Por extensão, é essa espécie de contingência forte que convém, em momentos determinados, aos exemplares e às ocorrências contingentes, mas não brandamente contingentes, dessas conexões predicativas.

Para Aristóteles, a contingência em grau máximo é característica não apenas do que ocorre por acaso (no sentido mais amplo em que por vezes utiliza essa expressão, sentido em que ocorrer por acaso equivale a ocorrer por acidente ${ }^{23}$ ), mas também do que ocorre por escolha deliberada, seja na esfera da produção artificial, seja na esfera da ação. Com efeito, diz ele (por exemplo, em Ética a Nicômaco III 3), é passível de escolha deliberada sensata apenas o que depende de nós acontecer ou não acontecer e, portanto, não o que acontece ou não acontece por necessidade nem por natureza. ${ }^{24}$ Isso vale tanto no âmbito da ação como no da produção artificial.

Toda arte concerne ao vir a ser e preconceber tecnicamente ( $\tau \varepsilon \chi v \alpha ́ \zeta \varepsilon v v)$ é considerar como pode vir a ser o que pode tanto ser como não $\operatorname{ser}^{25}$, e cujo princípio está no produtor, e não no produto. Pois a arte não concerne ao que é ou vem a ser por necessidade ou por natureza. Pois o princípio dessas coisas está nelas mesmas. (...) De certo modo, o acaso e a arte concernem às mesmas coisas (...). (Ética a Nicômaco VI 4, 1140a10-18)

O acaso e a arte - e, podemos acrescentar, toda escolha deliberada - concernem às mesmas coisas no sentido em que concernem ao que pode acontecer e pode não acontecer, mas não acontece como resultado do exercício necessário, quando desimpedido e nas condições apropriadas, das tendências naturais das coisas envolvidas. Concernem, portanto, ao que pode acontecer e pode não acontecer com o grau máximo de contingência. É por isso que aquilo que pode acontecer por acaso pode, muitas vezes, acontecer também por escolha deliberada: ser curada uma doença usualmente fatal, seja pelas escolhas tecnicamente competentes do médico, seja pela ingestão casual de um alimento regenerador ou pela incidência casual de ações causais naturais no corpo doente;

\footnotetext{
${ }^{23}$ A expressão é utilizada nesse sentido amplo, por exemplo, em De Generatione et Corruptione II 6, 333b4-7; Ética a Nicômaco III 3, 1112a31-33; Segundos Analíticos I 30, 87b19-27.

${ }^{24}$ Cf. Ética a Nicômaco III 3, 1112a18-26

${ }^{25}$ Traduzo a frase como ocorre em um dos manuscritos, pois seu sentido me parece ser melhor articulado que o da frase que ocorre na maioria deles, que se traduziria assim: "toda arte concerne ao vir a ser, a preconceber tecnicamente e considerar como pode vir a ser o que pode tanto ser como não ser (...)".
} 
encontrar um tesouro ao se cavar a terra, seja com a intenção de encontrá-lo, seja por um feliz acaso. ${ }^{26}$

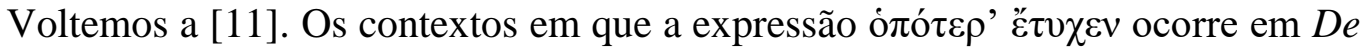
Interpretatione 9, e também em outros textos aristotélicos, evidenciam que ela se aplica a todo o domínio da contingência em grau máximo, a tudo que, sendo contingente que aconteça, não acontece por necessidade lacunar, não sendo mais provável que aconteça do que aconteça o contrário. Ela remete ao que acontece por acaso ou por acidente, no sentido definido em Metafísica VI 2 e Física II 4-6, ou seja, àquilo que acontece como resultado de interferências, distorções e conjunções acidentais, funcionalmente irrelevantes, em processos teleológicos dos quais esse resultado não é o fim próprio. $\mathrm{E}$ remete também aos efeitos das escolhas deliberadas - que desempenharão, aliás, papel crucial na redução ao absurdo da tese determinista. ${ }^{27}$

Portanto, dizer que nada acontece por acaso nem calha de acontecer como uma de duas alternativas não é literalmente dizer que nada é contingente. A ideia de que a lei universal de bivalência destrói também a contingência do que acontece no mais das vezes é apenas explicitada na sequência do capítulo (18b9, 19a19-21, 19a38-39). No entanto, para Aristóteles, a não ocorrência, nas condições apropriadas, de um estado de coisas que, nessas condições, ocorre no mais das vezes se deve sempre a distorções e interferências acidentais no processo de seu vir a ser. ${ }^{28}$ Com efeito, o que acontece no mais das vezes é

${ }^{26}$ Sobre a possibilidade de recuperação da saúde pelo exercício da arte e por acaso, cf. Retórica I 5, 1362a2-5, De Partibus Animalium I 1, 640a27-29; Metafísica VII 9, 1034a9-10, IX 7, 1049a35. A espécie de coisas que acontecem por acidente para a qual Aristóteles, em Física II 4-6,

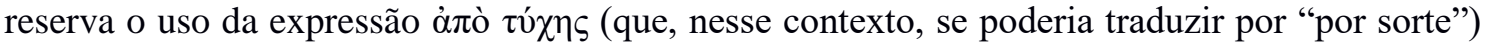

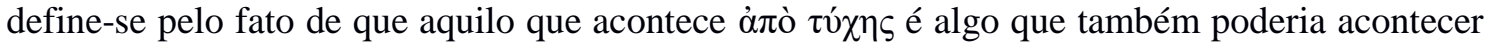
por escolha deliberada; cf. Física II 5, 197a5-8.

${ }^{27}$ Cf. De Interpretatione 9, 19a18-22; Metafísica VI 3, 1027b12-16; Categorias 10, 12b35-13a3;

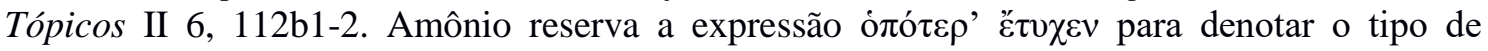
contingente em grau máximo que ocorre e não ocorre de maneira igualmente provável, em contraste com o casual e, em geral, o acidental, que ocorre excepcional e raramente, pois mais provavelmente não ocorre do que ocorre. Seria do primeiro tipo apenas o que ocorre por escolha deliberada; cf. Amônio, Comentário ao De Interpretatione, 142, 1-143,11. Essa é também a opção terminológica de Tomás de Aquino com respeito à expressão utrumlibet, que os comentadores

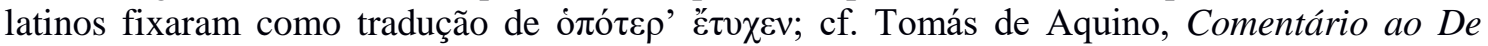
Interpretatione I, Lição 13, 9. E também a de Boécio, no Primeiro Comentário (cf. 112, 22-113, 7). No Segundo Comentário, porém, Boécio emprega utrumlibet na mesma acepção mais ampla

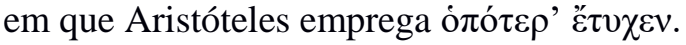

${ }^{28}$ Isso é corroborado por textos aristotélicos em que a classificação dos eventos naturais em eventos que acontecem sempre e por necessidade, eventos que acontecem no mais das vezes e eventos que acontecem por acidente ou por acaso, no sentido mais amplo da expressão, é apresentada como exaustiva. Cf. De Generatione et Corruptione II 6, 333b4-7; Ética a Nicômaco 
contingente porque, e apenas porque, sua tendência causal a acontecer pode ser casualmente (no sentido amplo) e, portanto, contingentemente, segundo [12], descontinuada. Sendo assim, se nada acontecesse acidentalmente, então também o que acontecesse mais frequentemente, quando acontecesse ou não acontecesse, aconteceria ou não aconteceria por necessidade estrita, contínua. Essa é a lição explícita de Metafísica VI 3. Portanto, dizer que nada é contingente em grau máximo equivale, no final das contas, a dizer simplesmente que nada é contingente. ${ }^{29}$

\subsubsection{Primeira Objeção e Resposta}

[18b16-25] Mas tampouco se pode dizer que nenhuma das duas é verdadeira, ou seja, que isso nem será nem não será. Pois, em primeiro lugar, sendo a afirmação falsa, a negação não seria verdadeira, e sendo essa falsa, a afirmação resultaria não ser verdadeira. E, além disso, se é verdadeiro dizer que isso é branco e grande ${ }^{30}$, então ambas as coisas devem ser o caso; mas, se devem ser o caso amanhã, serão o caso amanhã. Porém, se devem nem ser nem não ser amanhã, então não calharia de acontecer como uma de duas <alternativas>, por exemplo, uma batalha naval. A batalha naval deveria nem acontecer nem não acontecer.

A validade do argumento determinista pressupõe a verdade da conclusão de sua primeira parte: dada uma afirmação qualquer e sua negação, uma delas é verdadeira, sendo impossível serem ambas verdadeiras. Não seria, contudo, possível preservar a universalidade da lei de bivalência e evitar a conclusão determinista mediante apelo à hipótese de haver afirmações tais que nem elas nem suas respectivas negações fossem verdadeiras?

A resposta de Aristóteles é negativa. No entanto, ao contrário do que Boécio e Tomás ao menos literalmente afirmam ${ }^{31}$, essa resposta equivale à recusa não da hipótese em si mesma, mas da viabilidade lógica de sua admissão por quem admita a universalidade da lei de bivalência. De fato, os dois argumentos apresentados por Aristóteles para demonstrar a ineficácia dessa possível objeção ao argumento determinista pressupõem a validade da lei universal de bivalência. Esse pressuposto, sem

III 3, 1112a31-33; Metafísica VI 2, 1026b27-33, 1027a8-13.

${ }^{29}$ É esse, por exemplo, o entendimento de Tomás de Aquino (cf. Comentário ao De Interpretatione I, Lição 13, 9) e Al-Farabi (cf. Comentário ao De Interpretatione, 95, 1-6).

${ }^{30}$ Comparece o termo $\mu \dot{\varepsilon} \lambda \alpha v$ (negro) em alguns manuscritos, em vez de $\mu \dot{\varepsilon} \gamma \alpha$ (grande).

${ }^{31}$ Cf. Boécio, Primeiro Comentário ao De Interpretatione, 115, 1-31, e Segundo Comentário ao De Interpretatione, 214, 25-215, 26; Tomás de Aquino, Comentário ao De Interpretatione, Lição 13, 12. O grifo em "literalmente" se tornará compreensível na seção 5.2 abaixo. 
o qual ambos os argumentos não passariam de falácias grosseiras, intervém necessariamente na passagem da hipótese em causa às conclusões que evidenciariam a ineficácia da objeção, pois só ele pode justificar o passo inferencial decisivo nesses argumentos: inferir, da suposição de não serem verdadeiras nem a afirmação nem sua negação, que são ambas falsas, já que não poderiam, pressuposta a lei de bivalência, ser nem verdadeiras nem falsas.

Dado esse passo inferencial, Aristóteles pode concluir que, se nem a afirmação nem sua negação fossem verdadeiras, então a afirmação seria falsa sem que a negação fosse verdadeira e esta seria falsa sem que aquela fosse verdadeira, o que contradiz abertamente a definição do conceito lógico de negação.

Além disso, continua Aristóteles, mesmo que se admita, por amor ao argumento, que ambas fossem falsas, a conclusão determinista seria inescapável. O argumento determinista prova, a partir da lei universal de bivalência, da definição de verdade e da necessidade do presente e do passado, ser absolutamente necessário que seja o caso em um momento $m$ o que diz ser o caso em $m$ um enunciado que seja verdadeiro em um momento qualquer $m$ '. A mesma estratégia argumentativa que permite prová-lo permite também provar, substituindo-se a definição de verdade pela definição de falsidade, ser absolutamente necessário não ser o caso em um momento $m$ o que diz ser o caso em $m$ um enunciado que seja falso em um momento qualquer $m$ '.

Portanto, se é agora falso dizer que haverá uma batalha naval amanhã e também que não haverá uma batalha naval amanhã, então é agora impossível haver e impossível não haver uma batalha naval amanhã, do mesmo modo que, se é agora verdadeiro dizer que algo é branco e também que é grande, então é agora necessário ser branco e necessário ser grande. Em suma, admitida a lei universal de bivalência, se nem a afirmação nem sua negação fossem verdadeiras, então ambas diriam o impossível, nenhuma diria o contingente, de modo que a objeção nada mais é que uma manobra desesperada, logicamente absurda e praticamente ineficaz.

\subsubsection{Segunda Objeção e Resposta}

[18b33-19a6] Com efeito, nada impede que, dez mil anos atrás, alguém tenha afirmado que isso será e alguém, que não será, de modo que necessariamente será aquela dessas duas coisas que, naquele momento, tenha sido dita verdadeiramente.

E tampouco faz diferença que os contraditórios tenham sido enunciados ou não, pois é evidente que as coisas são como são, mesmo que ninguém o tenha afirmado e ninguém o tenha negado. Pois não é em virtude de se afirmar ou negar, não importa se há dez mil anos ou há quanto tempo 
que seja, que isso será ou não será. Portanto, se todo o tempo as coisas eram de um modo tal a um ou outro ser verdadeiro, então era necessário isso vir a ser e tudo o que vem a ser é sempre tal que vem a ser por necessidade. Pois o que alguém disse verdadeiramente que será não pode não vir a ser. $\mathrm{E}$ a respeito do que vem a ser, sempre era verdadeiro dizer que viria a ser.

Pressuposta a lei universal de bivalência, o argumento determinista conclui que tudo acontece e acontecerá por necessidade porque sempre foi verdadeiro afirmar, e sempre foi falso negar, que aconteceria o que agora acontece ou acontecerá no futuro. Não se poderia, contudo, objetar: e se nunca alguém já tivesse afirmado ou negado que um determinado acontecimento se daria agora ou no futuro? Ninguém haveria de duvidar que esse é o caso da maior parte dos acontecimentos presentes e futuros. Assim sendo, como poderia já ter sido verdadeira ou falsa uma afirmação ou negação que simplesmente nunca existiu? Nesse caso, portanto, nada impediria supor, sem afrontar a lei universal de bivalência, que esse acontecimento tenha se dado ou venha a se dar contingentemente.

A resposta de Aristóteles a essa objeção antecipa o cerne do argumento direto que, na parte final do capítulo, explicará porque a lei de bivalência não vale para todos os enunciados sobre o futuro. Trata-se da tese da dependência causal da verdade e falsidade dos enunciados em relação ao que as coisas realmente são e não são.

A lei universal de bivalência diz ser necessário que todo enunciado seja verdadeiro ou falso. O que ela diz ser verdadeiro ou falso não é, pois, apenas todo enunciado que aconteceu, acontece ou acontecerá de ser realmente emitido, mas também todo enunciado que possa ter sido, ser ou vir a ser emitido em um momento qualquer. Ora, a causa da verdade de um enunciado é, para Aristóteles, a realidade efetiva da alternativa de ser o caso o que ele diz ser o caso, em detrimento da alternativa de não ser o caso. Assim, se é ou seria verdadeiro em determinado momento afirmar que um estado de coisas ocorrerá no futuro, é porque nesse momento a realidade é tal que já garante a realização efetiva da alternativa de ele ocorrer no futuro, em detrimento da alternativa de não ocorrer no futuro.

Pode-se, então, concluir que, admitida a lei universal de bivalência, em qualquer momento $m$ as coisas devem realmente ser ou acontecer de modo tal a tornar verdadeiro ou falso qualquer enunciado que seja ou possa ser emitido nesse momento. No caso de um enunciado que seja ou possa ter sido emitido agora sobre o futuro, isso significa que elas devem realmente ser ou acontecer agora de modo tal a determinar ou que será o caso o que o enunciado diz que será o caso, se ele for agora verdadeiro, ou que não será o caso o que ele diz que será o caso, se ele for agora falso, não fazendo nenhuma diferença o fato 
de o enunciado ter ou não ter sido realmente emitido. Em suma, supondo-se ser necessário que todo enunciado seja verdadeiro ou falso, se algo acontecerá no futuro, então todo o tempo as coisas vêm sendo tais que sempre foi necessário que isso venha a acontecer, sendo irrelevante a questão de saber se alguém, há dez mil anos ou há quanto tempo que seja, realmente afirmou ou negou que aconteceria no futuro.

\subsection{Os Absurdos}

\subsubsection{Primeiro Absurdo: a Justificação da Preguiça}

[18b26-36] São esses, e outros similares, os absurdos que resultam se efetivamente, com respeito a toda afirmação e negação, seja a respeito de universais ditos universalmente, seja a respeito de singulares, é necessário ser um dos opostos verdadeiro e o outro falso, e se, no âmbito do que acontece, nada calha de acontecer como uma de duas <alternativas〉, mas tudo é e acontece por necessidade. Não seria preciso, então, deliberar nem se empenhar em agir ( $\pi \rho \alpha \gamma \mu \alpha \tau \varepsilon v ́ \varepsilon \sigma \theta \alpha$ ) , estimando que, se fizermos isso, isso será, se não o fizermos, isso não será. Com efeito, nada impede que, dez mil anos atrás, alguém tenha afirmado que isso será e alguém, que não será, de modo que necessariamente será aquela dessas duas coisas que, naquele momento, tenha sido dita verdadeiramente.

O trecho apresenta a segunda premissa do modus tollens por meio do qual Aristóteles concluirá que a lei de bivalência não é irrestritamente válida: o fato bruto, sensatamente indisputável, de que, no mundo sublunar, há o que acontece ou não acontece contingentemente.

A primeira premissa é a implicação estabelecida pelo argumento determinista. Ora, parece inquestionável que Aristóteles pretende formular essa primeira premissa na frase inicial desse trecho. No entanto, nessa formulação, o antecedente explícito da implicação não é a lei universal de bivalência - que é, na exposição do argumento determinista, a hipótese de redução - e sim a lei universal de distribuição. Parece, pois, inquestionável que, nesse trecho, Aristóteles trata as duas leis como trivialmente equivalentes.

A segunda premissa do modus tollens é estabelecida mediante a denúncia dos absurdos que decorrem da tese determinista, o consequente da primeira premissa. $\mathrm{O}$ mais chocante deles é a negação de uma crença que Aristóteles considera ser inabalável, por estar tacitamente implicada no modo como os agentes racionais conduzem sua vida prática: há coisas que um agente racional pode fazer com a intenção de alcançar um fim desejado, coisas que pode também não fazer, de modo que, se as fizer, o fim será alcançado; se não as fizer, não será alcançado. Para Aristóteles, a negação desse endoxon 
mina os alicerces do conceito do que se entende ser uma ação intencional e, particularmente, do conceito do que se entende ser o paradigma da ação racional: a ação deliberada.

Se tudo o que acontecerá e tudo o que não acontecerá sempre esteve determinado a acontecer e a não acontecer, argumenta Aristóteles, nada motivaria um agente racional a deliberar e empenhar-se em agir para alcançar um fim por ele desejado. A incompatibilidade entre o determinismo e a racionalidade de ações intencionais e deliberações práticas é uma consequência imediata do modo como Aristóteles, nos tratados éticos, especialmente em Ética a Nicômaco III 1-5 e Ética a Eudemo II 6-10, caracteriza os conceitos de ação intencional e voluntária, deliberação e escolha deliberada, por meio dos quais se define o que entende por ação racional.

A única razão que pode motivar um agente racional a deliberar e empenhar-se em agir com o propósito de que se realize um fim desejado é a possibilidade de que sua ação seja eficaz e relevante para a realização desse fim. Com efeito, se um agente racional, ao invés de permanecer inativo, se empenha em agir com a intenção de que um fim desejado se realize, ele o faz, enquanto agente racional, pela conjunção de duas razões.

Em primeiro lugar, ele o faz porque acredita que sua ação contribuirá causalmente para que o fim se realize, ou ao menos para aumentar o grau de probabilidade de que se realize - caso contrário, sua ação seria ineficaz. Em segundo lugar, ele o faz porque acredita que, se não agir, o fim não se realizará, ou ao menos poderá não se realizar - caso contrário, sua ação seria supérflua. A primeira razão pressupõe a crença na possibilidade de realização do fim, a segunda pressupõe a crença na possibilidade de não realização do fim. A conjunção das duas pressupõe a crença na contingência da realização do fim.

Analogamente, se um agente racional, com a intenção de que um fim desejado se realize, toma a iniciativa de deliberar se o melhor é permanecer inativo ou agir, e se é agir desta ou daquela maneira, ele o faz, enquanto agente racional, porque acredita que pode não agir e pode agir, desta ou daquela maneira, e acredita que deve escolher realizar uma dessas possibilidades: ou não agir ou agir da maneira que deliberar ser a que mais contribuirá causalmente para a realização do fim. Portanto, ele o faz, enquanto agente racional, porque acredita na contingência da realização das ações sobre as quais se trata de deliberar.

Na medida em que um agente racional apenas delibera, enquanto agente racional, sobre a realização ou não de ações que acredita poderem ser eficazes e não supérfluas para a realização do fim desejado, e na medida em que ações dessa espécie são, por 
definição, praticadas em vista de fins contingentes, um agente racional apenas delibera, enquanto agente racional, sobre o que acredita ser contingente e em vista do que acredita ser contingente. Nenhuma pessoa sensata delibera sobre o que acredita ser necessário que seja o caso ou que não seja o caso, mas apenas sobre o que acredita que dependa de sua iniciativa, como origem de uma cadeia causal, que aconteça ou não aconteça:

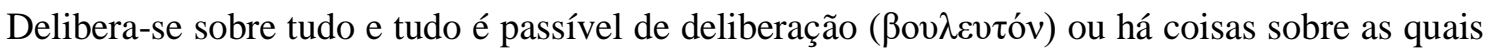
não se delibera? Ao que parece, devemos chamar de passível de deliberação aquilo sobre o que deliberaria não um tolo ou um louco, mas alguém sensato (o voṽv Ě $\chi \omega v)$. Assim, ninguém delibera sobre o que é eterno, por exemplo, sobre o cosmos e sobre serem incomensuráveis a diagonal e o lado. Mas tampouco sobre o que envolve mudança ( $\tau \tilde{\omega} v \dot{\varepsilon} v \kappa ı v \eta ́ \sigma \varepsilon \iota)$, mas acontece sempre da mesma maneira, ou por necessidade, ou ainda por natureza, ou por alguma outra causa, como os solstícios e o nascer dos astros (...). Mas deliberamos sobre o que é factível e depende de nós

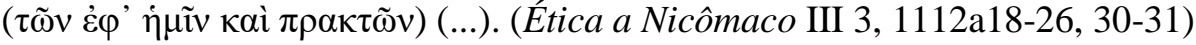

Deliberamos, porém, sobre o que aparenta poder se dar de dois modos. Pois ninguém delibera sobre o que supõe ser impossível que tenha vindo a ser, venha a ser ou seja de outro modo. Pois de nada serve. (Retórica I 2, 1357a4-7) 32 $^{32}$

Nenhuma pessoa sensata delibera sobre algo que acredita ser necessário ou impossível de acontecer, nenhuma pessoa sensata delibera sobre o necessário e o impossível senão por ignorar que seja necessário ou impossível. Portanto, na hipótese de sempre ter sido necessário que acontecerá ou que não acontecerá tudo o que acontecerá e tudo o que não acontecerá no mundo, nenhum agente que realmente acredite nisso terá razão alguma para deliberar e empenhar-se em agir com a intenção de que se realize o quer que seja, de modo que nenhum agente racional deliberará e se empenhará em agir senão por ignorância.

Suponhamos que, nessa hipótese, o agente hoje não delibere nem se empenhe em agir com a intenção de realizar um fim desejado. Se sempre foi necessário que esse fim se realizará, então ele se realizará, como resultado de uma cadeia causal que ou não incluirá nada que o agente fará (porque sempre foi necessário que não o faria), ou incluirá algo que acabará fazendo sem deliberar nem se empenhar em fazer com a intenção de alcançar o fim desejado, mas talvez por impulso irrefletido (porque sempre foi necessário que o faria). Se sempre foi necessário que o fim desejado pelo agente não se realizará, então ele não se realizará, seja por não ter o agente hoje deliberado nem se empenhado em fazer algo com a intenção de realizá-lo (porque sempre foi necessário que não o faria), seja por causa de qualquer outra coisa, mesmo que o agente hoje tenha, insensatamente,

\footnotetext{
${ }^{32}$ Cf. também Ética a Nicômaco VI 1, 1139a13-14: “(...) mas ninguém delibera sobre o que não pode se dar de outro modo."
} 
deliberado e se empenhado em agir para alcançar seu fim (porque sempre foi necessário que o faria).

Mais ainda, se sempre foi necessário que o fim não se realizará, então não cabe dizer que esse agente ocioso deveria ter hoje deliberado e se empenhado em agir para realizá-lo. Se a realização do fim sempre foi impossível e o fato de o agente hoje deliberar e empenhar-se em agir implica a realização do fim, então sempre foi impossível para o agente hoje deliberar e empenhar-se em agir, pois o impossível não se segue do possível - e é absurdo dizer que alguém deveria ter feito hoje algo que sempre foi impossível que fizesse hoje.

Assim, o modo como os textos éticos de Aristóteles estabelecem o vínculo entre deliberação, ação intencional e contingência leva Aristóteles a concluir: se a tese determinista fosse verdadeira, seria desnecessário para um agente racional dar-se ao trabalho de deliberar e agir intencionalmente, de modo que não haveria razão alguma para que, em algum momento, se desse ao trabalho de sair do estado de inatividade. Nessa medida, o argumento de Aristóteles - a exemplo daquele discutido por Cícero em $D e$ Fato XII-XIII - pode ser apropriadamente qualificado como um argumento preguiçoso. ${ }^{33}$

No entanto, esses textos éticos autorizam uma conclusão mais forte: se a tese determinista é verdadeira, então seria não apenas desnecessário deliberar e agir intencionalmente, mas também insensato, exceto no caso de desconhecimento da suposta verdade da tese. Exceto nesse caso, quem deliberasse e agisse intencionalmente estaria, para alcançar um fim, fazendo algo que, de antemão, já saberia ser ineficaz e supérfluo para alcançá-lo. Por conseguinte, pressuposta a tese determinista, apenas por ignorância ou insensatez alguém se daria ao trabalho de deliberar e agir com a intenção de realizar um desejo - conclusão suficientemente absurda para arruinar qualquer tese que a implique, direta ou indiretamente.

\footnotetext{
${ }^{33} \mathrm{O}$ correto é dizer um, e não $o$, argumento preguiçoso. O argumento discutido por Cícero tem a seguinte estrutura: se $\mathrm{X}$ está determinado a acontecer, então $\mathrm{X}$ acontecerá, quer se faça algo, quer não se faça nada; portanto, nada justifica que se faça o que quer que seja em nenhuma circunstância. A conclusão intermediária "X acontecerá, quer se faça algo, quer não se faça nada" é o alvo imediato da refutação do argumento atribuída por Cícero a Crisipo. Não é verdade, teria dito Crisipo, que, estando determinado que você convalescerá, você convalescerá, quer chame um médico, quer não chame; você convalescerá porque chamará um médico e sempre esteve determinado que convalesceria porque chamaria um médico. Essa conclusão intermediária, porém, está ausente na formulação do argumento preguiçoso aristotélico, que pode ser reconstruído, como o fiz, sem seu auxílio. Assim, a refutação de Crisipo não afeta esse argumento. Sobre o argumento aristotélico, cf. por exemplo Broadie 1986, 1987.
} 


\subsubsection{O Segundo Absurdo: o Princípio de Plenitude}

[19a7-22] Por conseguinte, se isso é impossível - pois vemos que há um princípio do que acontecerá <que opera> tanto ao se deliberar algo quanto ao se praticar alguma ação; e que, em geral, há no que nem sempre é atual o poder ser e não ser, e o que pode as duas coisas, tanto ser quanto não ser, consequentemente pode tanto vir a ser quanto não vir a ser; e para nós é evidente que muitas coisas são assim; por exemplo, é possível que este manto seja cortado e ele não será cortado, mas antes se desfará; assim como é também possível não ser cortado, pois não teria de fato antes se desfeito se não fosse realmente possível não ser cortado; isso também se aplica, portanto, a todos os outros acontecimentos que se dizem no modo dessa espécie de possibilidade - então é evidente que nem tudo é ou vem a ser por necessidade, mas há, por um lado, o que calha de acontecer como uma de duas <alternativas〉, não sendo mais verdadeira nem a afirmação nem a negação, e há também, por outro lado, o que é mais de uma maneira do que de outra, e no mais das vezes, mas também pode acontecer dessa maneira, e não daquela.

Ao deliberar e agir intencionalmente, um agente opera como um princípio, no sentido mais forte da palavra. Ele opera como origem de cadeias causais que resultam em acontecer ou não acontecer o que, antes da conclusão da ação deliberada, poderia

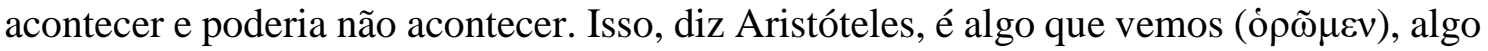
imediatamente evidente. O modo como Aristóteles esclarece as noções de deliberação e ação intencional nos textos éticos permite afirmar que se trata de algo imediatamente evidente para qualquer agente racional. Quem delibera e age intencionalmente age como se suas ações e seus fins fossem contingentes; portanto, se diz que nada é contingente, então ou é um insensato, ou apenas o diz da boca para fora, como aqueles de que fala Aristóteles em Metafísica IV 4, que dizem que o princípio de não contradição não é necessariamente verdadeiro, mas realmente não acreditam nisso, pois agem como se ele o fosse..$^{34}$

Há, portanto, o que pode ser e pode não ser, de modo que pode vir a ser e pode não vir a ser. O exemplo escolhido por Aristóteles para ilustrá-lo é historicamente significativo, pois é a negação direta da conclusão do argumento dominador. Essa conclusão é uma versão forte do princípio de plenitude, segundo a qual todo estado de coisas ou conexão predicativa que, em um dado momento, é possível, mas não ocorre nesse momento, não apenas pode ocorrer depois, mas necessariamente acabará, mais cedo ou mais tarde, por ocorrer.

Este manto ser cortado, diz Aristóteles, é agora um estado de coisas possível pois, podemos acrescentar, basta decidirmos cortá-lo e ele será cortado. No entanto, ele não está sendo cortado e pode desgastar-se antes de ser cortado - pois, podemos

\footnotetext{
${ }^{34}$ Cf. Metafisica IV 4, 1008b12-27
} 
acrescentar, basta que ninguém decida cortá-lo antes que se desgaste. É evidente para Aristóteles que há possíveis que não são reais nem nunca serão. Nem todos os estados de coisas que agora não ocorrem, mas podem vir ocorrer, necessariamente ocorrerão. Há aqueles que provavelmente ocorrerão, mas podem casualmente nunca vir a ocorrer, e há aqueles que, contingentes em grau máximo, não é mais provável ocorrerem do que nunca virem a ocorrer.

\section{O Argumento Direto}

A tese determinista segue-se da lei universal de bivalência, em conjunção com uma premissa auxiliar explícita, a definição de verdade, e outras três implícitas, as teses da necessidade do passado e do presente e a lei segundo a qual o necessário se segue do necessário. Ora, a tese determinista é absurda. Logo, por modus tollens, a lei de bivalência não é universalmente válida (assim como a lei universal de distribuição). Essa é a estrutura do argumento indireto.

O argumento direto é a transformação desse modus tollens em um modus ponens: a tese indeterminista implica, em conjunção com aquelas mesmas premissas auxiliares, que a lei de bivalência (assim como a lei de distribuição) não é universalmente válida; ora, como já se havia mostrado, a tese indeterminista é verdadeira; logo, a lei de bivalência (assim como a lei de distribuição) não é universalmente válida - embora seja universalmente válida uma versão fraca da lei, essa sim implicada pelo princípio do terceiro excluído - princípio que o argumento da batalha naval preserva incondicionalmente. E o argumento direto evidencia por que a lei de bivalência não vale universalmente: porque há futuros contingentes e a verdade ou falsidade de um enunciado depende causalmente de ser ou não o caso o que o enunciado diz ser o caso.

\subsection{Primeira Parte}

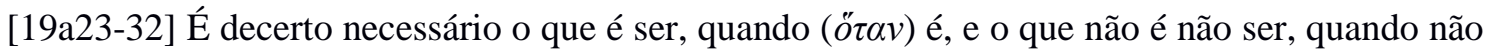
é. No entanto, não é necessário ser tudo o que é, nem não ser tudo o que não é. Pois não é o mesmo tudo o que é ser por necessidade, quando é, e ser por necessidade simplesmente, e assim também no que concerne ao que não é. E o mesmo argumento vale para os contraditórios. É de fato necessário tudo ser ou não ser e, por certo, vir a ser ou não vir a ser; mas não, dividindo, dizer que uma das duas <partes> é necessária. Quero dizer, por exemplo: é necessário que haverá ou não haverá uma batalha naval amanhã; não é, contudo, necessário que aconteça uma batalha naval amanhã, nem que não aconteça. No entanto, necessariamente acontecerá ou não acontecerá. 
$\mathrm{O}$ indeterminismo aristotélico não implica romper incondicionalmente com o axioma de Parmênides: o que é, não é possível que não seja; o que não é, é necessário que não seja. O axioma é, sem dúvida, válido, desde que referido ao que atualmente é e atualmente não é, ou seja, desde que entendido como a postulação da necessidade do presente. Ora, argumenta Aristóteles, a necessidade do presente, modalidade relativa, não equivale à necessidade simples, absoluta, incondicional, precisamente porque há o contingente.

Se algo ocorre em um momento $m$, então é certo que, em $m$, é necessário que ocorra em $m$, o que, porém, não implica que seja simplesmente necessário - e, portanto, que sempre tenha sido necessário - que ocorra em $m$. Se algo não ocorre em $m$, então é certo que, em $m$, é necessário que não ocorra em $m$, o que, porém, não implica que seja simplesmente necessário - e, portanto, que sempre tenha sido necessário - que não ocorra em $m$.

Isso porque há o contingente. Há o que ocorre em $m$ e, por isso, está determinado em $m$ que ocorra em $m$, mas, em algum momento anterior a $m$, ainda não estava inflexivelmente determinado que ocorreria em $m$. E há o que não ocorre em $m \mathrm{e}$, por isso, está determinado em $m$ que não ocorra em $m$, mas, em algum momento anterior a $m$, ainda não estava inflexivelmente determinado que não ocorreria em $m .^{35}$

Pode-se dizer o mesmo a respeito do que enunciados contraditórios afirmam e negam que ocorra em algum momento. Se um enunciado afirma e outro nega que um estado de coisas ocorrerá em $m$, então o princípio do terceiro excluído garante que necessariamente se realizará uma ou outra das duas alternativas, ocorrer em $m$ e não ocorrer em $m$ : necessariamente ou ocorrerá em $m$ ou não ocorrerá em $m$. Ora, pela necessidade do presente, se o estado de coisas ocorrer em $m$, então será necessário em $m$ que ocorra em $m$; se não ocorrer em $m$, então será necessário em $m$ que não ocorra em $m$. Portanto, do princípio do terceiro excluído e da necessidade do presente, pode-se inferir

\footnotetext{
${ }^{35}$ Há quem não encontre, na primeira frase do trecho, o enunciado da tese da necessidade do presente, sob a alegação de que a conjunção ö $\tau \alpha v$ não teria, na frase, valor temporal, mas meramente condicional; cf. Fine 1984, 23-47. De fato, a conjunção pode ser empregada com esse valor semântico, tanto quanto a conjunção "quando" em português. No entanto, o fato inquestionável de que Aristóteles admite modalidades temporais e o modo como essas modalidades podem ser definidas em termos das modalidades condicionais, acima mencionado, tornam a alegação irrelevante, ainda que fosse verdadeira. Se é necessário Y ser o caso sob a condição de $\mathrm{X}$ ser o caso, então, quando $\mathrm{X}$ vem a ser o caso, passa a ser necessário Y ser o caso. Assim, "é necessário o que é ser, se é" implica trivialmente "é necessário o que é ser, quando é."
} 
que ou será necessário em $m$ que o estado de coisas ocorra em $m$ ou será necessário em $m$ que não ocorra em $m$.

No entanto, pela mesma razão pela qual não se pode inferir, da necessidade do presente, que, se o estado de coisas ocorrer (não ocorrer) em $m$, então é simplesmente necessário e sempre foi necessário ocorrer (não ocorrer) em $m$, tampouco se pode inferir, do terceiro excluído e da necessidade do presente, que ou é simplesmente necessário, e sempre foi necessário, ocorrer em $m$ ou é simplesmente necessário, e sempre foi necessário, não ocorrer em $m$.

A razão é que há o contingente. Há o que estará determinado em $m$ que ocorra (não ocorra) em $m$, mas, em algum momento anterior a $m$, ainda não estava inflexivelmente determinado nem que ocorreria em $m$ nem que não ocorreria em $m$ ainda que sempre estivesse inflexivelmente determinado que ou ocorreria em $m$ ou não ocorreria em $m$. Por exemplo, sempre esteve inflexivelmente determinado que uma ou outra das duas alternativas se realizará, haver uma batalha naval amanhã e não haver uma batalha naval amanhã. Qual delas se realizará, porém, é algo que, muito provavelmente, só estará inflexivelmente determinado amanhã, não antes.

\subsection{Segunda Parte}

[19a32-39] Portanto, dado que os enunciados são verdadeiros do mesmo modo como são as coisas, é claro que, no caso de serem elas tais que calhem de acontecer como uma de duas <alternativas>

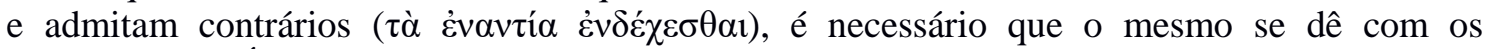
contraditórios. É o que se dá precisamente (ő $\pi \varepsilon \rho ~ \sigma v \mu \beta \alpha i v \varepsilon \imath$ ) com aquelas que nem sempre são ou nem sempre não são. Pois, a respeito delas, é necessário um dos dois contraditórios ser verdadeiro ou falso, mas não este ou aquele, e sim o que calhar de o ser como uma de duas <alternativas>; e, mesmo sendo um mais verdadeiro que o outro, não é, contudo, já [ou: por isso] verdadeiro ou falso.

[19a39-b4] Portanto, é evidente que não é necessário, no caso de toda afirmação e negação opostas, uma delas ser verdadeira e a outra falsa. Pois não é tal como se passa no caso do que é que também se passa no caso do que não é, mas pode ser ou não ser, e sim como foi dito.

Concedida a tese indeterminista, a conclusão do argumento direto obtém-se mediante apelo à dependência causal da verdade ou falsidade de um enunciado com respeito a ocorrer ou não ocorrer o que o enunciado diz ocorrer. Em um momento $m$, um enunciado está para a verdade e a falsidade assim como a realidade do que ele diz ocorrer em um momento $m$ ' está para o modo como as coisas realmente são e vieram a ser em $m$. Se o modo como as coisas realmente são e vieram a ser em $m$ é causa suficiente da realidade do que um enunciado diz ocorrer em $m$ ', então em $m$ está determinada a verdade 
do enunciado, e o enunciado é verdadeiro em $m$. Se o modo como as coisas realmente são e vieram a ser em $m$ é causa suficiente da irrealidade do que um enunciado diz ocorrer em $m$ ', então em $m$ está determinada a falsidade do enunciado, e o enunciado é falso em $m$.

No que concerne ao presente e ao passado, essas são as duas únicas possibilidades. No entanto, no que concerne ao futuro, há o contingente. Se o modo como as coisas realmente são e vieram a ser em $m$ não determina inflexivelmente que realmente ocorrerá nem tampouco que realmente não ocorrerá o que um enunciado diz que ocorrerá em um momento posterior $m$ ', então em $m$ ainda não está inflexivelmente determinada nem a verdade nem a falsidade do enunciado, pois a indeterminação no plano das causas implica a indeterminação no plano dos efeitos, a indeterminação no plano das coisas implica a indeterminação no plano da verdade e falsidade. Nesse caso, em $m$ não é necessário que o enunciado seja verdadeiro e não é necessário que seja falso. Portanto, pela necessidade do presente, em $m$ o enunciado não é nem verdadeiro nem falso.

A letra do trecho parece não dar margem a dúvidas. Dado que, em $m$, o estado de coisas que o enunciado diz que ocorrerá em $m$ ' pode ocorrer em $m$ ' e também pode não ocorrer em $m$ ', Aristóteles conclui que também o enunciado "admite contrários" - e não se vê como entender essa conclusão senão como a afirmação de que, em $m$, o enunciado pode ser verdadeiro e pode também ser falso, não sendo, por conseguinte, dada a necessidade do presente, nem atualmente verdadeiro nem atualmente falso.

Assim, dado um par qualquer de contraditórios, um dos quais afirma e o outro nega que algo ocorrerá no futuro, o princípio do terceiro excluído e a definição de verdade garantem que, no futuro, um dos dois será verdadeiro e o outro será falso. No entanto, isso não é o mesmo que dizer que um deles em particular será o verdadeiro e o outro será o falso, de modo que não se pode, em todos os casos, inferir que um deles em particular seja hoje verdadeiro e o outro seja hoje falso. Se o que é afirmado e negado é um futuro contingente, nenhum dos contraditórios é agora verdadeiro e nenhum deles é agora falso. Se um deles afirmar a ocorrência futura de um estado de coisas ou conexão predicativa que ocorre no mais das vezes, mas nem sempre, agora é decerto mais provável que, no futuro, venha a ser ele o verdadeiro, mas nem por isso ele é agora atualmente verdadeiro.

O trecho final do capítulo (19a39-b4) expressamente ratifica a tese que o trecho inicial (18a28-33) propusera e os argumentos expostos no capítulo estabelecem. Para os enunciados sobre o futuro, não vale universalmente algo que vale universalmente para os enunciados sobre o presente e o passado: a lei de distribuição. Portanto, para os 
enunciados sobre o futuro, tampouco vale universalmente a lei de bivalência, que vale universalmente para os enunciados sobre o presente e o passado. Tradicionalmente interpretado, o capítulo entrega, como conclusão dos argumentos que expõe, precisamente aquilo que de início prometera entregar.

\section{A Bivalência Atenuada}

Em 19a36-37, Aristóteles afirma que, no caso dos enunciados sobre futuros contingentes, "é necessário um dos dois contraditórios ser verdadeiro ou falso". O trecho é ambíguo, pois é ambígua, em português como em grego, a combinação de um predicado modal com uma sentença infinitiva. A sentença "É necessário Édipo ser o rei de Tebas", por exemplo, pode ser entendida como a afirmação de que é agora necessário que Édipo seja agora o rei de Tebas, mas também como a afirmação de que é agora necessário que Édipo venha a ser o rei de Tebas no futuro. Do mesmo modo, o trecho em questão pode ser entendido como a afirmação de que é agora necessário um ou outro dos contraditórios ser agora verdadeiro ou falso e, de modo geral, como a afirmação de que, em um momento $m$ qualquer, é necessário em $m$ um ou outro dos contraditórios ser em $m$ verdadeiro ou falso. Pode, contudo, ser também entendido como a afirmação de que é agora necessário um ou outro dos contraditórios ser verdadeiro ou falso no futuro e, de modo geral, como a afirmação de que, em um momento $m$ qualquer, é necessário em $m$ um ou outro dos contraditórios ser verdadeiro ou falso em algum momento posterior a $m$.

Conforme o primeiro entendimento, o trecho afirma que a lei de bivalência vale universalmente também para os enunciados sobre o futuro, de modo que vale para todo e qualquer enunciado. Conforme o segundo entendimento, afirma que vale universalmente para os enunciados sobre futuros contingentes uma versão modificada da lei de bivalência: cada um desses enunciados necessariamente será verdadeiro ou falso. Assim, conforme esse entendimento, ele afirma que vale universalmente uma versão atenuada da lei de bivalência: todo enunciado necessariamente é ou será verdadeiro ou falso.

Sendo essas as duas únicas maneiras de se entender o trecho, a adesão à interpretação tradicional do capítulo obriga a que nele se encontre essa versão atenuada da lei de bivalência. Ora, estabelecer a compatibilidade entre a universalidade da bivalência atenuada e o sistema das teses expostas no capítulo não é tarefa trivial. Cumprila requer, em primeiro lugar, que sejam apropriadamente regulamentadas a vagueza e as ambiguidades que caracterizam o uso ordinário de verbos como "dizer", "enunciar", 
"afirmar", "negar", assim como os substantivos correspondentes, "enunciado", "afirmação", "negação" - vagueza e ambiguidade que Aristóteles acolhe ao fazer uso técnico desses termos na formulação de sua teoria do discurso enunciativo. E requer, em segundo lugar, que se mostre ser plausível que Aristóteles esteja comprometido com uma versão atenuada do princípio de plenitude.

\subsection{Enunciados Temporalmente Absolutos e Relativos}

Em De Interpretatione 4-6, Aristóteles introduz o conceito de discurso

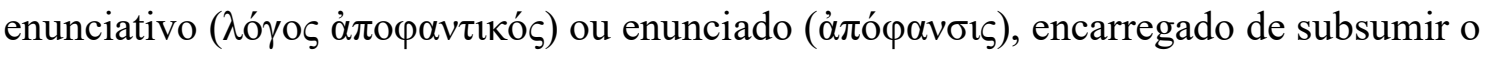
que entende serem, no domínio da linguagem, os alvos primários de atribuições de verdade e falsidade. Discursos são suscetíveis de verdade e falsidade na exata medida em que enunciam que ocorre algo que, ao menos em princípio, pode ocorrer e pode não ocorrer. Os casos mais simples de enunciados são as afirmações e negações, que respectivamente afirmam e negam que um predicado pertença a um sujeito, por vezes com referência a um tempo determinado.

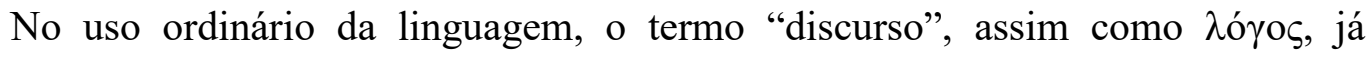
comporta uma ambiguidade. Pode-se entender que um discurso é a sequência de símbolos significativos que são emitidos quando se discorre. E pode-se também entender que um discurso é a emissão de uma tal sequência, a própria ação de emiti-la - ação que, por sua vez, pode ser entendida seja como algo singular e irrepetível, seja como um tipo abstrato de que ações singulares seriam exemplares, de modo que uma mesma ação pode ser praticada por duas pessoas, ou por uma pessoa em momentos diferentes.

Em De Interpretatione 4, ao definir o sentido técnico que empresta a $\lambda$ ó $\gamma$ os, Aristóteles preserva a ambiguidade. Tomando a linguagem falada como o paradigma originário da linguagem em geral, tal como postulado em De Interpretatione 1, define discurso como sendo uma espécie de $\varphi \omega v \eta ́$ significativa. Ora, a palavra $\varphi \omega v \eta ́$ pode designar um som vocal, o que se profere quando se fala, mas também pode designar a proferição de um som vocal, a própria ação de proferi-lo.

Evidentemente, essa ambiguidade contamina a definição do conceito de discurso enunciativo ou enunciado. Essa definição permite que se entenda que um discurso enunciativo é um símbolo semanticamente complexo apto a veicular a asserção de que algo ocorre - símbolo que, apenas para dispor de um rótulo, chamarei de sentença. E também permite que se entenda que um discurso enunciativo é a emissão de uma 
sentença, a própria ação de emiti-la - que, por sua vez, pode ser entendida seja como uma ação singular irrepetível, seja como um tipo abstrato de que ações singulares seriam exemplares.

Embora Aristóteles nunca tenha resolvido expressamente a ambiguidade, o modo como frequentemente emprega os termos "verdadeiro" e "falso" favorece o entendimento de que um enunciado é a ação de emitir assertivamente uma sentença. Nos textos da Metafísica em que apresenta definições de verdade e falsidade, e em muitos outros textos, inclusive em De Interpretatione 9, Aristóteles formula atribuições de verdade e falsidade por meio de expressões da forma "é verdadeiro (falso) dizer que $S$ ", sendo $S$ uma sentença, de preferência a expressões da forma "é verdadeiro (falso) que $S$ ". Isso sugere que, no domínio da linguagem, os alvos primários dessas atribuições, os enunciados, sejam propriamente não sentenças, mas atos de dizer, emissões de sentenças.

A questão de saber se o que merece ser mais propriamente dito verdadeiro e falso são sentenças ou emissões de sentenças pode parecer bizantina, e realmente seria bizantina, se tudo o que um enunciado enuncia já estivesse incluído na significação da sentença cuja emissão o veicula, de modo que todas as emissões de uma mesma sentença enunciassem sempre a mesma coisa. No entanto, há um sentido de "enunciar" e "enunciado", assim como de "afirmar", "negar", "afirmação" e "negação", em que uma certa espécie de sentenças não satisfaz essa condição. São as sentenças que podemos chamar de temporalmente relativas.

Por simplicidade, consideremos apenas sentenças que não contenham elementos dêiticos não temporais. São temporalmente relativas sentenças que contêm dêiticos temporais, como terminações verbais e expressões da espécie de "agora", "durante todo o dia de ontem", "amanhã". Um dêitico temporal pode fazer referência a diferentes tempos nos diferentes momentos em que seja emitido, tempos delimitados sempre por meio de uma mesma relação, semanticamente associada ao dêitico, que mantenham com o momento da emissão. Nessa medida, diferentes emissões de uma sentença desse tipo, sem alteração dos sentidos de suas partes, podem ter diferentes condições de verdade, já que enunciam (afirmam, negam) que algo é o caso em tempos diferentes.

Sentenças temporalmente relativas, como "Sócrates está sentado" e "Sócrates estará no mercado amanhã", contrastam com as temporalmente absolutas, como "Sócrates morre antes da morte de Platão". Estas enunciam (afirmam, negam) que algo ocorre (Sócrates morrer, nesse exemplo) em um tempo determinado (na porção do tempo 
aberta na direção do passado que termina no momento da morte de Platão, nesse exemplo), sempre o mesmo em todas as suas emissões.

Tal como ordinariamente utilizados os verbos "enunciar", "dizer", "afirmar" e "negar", a questão de saber o que enuncia (diz, afirma, nega) a emissão de uma sentença temporalmente relativa em um dado momento admite respostas incompatíveis, pois o que uma tal emissão enuncia pode ser individuado segundo critérios incompatíveis. Consideremos os casos que Aristóteles afirma serem os mais simples, as afirmações e as negações predicativas.

O que uma emissão da sentença "Sócrates estará no mercado amanhã" em um dado momento enuncia (diz, afirma) pode ser individuado de dois modos. Por um lado, pode ser individuado: (a) pelo fato de veicular uma afirmação, ao invés de uma negação; (b) por fazer referência precisamente ao sujeito e ao predicado a que faz referência; (c) por delimitar o tempo em que o predicado deve pertencer ao sujeito para que o enunciado seja verdadeiro precisamente da maneira como o delimita, ou seja, mediante precisamente aquela relação com o momento da emissão do enunciado que está semanticamente associada ao dêitico temporal "amanhã", não importa qual seja esse momento. É na acepção definida por esse modo de individuação, que podemos chamar de temporalmente relativa, que se diz que quem emite hoje essa sentença enuncia, diz ou afirma a mesma coisa que enunciou, disse ou afirmou quem a emitiu ontem, a saber, que um mesmo predicado pertence a um mesmo sujeito no dia seguinte ao da emissão do enunciado, não importa qual seja esse dia.

Por outro lado, o que uma emissão dessa mesma sentença nesse mesmo momento enuncia (diz, afirma) pode também ser individuado: (a) pelo fato de veicular uma afirmação; (b) por fazer referência precisamente ao sujeito e ao predicado a que faz referência; (c) pela porção determinada do tempo (intrinsecamente definida por suas relações com as demais porções do contínuo temporal) que, por meio do dêitico e do momento da emissão do enunciado, se estabelece ser aquela em que o predicado deve pertencer ao sujeito para que o enunciado seja verdadeiro. É na acepção definida por esse segundo modo de individuação, que podemos chamar de temporalmente absoluta, que se diz que quem emite essa sentença hoje e quem a emitiu ontem enunciam (dizem, afirmam) coisas diferentes, já que afirmam que o mesmo predicado pertence ao mesmo sujeito, mas em porções diferentes do tempo. E nessa acepção, quem emite hoje a sentença enuncia a mesma coisa que enunciará (dirá, afirmará) quem emitir, depois de amanhã, a sentença "Sócrates esteve no mercado ontem". 
Consideremos um enunciado como um tipo abstrato, cujos exemplares são ações singulares de emitir uma sentença, também considerada como um tipo abstrato. $\mathrm{O}$ uso ordinário da linguagem, no caso do português e do grego, admite que se tome, mas também que não se tome, a sentença cuja emissão veicula um enunciado como relevante para a individuação desse enunciado. Um enunciado, porém, é sempre individuado, se não apenas, ao menos também por aquilo que enuncia, de modo que emissões que enunciam coisas diferentes são, por princípio, enunciados diferentes.

Portanto, na medida em que duas emissões de uma mesma sentença temporalmente relativa, sem alteração dos sentidos de suas partes, sempre enunciam, na acepção temporalmente relativa, a mesma coisa, elas são, nessa acepção, dois exemplares do mesmo enunciado. No entanto, na medida em que duas emissões de uma tal sentença podem enunciar, na acepção temporalmente absoluta, coisas diferentes, elas podem ser, nessa acepção, exemplares de enunciados diferentes. Todo exemplar de um enunciado temporalmente relativo é também um exemplar de um enunciado temporalmente absoluto, mas dois exemplares de um mesmo enunciado temporalmente relativo podem ser exemplares de dois enunciados temporalmente absolutos.

O princípio de não contradição garante que dois exemplares de um mesmo enunciado temporalmente absoluto nunca tenham diferentes valores de verdade, já que afirmam ou negam que o mesmo estado de coisas ocorre no mesmo momento ou na mesma porção determinada do tempo. Por outro lado, precisamente porque dois exemplares de um mesmo enunciado temporalmente relativo podem ser exemplares de dois enunciados temporalmente absolutos, elas podem ter diferentes condições de verdade e, portanto, diferentes valores de verdade.

Assim, é o conceito temporalmente relativo de enunciado que intervém em Categorias 5, onde Aristóteles argumenta que a tese de que apenas substâncias admitem contrários não é prejudicada pelo fato de que um mesmo discurso - por exemplo, o enunciado de que alguém está sentado - pode ser verdadeiro em um momento e passar a ser falso em outro: verdadeiro enquanto está sentado, falso quando se levantar. ${ }^{36}$

Em De Interpretatione 9, porém, e de modo mais claro na exposição do argumento

\footnotetext{
${ }^{36}$ Cf. Categorias 5, 4a23-b13; cf. também Metafísica IX 10, 1051b14-17: "a respeito dos contingentes ( $\dot{\varepsilon} \delta \varepsilon \chi \chi 0 ́ \mu \varepsilon v \alpha)$, portanto, a mesma opinião e o mesmo discurso vêm a ser verdadeiros e falsos, e podem ser ora verdadeiros, ora falsos. A respeito do que é impossível ser de outro modo, porém, os mesmos não vêm a ser ora verdadeiros, ora falsos, mas são sempre verdadeiros ou sempre falsos."
} 
determinista, prevalece o conceito temporalmente absoluto de enunciado, indispensável para a formulação da tese da retroatividade da verdade. No trecho em que essa tese é introduzida (18b1-2), os verbos “afirmar" e "negar" só podem ser entendidos na acepção temporalmente absoluta: "se é branco ou não branco, então era verdadeiro ou afirmá-lo ou negá-lo". Se isso é branco hoje, o que a lei universal de bivalência implica que já era verdadeiro afirmar, por exemplo, ontem? Certamente não o que a afirmação "isso é branco" sempre afirma, na acepção temporalmente relativa, pois afirmá-lo ontem, nessa acepção, equivaleria a afirmar o que "isso era branco ontem”, nessa acepção, afirma hoje. O que a lei implica é que ontem já era verdadeiro afirmar, na acepção temporalmente absoluta (mediante a emissão, por exemplo, de "isso será branco amanhã"), o que a afirmação "isso é branco" afirma hoje, nessa acepção.

Logo em seguida (18b9-10), a tese da retroatividade é formulada de modo tal a admitir que o verbo "dizer" seja entendido na acepção temporalmente relativa: "se isso agora é branco, antes era verdadeiro dizer "será branco"”. No entanto, sem recorrer ao conceito de enunciado temporalmente absoluto, não há como justificar, suposta a validade universal da lei de bivalência, que, se isso agora é branco, então ontem, por exemplo, era verdadeiro dizer "isso será branco amanhã". Se isso agora é branco, ontem era verdadeiro dizer “isso será branco amanhã” precisamente porque ter emitido essa sentença ontem é ter enunciado, na acepção temporalmente absoluta, que isso agora é branco. De modo geral, não há como, sem recorrer ao conceito de enunciado temporalmente absoluto, formular e derivar da lei universal de bivalência a tese da retroatividade: na hipótese de todo enunciado ser verdadeiro ou falso, se um estado de coisas ocorre em um momento $m$, então, pelo princípio de não contradição, sempre foi verdadeiro, antes de $m$, qualquer enunciado que enuncie, na acepção temporalmente absoluta, que esse estado de coisas ocorre em $m$.

O conceito de enunciado temporalmente absoluto é também requerido para a formulação aceitável, do ponto de vista indeterminista, da versão atenuada da lei universal de bivalência. Desse ponto de vista, por exemplo, é ao menos possível, se não plausível, que, enquanto houver seres humanos, a ocorrência ou não ocorrência de uma batalha naval, efeito de atos de escolha e acontecimentos casuais, nunca esteja absolutamente determinada a acontecer ou não acontecer um ano antes de acontecer ou não acontecer. Na medida em que é ao menos possível que, tal como Aristóteles acredita, a espécie humana vá existir durante todo o tempo infinito, isso implica que em nenhum momento será verdadeira nem será falsa nenhuma emissão do enunciado temporalmente relativo 
veiculado pela sentença "haverá uma batalha naval dentro de um ano", dado que em nenhum momento estará absolutamente determinada a ocorrência ou não ocorrência de uma batalha naval dentro de um ano.

Já o enunciado temporalmente absoluto veiculado por uma emissão dessa sentença em um dado momento $m$ será necessariamente verdadeira ou falsa em algum momento posterior a $m$, a saber, no momento preciso em que a predição completar um ano. Assim, na formulação da lei de distribuição atenuada em 19a36-37, deve-se entender que o termo "contraditórios" denota enunciados temporalmente absolutos.

\subsection{Bivalência e Plenitude}

No entanto, se é certo que a versão atenuada da lei de bivalência, do ponto de vista indeterminista, não vale universalmente para enunciados temporalmente relativos, à primeira vista não é evidente que, desse ponto de vista, valha universalmente sequer para os temporalmente absolutos.

Todo enunciado temporalmente absoluto que diga que um estado de coisas ocorrerá em um determinado momento futuro ou em uma parte de uma porção fechada do futuro será verdadeiro ou falso no futuro, a saber, nesse determinado momento ou, no mais tardar, no momento final dessa porção fechada. É o caso, por exemplo, do enunciado temporalmente absoluto veiculado por uma emissão de "haverá uma batalha naval amanhã": ele necessariamente será verdadeiro ou falso à meia-noite de amanhã.

Será também verdadeiro ou falso todo enunciado temporalmente absoluto que diga que um estado de coisas contingente ocorrerá em alguma parte indeterminada de uma porção aberta do tempo na direção do futuro, se, em algum momento do futuro, esse estado de coisas ocorrer ou se tornar impossível que ocorra posteriormente: o enunciado

será verdadeiro ou falso nesse exato momento. É o caso, por exemplo, de uma emissão de "Este manto será cortado no futuro". Dado que o manto necessaria e irreversivelmente se corromperá, ou ele terá sido cortado em algum momento anterior à sua corrupção e, a partir desse momento, o enunciado será verdadeiro, ou não terá sido cortado até o momento de sua corrupção e, a partir desse momento, será impossível que seja cortado, de modo que, a partir de então, o enunciado será falso.

Considere-se, porém, uma sentença que, emitida agora, afirme ou negue, na acepção temporalmente absoluta, que um estado de coisas ocorrerá em alguma parte indeterminada de uma porção do tempo aberta na direção do futuro. Suponha-se que, em 
todo momento do futuro, seja contingente que ele venha a ocorrer posteriormente. Nesse caso, é evidente que, se o estado de coisas nunca ocorrer, em cada momento do futuro o enunciado não será nem verdadeiro nem falso, pois em nenhum momento do futuro o estado de coisas ocorrerá nem estará determinado que não ocorrerá posteriormente. Assim, admitindo-se, como acima, que em nenhum momento está determinado que uma batalha naval nunca mais aconteça e supondo-se que, após um dado momento, nunca mais aconteça nenhuma batalha naval, o enunciado temporalmente absoluto veiculado por uma emissão, nesse dado momento, de "haverá uma batalha naval" nunca será, após esse momento, nem verdadeiro nem falso. À primeira vista, a bivalência atenuada tampouco vale necessária e universalmente para os enunciados temporalmente absolutos.

A solução para essa dificuldade parece estar bem à mão: no próprio capítulo, na sentença imediatamente anterior à formulação da bivalência atenuada. Após afirmar que a bivalência forte não vale para enunciados sobre futuros contingentes, Aristóteles diz:

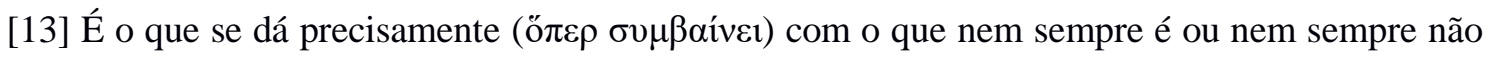
é. (19a35-36)

No contexto, [13] certamente afirma que, se um estado de coisas ocorre em algum momento, mas nem sempre ocorre, ou se não ocorre em algum momento, mas nem sempre não ocorre, então ele é contingente. Entretanto, a expressão "é o que se dá precisamente" sugere que [13] afirma também a condicional inversa, de modo que, tomada literalmente, [13] afirmaria:

[14] Os estados de coisas contingentes são precisamente (ou seja, nada mais e nada menos que) os que ocorrem em algum momento e não ocorrem em outro momento.

Levando-se em conta que as modalidades relevantes para a discussão em curso são modalidades temporais, [13] deveria ser entendida como:

[15] Os estados de coisas contingentes em um momento $m$ são precisamente (ou seja, nada mais e nada menos que) os estados de coisas que, se ocorrem em $m$, então não ocorrem em algum momento posterior a $m$ e, se não ocorrem em $m$, então ocorrem em algum momento posterior a $m$.

Ora, é evidente que a adoção de [15] bastaria para caucionar a validade universal da lei de bivalência atenuada no domínio dos enunciados temporalmente absolutos. Essa lei apenas poderia ser transgredida por enunciados que asseverassem a ocorrência de estados de coisas sempre contingentes que, a partir de um dado momento, nunca mais 
ocorressem - estados de coisas cuja existência é excluída por [15]. Infelizmente, acontece ser também evidente que o princípio de caridade proíbe terminantemente que se encontre em [13] a afirmação de [15]. Isso porque [15] equivale trivialmente ao princípio de plenitude forte, que Aristóteles acabara de rejeitar em 19a12-16, poucas linhas antes de enunciar [13].

No entanto, duas considerações podem indicar o caminho para uma interpretação caridosa de [13] apta a garantir a validade universal da lei de bivalência atenuada e, ao mesmo tempo, solucionar a dificuldade de conciliá-la, no contexto de De Interpretatione 9, com a recusa explícita do princípio de plenitude forte.

\subsubsection{A Plenitude Atenuada}

Em primeiro lugar, é relevante observar que a dificuldade afeta não apenas a coerência interna do capítulo, mas também a compatibilidade entre ele e outros textos de Aristóteles, que parecem enunciar [14] e outras teses equivalentes a [14]: se algo pode não ser, em algum momento não é; se algo é sempre, necessariamente é:

\section{(...) pois o que pode não ser não é eterno. (Metafísica XIV 2, 1088b23-24)}

Portanto, se é por necessidade, é eterno e, se eterno, por necessidade. E, por conseguinte, se o vir a ser de algo é necessário, seu vir a ser é eterno e, se eterno, necessário. (De Generatione et Corruptione, II 11, 338a1-3)

Nesses trechos (assim como em Metafísica IX 8, onde a distinção entre o eterno e o perecível, o que pode perecer, é tratada como exaustiva e exclusiva) ${ }^{37}$, Aristóteles limita-se a enunciar as teses, sem argumentar em seu favor. O único texto conhecido em que formula um argumento em favor de uma delas é De Caelo I 12. A validade do argumento é controversa. No entanto, é inquestionável que Aristóteles o considera válido e toma suas premissas como verdadeiras, no que concerne não apenas à existência, mas, de modo geral, ao ser das coisas "em qualquer das categorias; por exemplo, ser homem, ser branco, (...) ou o que quer que seja". ${ }^{38}$ Assim, é inquestionável que o texto pretende fundamentar, entre outras teses, a equivalência entre ser eterno e ser necessário, tanto na acepção absoluta e existencial, como na acepção predicativa de "ser": se algo existe, ou

\footnotetext{
${ }^{37}$ Cf. Metafísica IX 8, 1050b6-28

${ }^{38}$ De Caelo I 12, 281a31-33.
} 
tem um predicado, desde sempre e para sempre, então é simplesmente necessário que exista, ou tenha esse predicado, desde sempre e para sempre.

Assim, esses textos tornam plausível a hipótese de que Aristóteles adote ao menos alguma versão restrita ou atenuada do princípio de plenitude, compatível com uma interpretação caridosa desses textos. Adotar o princípio de plenitude equivale a adotar uma concepção das modalidades aléticas comumente qualificada como estatística: uma concepção que, mesmo não definindo essas modalidades em termos frequenciais, admite que condições necessárias e suficientes de qualificações modais de estados de coisas e conexões predicativas se formulem em termos de graus de frequência com que esses estados de coisas e conexões predicativas ocorrem. Portanto, esses textos tornam plausível a hipótese de que Aristóteles adote ao menos alguma espécie restrita ou atenuada de concepção estatística das modalidades aléticas.

Essa hipótese é reforçada pelo modo como Aristóteles distingue os graus de contingência de estados de coisas e conexões predicativas: a probabilidade e a indeterminação completa. Ao caracterizá-los como graus de contingência, Aristóteles faz dessas modalidades termos intermediários em uma escala cujos limites superior e inferior são, respectivamente, a necessidade e a impossibilidade. A distinção entre essas modalidades é decerto fundamentada em termos dos diferentes graus de tendência causal a ocorrer e não ocorrer de que estados de coisas e conexões predicativas são suscetíveis, em função das capacidades das coisas neles envolvidas. No entanto, a distinção entre o necessário, o provável e o acidental, por exemplo, é elucidada em inúmeros textos aristotélicos também em termos frequenciais, como se fosse equivalente à distinção entre o que ocorre sempre, o que ocorre (e não apenas pode ocorrer) no mais das vezes, mas nem sempre, e o que ocorre (e não apenas pode ocorrer) raramente. Se lemos literalmente esses textos (o que somos tentados, mas não obrigados, a fazer), neles encontramos a concepção estatística forte das modalidades aléticas. Ainda que lidos caridosamente, parece inevitável neles encontrar ao menos alguma versão restrita ou atenuada dessa concepção. ${ }^{39}$

\footnotetext{
${ }^{39} \mathrm{Um}$ texto exemplar a esse respeito é Metafísica VI 2, 1027b27-34: "ora, dado que, entre as coisas que são, algumas estão no mesmo estado sempre e por necessidade (não como o que se diz ser por coerção, mas como o que se diz não poder ser de outro modo) e algumas são não por necessidade e sempre, mas no mais das vezes, esse é o princípio e essa é a causa de haver o acidental; pois o que não é sempre nem no mais das vezes é o que afirmamos ser acidental." Como o faz em Primeiros Analíticos I 13, 32b4-13, texto que se propõe expressamente a distinguir dois tipos de contingência, Aristóteles emprega preferencialmente, para denotar o contingente brando,
} 
Os efeitos aparentemente deletérios da primeira consideração podem ser contrabalançados pela segunda: o princípio de plenitude forte é mais do que Aristóteles precisa para estabelecer a validade universal da bivalência atenuada. Para tanto, requerse tão somente que seja excluída a existência de estados de coisas e conexões predicativas sempre possíveis e nunca reais. Para tanto, podemos nos contentar com uma versão atenuada do princípio:

[16] Todo estado de coisas ou conexão predicativa que seja possível em um momento $\mathrm{m} \mathrm{e} \mathrm{em}$ todo momento posterior a $m$ ocorre em algum momento posterior a $m$.

O princípio de plenitude forte afirma que todo estado de coisas ou conexão predicativa que, em um dado momento, seja possível, mas não ocorra, acabará por ocorrer posteriormente. O princípio atenuado afirma que, durante uma porção aberta do tempo na direção do futuro, nenhum estado de coisas ou conexão predicativa permanece sempre possível sem nunca ocorrer. O princípio atenuado convive harmoniosamente com 19a1216. O manto de Aristóteles desgastou-se antes de ser cortado. A partir do momento em que se desgastou e deixou de existir, passou a ser impossível o estado de coisas, antes possível, que consiste em ser cortado o manto, pois, a partir desse momento, já nada mais havia para ser cortado. Esse estado de coisas foi possível, mas não para sempre, de modo que a ele não se aplica o princípio de plenitude atenuado. E é evidente que a atribuição dessa versão do princípio a Aristóteles solucionaria a dificuldade de se estabelecer a validade universal da bivalência atenuada no contexto de De Interpretatione 9, tradicionalmente interpretado.

Na verdade, essa atribuição não é apenas uma solução possível para a dificuldade, mas é a única solução. Isso porque nenhuma tese mais fraca que [16] seria capaz de solucioná-la, na medida em que a bivalência atenuada é não apenas implicada pela plenitude atenuada, mas evidentemente também a implica. Portanto, o intérprete tradicional do capítulo está inapelavelmente destinado a fazer essa atribuição.

Felizmente, esse não é um destino ingrato. Pelo contrário. Dado que vários textos indicam a disposição de Aristóteles a associar, de alguma maneira, critérios frequenciais a modalidades aléticas, a associação de critérios que impliquem [16], mas não o princípio de plenitude forte, é, do ponto de vista exegético, tudo menos arbitrária.

a expressão frequencial "o que é no mais das vezes". 
O que [16] faz é limitar a esfera de aplicação do princípio de plenitude ao domínio dos estados de coisas e conexões predicativas que permanecem possíveis durante uma porção aberta do tempo na direção do futuro, excluindo dessa esfera os estados de coisas e conexões predicativas possíveis até certo momento e depois impossíveis. Ora, no contexto científico de Aristóteles, essa limitação parece ser bastante razoável. Com efeito, ela pode ser vista como o resultado do refinamento teórico do modo como a associação entre graus de frequência e modalidades aléticas opera como um componente de nosso bom senso explanatório - entendido como o conjunto de conceitos e máximas que, na vida cotidiana, nós (inclusive Aristóteles e seus contemporâneos) utilizamos para explicar por que as coisas são como são e acontecem como acontecem, assim como para prever como as coisas serão e acontecerão.

Muitos dos conceitos centrais da filosofia aristotélica resultam do refinamento teórico de componentes de nosso bom senso explanatório. Um dos exemplos mais flagrantes é o conceito de causa, cuja conformação foi claramente inspirada pelas espécies de respostas que ordinariamente nos satisfazem quando perguntamos por que algo é como é ou acontece como acontece. Para explicar por que a cadeira em que estou sentado é incômoda, é apropriado dizer que é dura (explicação pela matéria) ou que é estreita (explicação pela forma). Para explicar por que escrevo este artigo, é apropriado dizer que fui estimulado a fazê-lo por colegas (explicação pelo motor) ou que o faço para tornar conhecida minha interpretação do argumento da batalha naval (explicação pelo fim).

A associação entre graus de frequência e modalidades aléticas é um dos eixos de nosso bom senso explanatório. Ordinariamente, explicar por que um estado de coisas ocorreu e prever por que ocorrerá consiste em derivar sua ocorrência do que se reputa serem conexões causais - seja entre estados de coisas, seja entre predicados - estritamente necessárias ou, ao menos, prováveis. Ora, no âmbito de nosso bom senso explanatório, o indício básico da regularidade causal, necessária ou probabilística, é o grau de frequência com que, absolutamente ou em condições determinadas, estados de coisas e conexões predicativas ocorrem. Direta ou indiretamente, é com base na estimativa de graus de frequência que ordinariamente conjecturamos que algo ocorreu ou ocorrerá como caso particular de uma regularidade estritamente necessária, como caso particular de uma regularidade apenas probabilística ou de maneira simplesmente irregular.

De modo impreciso, pode-se afirmar que, se um estado de coisas ou conexão predicativa que, em condições favoráveis, ou seja, nas oportunidades que tem para ocorrer, sempre ocorre, tendemos a tomá-lo como necessário; se ocorre no mais das vezes, como 
provável; se ocorre raramente, como completamente indeterminado, na acepção aristotélica. Ora, a afirmação é imprecisa precisamente porque escamoteia o fato crucial de que, no contexto de nosso bom senso explanatório, os significados das expressões "sempre", "no mais das vezes" e "raramente" devem ser entendidos como relativos a conjuntos de oportunidades e a porções do tempo - e relativos não a quaisquer conjuntos de oportunidades nem a quaisquer porções de tempo, mas a conjuntos suficientemente amplos de oportunidades e a porções de tempo suficientemente extensas.

Se observamos que duas ou três pessoas se curaram de uma febre após a ingestão do hidromel, não é razoável inferir daí a existência de uma relação causal, estrita ou tendencial, entre a ingestão do hidromel e a cura da febre. Poderia ter sido uma coincidência. No entanto, se observamos que dezenas de pessoas se curaram da febre após a ingestão do hidromel, nosso bom senso explanatório recomenda que consideremos ao menos como provável que a ingestão do hidromel tenha curado, ou contribuído causalmente para curar, a febre.

Do mesmo modo, se alguns poucos lançamentos sucessivos de um astrágalo resultaram em um Quio ${ }^{40}$, não é razoável inferir daí que os resultados dos lançamentos não tenham sido casuais. No entanto, se milhares de lançamentos resultarem sempre em um Quio, nosso bom senso explanatório recomendará que consideremos esse resultado como causalmente determinado, seja pelos atributos das coisas envolvidas, seja, quem sabe, por uma ação comunicativa dos deuses em benefício de algum oráculo. Isso porque (como observa Aristóteles, em consonância com nosso bom senso explanatório), na suposição de que o resultado seja casual, obter um Quio é relativamente fácil, mas obter milhares seria impraticável ( $\dot{\alpha} \mu \eta \dot{\chi} \chi \alpha \nu o v)^{41}$. Seria muita coincidência.

Agora, passemos ao limite. Suponhamos que um astrágalo, nunca antes lançado, após dois ou três lançamentos sucessivos resultarem casualmente em Quios, tenha sido acidentalmente destruído. É evidente que a destruição acidental do astrágalo em um momento $m$ não pode alterar o estatuto modal das ocorrências anteriores do estado de coisas que consiste em resultar em um Quio um lançamento desse astrágalo. E é também evidente que, após $m$, será sempre impossível que ocorra o estado de coisas, antes contingente, que consiste em ser lançado o astrágalo e esse lançamento resultar não em

\footnotetext{
${ }^{40}$ Sobre os nomes dos lados de um astrágalo, originalmente atribuídos no contexto de jogos de azar e preditivos, cf. História dos Animais II 2, 499b27-30.

${ }^{41}$ Cf. De Caelo II 12, 292a29-30. O contexto desse trecho não faria sentido se não se encontrasse nele a suposição implícita de que o resultado de um lançamento do astrágalo em questão é casual.
} 
Quios, mas em Cós, já que a destruição do osso em $m$ determina que o estado de coisas nunca mais terá oportunidade para ocorrer.

Em suma, a máxima de bom senso explanatório que associa graus de frequência a modalidades não exclui que haja estados de coisas e conexões predicativas que, possíveis em um dado momento, não ocorrem nesse momento nem nunca ocorrerão após esse momento. O exemplo de nosso astrágalo mostra que ela não exclui sequer que haja estados de coisas e conexões predicativas que, possíveis até agora, jamais ocorreram e jamais ocorrerão.

Portanto, não é a concepção estatística forte das modalidades aléticas, equivalente ao princípio de plenitude forte, a que resulta naturalmente do refinamento do modo como a associação entre graus de frequência e modalidades opera no contexto de nosso bom senso explanatório. Ao simplesmente identificar o necessário, o impossível e o contingente ao que ocorre sempre, ao que nunca ocorre e ao que às vezes ocorre e às vezes não, a concepção forte não responde ao fato de que, nesse contexto, a relevância modal dos graus de frequência é relativa a conjuntos de oportunidades suficientemente amplos e porções de tempo suficientemente extensas.

Por um lado, uma concepção estatística que responda a esse fato não exclui a existência de estados de coisas e conexões predicativas que, possíveis em um dado momento, passam a ser impossíveis antes de terem um número de oportunidades de ocorrer suficiente para revelar estatisticamente seu estatuto modal. É o caso do estado de coisas que consiste em ser cortado o manto de Aristóteles, manto que pode ser cortado antes de se desgastar, mas não terá oportunidades nem tempo suficientes para ser cortado antes de se desgastar.

É o caso, para Aristóteles, de todo estado de coisas que, contingente em um momento $m$, consiste em um determinado indivíduo perecível existente em $m$ possuir um determinado predicado. Após o perecimento necessário e irreversível desse indivíduo, o estado de coisas se tornará impossível. E é também o caso, para Aristóteles, de todo estado de coisas que, contingente em um momento $m$, consiste em um determinado indivíduo perecível existente em $m$ não possuir um determinado predicado. Após o perecimento necessário e irreversível desse indivíduo, o estado de coisas se tornará necessário. Isso é implicado pelo modo como Aristóteles concebe as condições de verdade de enunciados que afirmam ou negam que um predicado, em um dado momento, pertence a algo que não existe nesse momento.

Com respeito aos enunciados contrários "Sócrates está doente" e "Sócrates está 
sadio", diz Aristóteles, em Categorias 10:

(...) não é necessário sempre um ser verdadeiro e o outro falso. Pois, se Sócrates existe, um será verdadeiro e o outro falso, mas, se não existe, ambos serão falsos, pois não será verdadeiro <enunciar> nem que Sócrates está doente nem que está sadio, se ele próprio absolutamente não existe. (...) Mas, quanto à afirmação e negação, quer ele exista quer não, sempre uma será falsa e a outra verdadeira. Pois <considere-se o enunciado de que $>$ Sócrates está doente e $\langle 0\rangle$ de que Sócrates não está doente; é claro que, se ele existe, um ou outro será verdadeiro ou falso, e igualmente se não existe. Pois, se não existe, é falso <enunciar> que está doente, é verdadeiro <enunciar> que não está doente. (Categorias 10, 13b15-19, 27-33)

A concepção contemporânea dos predicados ou atributos como funções proposicionais implica ser relativa a distinção lógica entre enunciados afirmativos e negativos e, consequentemente, a distinção entre estados de coisas que consistem em um predicado pertencer a alguma coisa e estados de coisas que consistem em um predicado não pertencer a alguma coisa. Segundo essa concepção, negar que Sócrates possui o predicado de ser filósofo é enunciar a ocorrência do mesmo estado de coisas que se enuncia quando se afirma que Sócrates possui o predicado de não ser filósofo, de modo que não faz sentido indagar, sem mais, se um enunciado é logicamente uma afirmação ou uma negação, se enuncia que algo possui um predicado ou que algo não possui um predicado.

Ao postular que é falsa toda afirmação e verdadeira toda negação de que algo inexistente em um dado momento possui, nesse momento, um predicado qualquer, Aristóteles deve conceber essas distinções como absolutas, sob pena de violação trivial do princípio de não contradição. Esse postulado e essa concepção subjazem à distinção aristotélica entre não possuir um predicado e possuir o predicado oposto, entre não ser $\mathrm{F}$

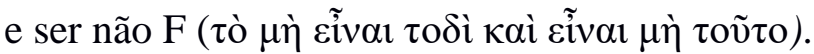

À luz dessa distinção, quem enuncia que $X$ não é $F$ não enuncia nada a respeito do que $X$ é, enuncia apenas o que $X$ não é; quem enuncia que $X$ é não $F$ enuncia algo a respeito do que $X$ é, a saber, que $X$ está em uma condição que a expressão "não F" caracteriza indefinidamente apenas pela ausência de F. Assim, o primeiro enunciado é absolutamente uma negação, o segundo é absolutamente uma afirmação. Os enunciados "X é F" e "X é não F" são ambos afirmações. Portanto, não são contraditórios, mas contrários, pois podem ser falsos ao mesmo tempo e sob o mesmo aspecto. ${ }^{42}$

Assim, todo estado de coisas e conexão predicativa cuja ocorrência implique que

\footnotetext{
${ }^{42}$ Cf. Primeiros Analíticos I 46, 51b5-35, 52a24-26.
} 
um número finito de indivíduos perecíveis determinados possuam determinados predicados está, se contingente em algum momento, destinado a se tornar impossível, ao menos a partir do momento em que esses indivíduos não mais existam. Do mesmo modo, todo estado de coisas e conexão predicativa cuja ocorrência seja implicada por um número finito de indivíduos perecíveis determinados não possuírem determinados predicados está, se contingente em algum momento, destinado a se tornar necessário. Para estados de coisas e conexões predicativas desse tipo não valem nem o princípio de plenitude forte, nem as teses estatísticas fortes que lhe são equivalentes.

Por outro lado, uma concepção estatística das modalidades condizente com nosso bom senso explanatório basta para excluir a existência de estados de coisas e conexões predicativas que, eternamente possíveis, nunca ocorrerão - e, por conseguinte, a existência de estados de coisas e conexões predicativas eternamente contingentes que sempre ou nunca ocorrerão. Deles não se pode dizer que não tiveram oportunidades nem tempo suficientes para ocorrer (não ocorrer), mas que teriam ocorrido (não ocorrido) se tivessem tido mais tempo e oportunidades, pois nunca deixarão de ter uma sucessão interminável de oportunidades futuras e uma porção interminável de tempo futuro para ocorrer (não ocorrer).

Em suma, uma concepção estatística condizente com nosso bom senso explanatório não apenas pode, mas deve restringir o domínio de aplicação do princípio de plenitude forte ao conjunto dos estados de coisas e conexões predicativas sempre possíveis, atribuindo validade universal apenas ao princípio de plenitude atenuado, compatível com a existência de possibilidades que nunca se realizaram até um dado momento e, por deixarem, nesse momento, de ser possibilidades, nunca mais se realizarão.

Essa restrição não conflita com uma interpretação caridosa dos textos de Aristóteles que, à primeira vista, parecem atestar seu compromisso incondicional com a concepção estatística forte das modalidades. Isso porque é razoável entender que esses textos concernem a domínios particulares de estados de coisas e conexões predicativas, cujas características peculiares, em conjunção com algumas teses físicas e metafísicas, se não inquestionavelmente, ao menos plausivelmente aristotélicas, implicam que neles o princípio de plenitude forte tenha validade universal.

\subsubsection{Eternidade e Necessidade}

Consideremos os textos que enunciam a equivalência entre eternidade e 
necessidade. Eles concernem expressamente ao domínio das coisas eternas. Afirmam que as coisas que existem eternamente existem necessariamente e necessariamente são tudo o que eternamente são. Do ponto de vista aristotélico, isso vale trivialmente para substâncias eternas imateriais. Sendo a matéria o princípio de toda mudança, elas são, por definição, imutáveis e, portanto, sempre foi impossível deixarem de existir, deixarem de ser o que são e passarem a ser o que não são. E isso vale também para as substâncias materiais eternas, tal como Aristóteles as concebe.

As substâncias materiais eternas, os corpos celestes, habitam uma região que Aristóteles desenha como uma série finita de esferas homocêntricas eternas, cujo centro é o da Terra, esfera eternamente imóvel. Em algumas dessas esferas celestes estão incrustados os astros ou estrelas. Na primeira esfera, a que envolve todas as demais, as estrelas fixas; em outras, as estrelas errantes, os planetas, que incluem o Sol e a Lua. Todos os corpos celestes, esferas e astros, são materialmente constituídos por um elemento, o primeiro corpo simples, distinto dos quatro que constituem materialmente as substâncias perecíveis, que habitam a Terra e a região entre ela e a última esfera, aquela que a envolve imediatamente e onde está incrustada a Lua.

Por sua natureza, o primeiro corpo simples não confere ao que ele constitui materialmente capacidade para mudar senão de lugar. Portanto, os corpos celestes não são passíveis de geração e perecimento, são necessariamente eternos. Tampouco podem ganhar ou perder predicados intrínsecos de qualquer categoria que não a de lugar, de modo que, dados um corpo celeste e qualquer um desses predicados, ou sempre foi necessário esse corpo eternamente possuir esse predicado ou sempre foi necessário eternamente não o possuir.

Por natureza, o primeiro corpo simples confere a tudo o que ele constitui apenas a potencialidade para o movimento circular. Cada uma das esferas celestes está eternamente em rotação uniforme, no que concerne à velocidade, direção e ângulo de inclinação de seu eixo de rotação relativamente ao da primeira esfera. Os polos de cada esfera, com a exceção óbvia da primeira, estão presos à esfera que imediatamente a envolve, que por isso lhe transmite seu próprio movimento. Assim, a série das esferas celestes é um sistema mecanicamente articulado, onde o movimento de cada esfera, com a exceção óbvia da primeira, é o resultado necessário da composição de seu próprio movimento de rotação com os movimentos de rotação de todas as esferas que a envolvem e carregam, imediata ou mediatamente.

Conforme as lições de Metafísica XII 8 e Física VIII, a rotação de cada esfera 
celeste é determinada pelo exercício necessário, porque sempre desimpedido, de uma capacidade natural dessa esfera e pela atividade imutável de uma substância imaterial, um motor imóvel. Por conseguinte, cada esfera necessariamente sempre roda do modo como realmente sempre roda. Ora, o resultado necessário da composição de movimentos que sempre foi necessário ocorrerem do modo como realmente ocorrem é também um movimento que sempre foi necessário ocorrer do modo como realmente ocorre. Portanto, sempre foi necessário que cada parte de uma esfera celeste, e também cada astro que nela esteja incrustado, esteja, em cada momento, passando precisamente por onde, nesse momento, está passando em sua trajetória pelo céu.

Por conseguinte, sempre foi necessário que os corpos celestes e suas partes possuam, em cada momento, todos os predicados intrínsecos, de quaisquer categorias, que realmente possuem nesse momento e não possuam todos os que realmente não possuem nesse momento. Em suma, a essência das substâncias imateriais, pura atualidade, e a natureza das substâncias materiais eternas são tais que sempre foi necessário que cada uma delas exista eternamente e seja, em cada momento, nada mais e nada menos do que realmente é nesse momento.

A ocorrência ou não ocorrência, em um dado momento, de um estado de coisas em que intervêm apenas substâncias eternas, seus predicados e suas relações mútuas depende apenas de qual seja, nesse momento, o estado do domínio total dessas substâncias, que Aristóteles entende ser causalmente independente do que aconteça de existir e ocorrer na região sublunar. Sempre foi necessário que cada substância imaterial exista eternamente, eternamente seja tudo o que é e eternamente não seja tudo o que não é. Sempre foi necessário que cada substância material eterna exista eternamente, eternamente seja tudo o que é e eternamente não seja tudo o que não é, exceto no que concerne à sua localização no céu. Portanto, diferentes estados possíveis do domínio total das substâncias eternas são diferentes tão somente no que concerne à localização das substâncias materiais eternas e suas partes na região celeste.

Dado que sempre foi necessário que cada corpo celeste, assim como cada uma de suas partes, em um dado momento esteja precisamente onde está em sua trajetória pelo céu, sempre foi necessário que o estado do domínio total das substâncias eternas, em um dado momento, seja precisamente seu estado nesse momento. Por conseguinte, considerando-se apenas os estados de coisas em que intervêm apenas substâncias eternas, seus predicados e suas relações mútuas, sempre foi necessário que, em cada momento, ocorram aqueles que realmente ocorrem e não ocorram aqueles que realmente não 
ocorrem.

Se um desses estados de coisas não ocorre em um dado momento nem nunca depois dele, então sempre foi necessário que não ocorresse nesse momento nem nunca depois dele. Por contraposição, se é possível que um desses estados de coisas ocorra em um dado momento ou depois dele, então ocorre nesse momento ou depois dele. A essência das substâncias imateriais e a natureza das substâncias materiais eternas garantem que, no domínio dos estados de coisas que não envolvem substâncias perecíveis, o princípio de plenitude forte tenha validade irrestrita, assim como as teses estatísticas fortes que lhe são equivalentes.

\subsubsection{Escalas de Modalidades e Graus de Frequência}

O domínio das substâncias eternas é, por sua própria essência e natureza, o reino da necessidade e, por isso, nele vigora o princípio de plenitude forte. Por natureza, a região sublunar abriga necessidade e contingência em dosagens variadas e, por isso, nela vigora o princípio de plenitude apenas em uma versão atenuada. No entanto, pressupostas algumas teses plausivelmente aristotélicas e a validade dessa versão atenuada do princípio, mesmo nessa região há um conjunto de estados de coisas e conexões predicativas com respeito aos quais a escala das quatro modalidades (necessidade, contingência branda, contingência em grau máximo e impossibilidade) equivale a uma escala de quatro graus de frequência (o que é sempre, o que é no mais das vezes, o que é às vezes, mas não no mais das vezes e o que nunca é). E isso é tudo o que um intérprete caridoso está obrigado a encontrar nos textos de Aristóteles que, à primeira vista, parecem implicar a validade universal dessa equivalência.

Do ponto de vista aristotélico, até o momento da morte de Sócrates, foi possível que o predicado expresso por "está conversando com Sócrates" pertencesse a alguém; após esse momento, isso se tornou impossível, tornou-se necessário que ninguém conversasse ou viesse a conversar com Sócrates. Do mesmo modo, até o momento em que Édipo furou os próprios olhos, foi possível que o predicado expresso por "está sendo visto por Édipo" pertencesse a algo; após esse momento, isso se tornou impossível, tornou-se necessário que ninguém fosse ou viesse a ser visto por Édipo. Esses predicados, por sua definição, são tais que o fato de ser ou não possível, em um dado momento, que pertençam ou venham a pertencer a alguma coisa qualquer depende, entre outros fatores, de quais sejam os indivíduos perecíveis que aconteçam de existir e de quais sejam as 
condições acidentais em que esses indivíduos aconteçam de estar nesse momento.

Em contraste com predicados desse tipo, chamarei de estritamente universais predicados - como os expressos por "homem", "branco", "saudável”, "move-se” - cuja possibilidade ou impossibilidade, em um dado momento, de pertencerem ou virem a pertencer, e não pertencerem ou virem a não pertencer, a alguma coisa qualquer depende apenas de quais sejam os gêneros e espécies de coisas naturais que nesse momento existam ou possam vir a existir, bem como de quais sejam os atributos e capacidades que a natureza comum aos exemplares de cada um desses gêneros e espécies comporta que eles possuam e não possuam.

No mundo aristotélico, sem evolução natural nem entropia, onde os gêneros e espécies naturais são eternos e as naturezas genéricas e específicas das coisas são imutáveis, é razoável supor que um predicado estritamente universal que, em algum momento, pode pertencer (não pertencer) ou vir a pertencer (não pertencer) a alguma coisa qualquer sempre poderá pertencer (não pertencer) ou vir a pertencer (não pertencer) a alguma coisa qualquer. Do mesmo modo, nesse mundo, um predicado estritamente universal que, em algum momento, é impossível que pertença a alguma coisa qualquer, sempre foi impossível pertencer (não pertencer) a alguma coisa qualquer.

Chamemos de estritamente universais estados de coisas e conexões predicativas constituídos apenas por predicados estritamente universais. É, portanto, razoável supor que, no mundo aristotélico, a possibilidade ou impossibilidade, em um dado momento, de ocorrer (não ocorrer) ou vir a ocorrer (não ocorrer) um estado de coisas estritamente universal e uma conexão predicativa estritamente universal dependa apenas da compatibilidade ou incompatibilidade de sua ocorrência (não ocorrência) com o conjunto imutável das regularidades naturais necessárias, inscritas na natureza imutável das espécies e gêneros eternos em que se distribuem as coisas naturais.

Assim sendo, no mundo aristotélico, é razoável supor que estados de coisas e conexões predicativas estritamente universais são sempre possíveis ou sempre impossíveis - e, portanto, pelas definições cruzadas das modalidades, sempre necessários, sempre contingentes ou sempre impossíveis. Isso implica que eles se agrupam em três classes exaustivas e exclusivas: os sempre necessários, que sempre ocorrem; os sempre impossíveis, que nunca ocorrem; e os sempre contingentes, que, à luz do princípio de plenitude atenuada, durante todo o tempo, às vezes ocorrem (no mais das vezes ou não) e às vezes não correm (no mais das vezes ou não). 
Do ponto de vista de nosso bom senso explanatório, e dado que Aristóteles concebe a explicação científica, cujo modelo idealizado expõe nos Segundos Analíticos, como o espelho discursivo da armação causal do mundo, justifica-se, pois, agrupar todas as ocorrências de estados de coisas em três tipos exclusivos:

(a) ocorrências necessárias, casos particulares de regularidades estritamente necessárias; são as ocorrências de estados de coisas ou conexões predicativas estritamente universais e continuamente necessários, que ocorrem sempre;

(b) ocorrências contingentes que são casos particulares de regularidades lacunarmente necessárias; são ocorrências de estados de coisas ou conexões predicativas estritamente universais e brandamente contingentes, que ocorrem no mais das vezes, mas nem sempre;

(c) ocorrências contingentes simplesmente irregulares, por serem contingentes em grau máximo todos os estados de coisas e conexões predicativas estritamente universais de que são ocorrências, estados de coisas e conexões predicativas que em algum momento ocorrem, mas nem sempre nem no mais das vezes.

Nesse caso, a hipótese interpretativa de que Aristóteles, no trecho inicial do capítulo 9, considere serem enunciados sobre universais apenas aqueles que afirmam ou negam a ocorrência de estados de coisas e conexões predicativas estritamente universais explicaria por que, nesse trecho, apenas enunciados a respeito de singulares fariam exceção às leis de bivalência e distribuição fortes. Se, na esfera desse tipo de estados de coisas e conexões predicativas, o que ocorre sempre é sempre necessário e o que nunca ocorre é sempre impossível, então, nessa hipótese, enunciados universais a respeito de universais seriam, se contingentes, sempre falsos, e suas negações sempre verdadeiras, de modo que apenas enunciados a respeito de singulares seriam, se agora contingentes, agora nem verdadeiros nem falsos. ${ }^{43}$

\section{Interpretações Alternativas}

Uma interpretação tradicional de De Interpretatione 9 deve resolver a ambiguidade da frase "é necessário um dos dois contraditórios ser verdadeiro ou falso", em 19a36-37, de modo a tomá-la como a formulação da lei de bivalência atenuada: é

\footnotetext{
${ }^{43}$ Amônio e Tomás de Aquino, por exemplo, sustentam que enunciados contingentes a respeito de universais tomados universalmente são todos falsos, se universais, e todos verdadeiros, se particulares. Isso evidentemente pressupõe que o princípio de plenitude forte seja universalmente válido na esfera do que afirmam ou negam os enunciados a respeito de universais, o que quer que sejam eles. Cf. Amônio, Comentário ao De Interpretatione 138, 26-139, 20; Tomás de Aquino, Comentário ao De Interpretatione I, Lição 13, 5.
} 
necessário que um ou outro dos contraditórios seja agora ou venha a ser verdadeiro ou falso. A possibilidade de resolver a ambiguidade de modo a tomá-la como a formulação da lei de bivalência forte motivou leitores renitentes em encontrar no capítulo a recusa da validade universal dessa lei a buscar alternativas à interpretação tradicional.

\subsection{As Falácias Modais}

Vimos que os trechos em que Aristóteles, no início e no final do capítulo, formula o que nele se trata de refutar são gramaticalmente ambíguos. Tomados isoladamente, pode-se neles encontrar a recusa das teses de que necessariamente todo enunciado é verdadeiro ou falso e necessariamente, dado um par de contraditórios, um é verdadeiro e o outro falso. É assim que os lê um intérprete tradicional. No entanto, neles se pode também encontrar a recusa das teses mais robustas de que todo enunciado é necessariamente verdadeiro ou necessariamente falso e, dado um par de contraditórios, um é necessariamente verdadeiro e o outro necessariamente falso. Chamo de interpretações das falácias modais aquelas que privilegiam esse segundo modo de ler os trechos - interpretações que ganharam popularidade desde meados do século passado.

Segundo essas interpretações, a lei de bivalência forte sairia incólume do confronto com o argumento determinista. Diferentemente do que pensam os intérpretes tradicionais, Aristóteles não pretenderia que esse argumento mostrasse impecavelmente que a conclusão determinista se segue da lei de bivalência forte e, portanto, pudesse servir de subargumento na redução ao absurdo dessa tese. Pelo contrário, o argumento seria, para Aristóteles, formalmente inválido, pois estaria escorado em falácias modais, que a quarta parte do capítulo se encarregaria de desmascarar.

Um intérprete tradicional encontra, em 19a23-32: (a) a distinção entre necessidade incondicional e necessidade temporalmente relativa; (b) a afirmação da tese da necessidade do presente; (c) a aplicação dessa distinção e dessa tese na delimitação precisa das implicações do princípio (irrestritamente válido) do terceiro excluído, delimitação que prepara a rejeição da bivalência forte em benefício da bivalência atenuada. Nesse mesmo trecho, interpretações das falácias modais encontram: (a) a distinção entre necessidade da consequência (X ser o caso implica necessariamente que Y é o caso) e necessidade do consequente (X ser o caso implica que necessariamente $\mathrm{Y}$ é o caso); (b) a denúncia da falácia que consiste em ignorar essa distinção e derivar, da verdade trivial de "X ser o caso implica necessariamente que X é o caso", a verdade de 
"X ser o caso implica que necessariamente X é o caso"; (c) a denúncia da falácia aparentada que consiste em derivar, da verdade de "necessariamente ou X é o caso ou $\mathrm{X}$ não é o caso", a verdade de "ou necessariamente X é o caso ou necessariamente X não é o caso".

Segundo as interpretações das falácias modais, o argumento determinista de algum modo (a respeito do qual elas divergem) derivaria cavilosamente, por meio de uma ou outra dessas falácias, ou de ambas, a tese de que todo enunciado é necessariamente verdadeiro ou necessariamente falso (que implica trivialmente o determinismo), a partir da tese (supostamente inocente) de bivalência forte. Assim, o argumento redutivo como um todo seria, de fato, uma refutação válida apenas da primeira tese, e não da bivalência forte. O propósito do capítulo seria denunciar o ardil determinista e inocentar a bivalência forte de qualquer envolvimento com o determinismo. ${ }^{44}$

A validade formal do argumento determinista é, do ponto de vista aristotélico, inquestionável, desde que às suas premissas explícitas - a lei de bivalência forte e a tese de que a verdade (falsidade) de um enunciado implica necessariamente que ocorre (não ocorre) o que ele diz que ocorre (não ocorre) - se acrescentem, como premissas implícitas, as teses da necessidade do presente e do passado e a lei modal inquestionável segundo a qual o que se segue do necessário é também necessário. As interpretações das falácias modais fazem dessas falácias os fundamentos da etapa inferencial que, segundo os intérpretes tradicionais, é legitimamente garantida pela necessidade do presente e do passado: a passagem da bivalência forte à afirmação de que todo enunciado é necessariamente verdadeiro ou necessariamente falso em algum sentido do termo modal relevante para o estabelecimento da tese determinista. Portanto, se coerentes, interpretações das falácias modais parecem estar necessariamente comprometidas com a negação de que a necessidade do presente e do passado seja pressuposta por Aristóteles no capítulo. Sem esse compromisso, parece que nada autorizaria que se tachasse essa passagem de falaciosa.

No entanto, a negação de que a necessidade do presente e do passado seja pressuposta no capítulo põe os adeptos dessas interpretações diante de um dilema aparentemente insolúvel. Para estigmatizar como inválido o argumento determinista, eles parecem ser obrigados a negar que Aristóteles, no capítulo, suponha ser hoje necessário,

\footnotetext{
${ }^{44}$ Diferentes interpretações dessa espécie são expostas, por exemplo, em Anscombe 1956, Strang 1960, Rescher 1963, Fine 1984, Judson 1988. Spellman demonstra simpatia por elas, mas reconhece suas dificuldades; cf. Spellman 1980.
} 
no sentido que esse termo modal possa ter no capítulo, que ocorra hoje ou tenha ocorrido no passado tudo o que realmente ocorre hoje ou ocorreu no passado. Nesse caso, seria certamente falacioso o passo inferencial que, no argumento determinista, leva da bivalência forte à tese de ser todo enunciado hoje necessariamente verdadeiro ou hoje necessariamente falso. Em contrapartida, porém, parece que se tornaria assim impossível interpretar os trechos inicial e final do capítulo sem afrontar escandalosamente o princípio de caridade. Isso porque a mesma escolha interpretativa que permitiria a esses intérpretes apresentar o argumento determinista como falacioso parece obrigá-los a apresentar a conclusão do capítulo, que esses trechos expõem, como escandalosamente falsa.

É inquestionável que a conclusão do capítulo é a afirmação não apenas de que uma certa tese não vale universalmente para enunciados sobre o futuro, mas a afirmação de que uma certa tese, que vale universalmente para os enunciados sobre o presente e o passado, não vale universalmente para os enunciados sobre o futuro. Segundo as interpretações das falácias modais, essa tese não seria a bivalência forte: esta valeria universalmente para enunciados sobre o passado, o presente e o futuro. No entanto, aparentemente ela também não poderia ser, à luz do princípio de caridade, a tese de que todo enunciado é necessariamente verdadeiro ou necessariamente falso, que seria, segundo essas interpretações, o que Aristóteles pretenderia refutar no capítulo.

Com efeito, como quer que se entenda o termo modal, é inquestionável que a verdade necessária de um enunciado implica a necessidade da ocorrência do que ele diz ocorrer. Se, no sentido em que o termo modal é empregado no capítulo, há ocorrências atuais e passadas de estados de coisas que sejam agora contingentes, então, nesse sentido do termo, os enunciados que asseveram essas ocorrências são agora contingentemente verdadeiros e aqueles que negam essas ocorrências, contingentemente falsos. Isso é o mesmo que dizer que, no sentido em que o termo modal é empregado no capítulo, nem todo enunciado sobre o presente e o passado é agora necessariamente verdadeiro ou necessariamente falso. Na hipótese de não ser agora necessário que esteja acontecendo agora ou tenha acontecido ontem uma batalha naval que realmente está acontecendo agora ou aconteceu ontem, então os enunciados que asseveram estar acontecendo agora ou ter acontecido ontem uma batalha naval não seriam agora necessariamente, mas apenas contingentemente, verdadeiros. Tanto quanto os enunciados sobre o futuro contingente, os enunciados sobre o presente contingente e o passado contingente não seriam agora nem necessariamente verdadeiros nem necessariamente falsos.

Em suma, as interpretações das falácias modais podem dar conta do bloco de texto 
que expõe o argumento redutivo, tomado isoladamente, e podem dar conta do bloco descontínuo de texto que expõe a conclusão que Aristóteles pretende extrair em $D e$ Interpretatione 9, tomado isoladamente. No entanto, aparentemente elas não podem dar conta de ambos os blocos em conjunto, pois aquilo de que precisam para dar conta de um é precisamente o que as impede de dar conta do outro. ${ }^{45}$

O dilema só não é realmente insolúvel porque há uma, e não mais que uma, maneira logicamente possível de sustentar conjuntamente a ilegitimidade formal do argumento determinista e a validade universal das teses da necessidade do presente e do passado. Ela consiste em declarar ilegítima a aplicação dessa tese na inferência de que todo enunciado é agora necessariamente verdadeiro ou necessariamente falso a partir da suposição de que todo enunciado é agora (foi no passado) verdadeiro ou falso, simplesmente porque enunciados como "É (foi) verdadeiro (falso) que haverá uma batalha naval amanhã", que atribuem verdade e falsidade a enunciados sobre o futuro, não seriam, apesar da aparência gramatical, enunciados sobre o presente e o passado.

Essa estratégia de enfrentamento de argumentos deterministas do tipo do exposto por Aristóteles em De Interpretatione 9, à qual são afeitos muitos de nossos contemporâneos, foi há séculos vislumbrada por Cícero. ${ }^{46}$ Trata-se de postular que o uso das expressões predicativas "é (foi, será) verdadeiro que” e "é (foi, será) falso que” é governado, a título de definições nominais, pela variante do esquema-T de Tarski e seu análogo no que concerne à falsidade: para todo enunciado E, dizer que é verdadeiro (falso) em $m$ que E seria, por definição nominal, dizer que E (não E). Sendo assim, a referência temporal no definiendum seria supérflua, pois dizer que um enunciado é verdadeiro em um momento equivaleria a dizer que ele é verdadeiro em todos os momentos.

Essa definição deflacionária neutralizaria, pois, a referência temporal do verbo principal em enunciados da forma literal "É (foi, será) verdadeiro (falso) que E”. O enunciado "É verdadeiro que haverá uma batalha naval amanhã", por exemplo, não diria nada mais e nada menos do que diz o enunciado sobre o futuro "Haverá uma batalha naval amanhã". Assim, apesar do tempo do verbo principal, também ele seria um enunciado

\footnotetext{
${ }^{45}$ Ao defender uma interpretação das falácias modais, Gail Fine recusa que as teses da necessidade do presente e do passado sejas pressupostas no argumento da batalha naval. No final das contas, vê-se obrigada a admitir que não dispõe de resposta satisfatória à questão de saber o que Aristóteles pretende que vale para os enunciados sobre o presente e o passado, mas não para os enunciados sobre futuros contingentes. Mais que o reconhecimento de uma dificuldade, essa admissão soa como a confissão de um fracasso (cf. Fine 1984, 38-40).
}

${ }^{46}$ Cf. Cícero, De Fato IX. 
sobre o futuro - imune, portanto, à necessidade do presente. Sendo a expressão "é verdadeiro", assim como "é falso", atemporal ou temporalmente neutra, ele não afirmaria que algum estado de coisas ocorre no presente, e sim que o estado de coisas que consiste em haver uma batalha naval ocorre no momento em que esse enunciado diz que ocorre a saber, no futuro.

A estratégia de invocar uma suposta peculiaridade de enunciados da forma “É (foi) verdadeiro (falso) que E" para isentar de obediência às teses da necessidade do presente e do passado o que esses enunciados dizem ser o caso não é, em si mesma, (ao menos evidentemente) absurda e merece ser considerada. No entanto, não é nada plausível a hipótese interpretativa de que tenha sido ela a utilizada por Aristóteles para refutar o argumento determinista em De Interpretatione $9 .{ }^{47}$

Admitir a hipótese implica admitir que o elo fraco do argumento determinista seria, para Aristóteles, não propriamente o recurso às falácias modais supostamente expostas na quarta parte do capítulo, mas o suposto fato de, nesse argumento, enunciados que exprimem atribuições de verdade e falsidade - supostamente peculiares, por serem atemporais ou temporalmente neutros - serem tratados como se fossem enunciados quaisquer. Ora, nada no capítulo e, particularmente, nenhum trecho de sua quarta parte, em que Aristóteles supostamente revelaria a causa da ilegitimidade formal do argumento determinista, nem de longe sugere que os predicados "é verdadeiro" e "é falso" sejam atemporais ou temporalmente neutros e enunciados que os contêm como predicados sejam semanticamente peculiares, muito menos que essa suposta peculiaridade, derivada desse suposto caráter atemporal ou temporalmente neutro, explique a ilegitimidade do argumento. Assim, ao expor a refutação do argumento, Aristóteles teria simplesmente omitido o fundamento último da refutação. Isso confere à hipótese um grau de plausibilidade praticamente indiscernível de zero.

\subsection{Os Peripatéticos de Simplício}

No que toca ao domínio de validade da lei de bivalência, Simplício apresenta a posição dos peripatéticos como intermediária entre a tese estoica segundo a qual, por já estar desde sempre inflexivelmente determinado tudo o que ocorrerá no futuro, todo enunciado é verdadeiro ou falso, e a tese de Nicostrato segundo a qual, por ainda não estar

\footnotetext{
${ }^{47}$ Essa hipótese interpretativa foi adotada, por exemplo, em Judson 1988.
} 
inflexivelmente determinado tudo o que ocorrerá no futuro, nem todo enunciado é verdadeiro ou falso. Entre esses dois extremos, os peripatéticos sustentariam que todo enunciado é verdadeiro ou falso, seja ele sobre o passado, o presente ou o futuro, mas com uma ressalva importante. Enquanto todo enunciado sobre o presente e o passado já

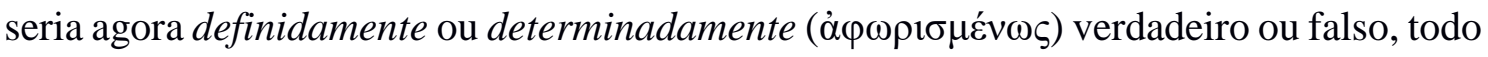
enunciado sobre o futuro seria por certo agora verdadeiro ou falso, mas nem todos já seriam agora definidamente ou determinadamente verdadeiros ou falsos.

A estratégia para contornar o argumento determinista mediante recurso à distinção entre ser simplesmente verdadeiro ou falso e ser definidamente verdadeiro ou falso talvez remonte a pelo menos três séculos antes desse testemunho de Simplício. Em um texto em forma de diálogo, incertamente atribuído ao notório peripatético Alexandre de Afrodísia, mas certamente provindo do círculo de seus seguidores próximos, o personagem que conduz o diálogo sustenta que o determinismo é consequência inevitável da tese de que um ou outro de um par de enunciados contraditórios é definidamente verdadeiro. Isso ao menos sugere a admissão da possibilidade de ser inofensiva para o indeterminista a tese de sempre ser um ou outro verdadeiro, embora nem sempre definidamente. ${ }^{48}$

Essa estratégia é expressamente atribuída a Aristóteles nos comentários ao De Interpretatione de Amônio e Boécio, fontes de inspiração para muitos comentadores medievais do tratado, como Al-Farabi e Tomás de Aquino. Admitindo-se que esses comentários de fato reproduzam, no essencial, a espécie de interpretação de $D e$ Interpretatione 9 adotada pelos peripatéticos aos quais se Simplício se refere, que rotularei de peripatética, haveria então uma terceira espécie de interpretações do capítulo a ser considerada como alternativa à tradicional e à das falácias modais. Seria ela propriamente uma terceira espécie? Acredito que não.

O fato é que, para resolver a ambiguidade da frase em 19a36-37 de modo a fazer Aristóteles nela afirmar que todo enunciado é verdadeiro ou falso sem, com isso, conceder ao determinista a premissa crucial de seu argumento, as interpretações peripatéticas recorrem a uma expressão não menos ambígua. Trata-se da expressão "ser verdadeiro ou falso, mas não determinadamente ou definidamente", cuja diferença semântica em relação a "ser determinadamente ou definidamente verdadeiro ou falso" seria o salvo-conduto para o indeterminista aderir sem culpa à lei universal de bivalência. Nada nos comentários de Amônio e Boécio propicia uma solução indiscutível para essa ambiguidade, o que os

${ }^{48}$ Cf. Alexandre de Afrodisia, Quaestio 1.4, 12, 13-19. 
torna eles próprios passíveis de duas metainterpetações.

É indisputável que, nesses comentários, os contextos primitivos em que os advérbios "determinadamente" e "indeterminadamente" são empregados como termos técnicos são contextos dos tipos "de um par de contraditórios, um é verdadeiro e o outro é falso" e "o enunciado E é verdadeiro ou falso". Nos contextos do primeiro tipo, os advérbios remetem a dois modos como dois atributos podem se relacionar predicativamente com os elementos de um par, cada um dos atributos com um único elemento; naqueles do segundo tipo, remetem a dois modos como algo pode se relacionar predicativamente com um dos membros de uma disjunção exclusiva de atributos, com a qual de algum modo se relaciona predicativamente.

É indisputável o que significa, nesses comentários, dizer que, dado um par de enunciados contraditórios, agora um deles é verdadeiro e o outro falso determinadamente, assim como dizer que um enunciado é agora verdadeiro ou falso determinadamente. No primeiro caso, significa dizer que, dado o par de contraditórios, um deles é agora verdadeiro, um deles é agora falso e está agora determinado qual é agora o verdadeiro e qual é agora o falso. No segundo caso, significa dizer que o enunciado possui agora um e apenas um desses dois valores de verdade e agora já está determinado qual deles ele agora possui e qual deles agora não possui. Portanto, é indisputável que ser um enunciado agora determinadamente verdadeiro ou falso implica ser ele agora atualmente verdadeiro ou ser ele agora atualmente falso, assim como ser agora determinadamente um dos membros de um par de contraditórios verdadeiro e o outro falso implica ser um deles agora atualmente verdadeiro e o outro agora atualmente falso. A questão crucial para a compreensão da interpretação peripatética de De Interpretatione 9 é: seriam também válidas as implicações inversas?

Entendido o conectivo de disjunção seja como extensional, seja como intensional, seu uso ordinário é tal que "X é A ou B" é incompatível com "X não é A e X não é B". Analogamente, o uso ordinário do quantificador particular é tal que "dados $\mathrm{X}$ e $\mathrm{Y}$, um deles é A e o outro é B" é incompatível com "X não é A e X não é B e Y não é A e Y não é B". Por conseguinte, responder negativamente a essa questão equivale a dizer que haveria dois modos de um enunciado possuir agora, atualmente, o atributo de ser verdadeiro (falso). Haveria enunciados agora atualmente verdadeiros (falsos) cuja verdade (falsidade) agora já estaria determinada e haveria enunciados agora atualmente verdadeiros (falsos) cuja verdade (falsidade) agora ainda estaria indeterminada. Os primeiros seriam determinadamente, verdadeiros ou falsos, os outros o seriam 
indeterminadamente.

Responder afirmativamente àquela questão equivale a dizer que haveria dois modos mutuamente excludentes de um enunciado relacionar-se predicativamente com o atributo disjuntivo de ser verdadeiro ou falso. Seria agora determinadamente verdadeiro ou falso um enunciado que possuísse agora, atualmente, o atributo de ser verdadeiro ou falso, entendendo-se uma expressão da forma "X é atualmente A ou B" no sentido ordinário, em que é incompatível com "X não é atualmente A e X não é atualmente B". E seria agora indeterminadamente verdadeiro ou falso um enunciado que mantivesse agora com esse atributo uma relação predicativa mais fraca que a relação de posse atual, a exemplo da relação predicativa meramente potencial que um embrião mantém com o atributo de ser homem. Do mesmo modo como um embrião ainda não é um ser humano, um enunciado agora indeterminadamente verdadeiro ou falso ainda não seria atualmente verdadeiro ou falso.

Entender que a interpretação peripatética pressupõe a resposta negativa é entender, pois, que atribui a Aristóteles a distinção entre, por um lado, enunciados que são atualmente verdadeiros (falsos) em um momento $m$ e está determinado em $m$ serem verdadeiros (falsos) em $m$ e, por outro lado, enunciados que são atualmente verdadeiros (falsos) em $m$, mas não está determinado em $m$ serem verdadeiros (falsos) em $m$. Em outros termos, é entender que atribui a Aristóteles a distinção entre enunciados atualmente verdadeiros (falsos) em $m$ que são, em $m$, necessariamente verdadeiros (falsos) e enunciados atualmente verdadeiros (falsos) em $m$ que são, em $m$, apenas contingentemente verdadeiros (falsos). Isso implica, pois, recusar as teses da necessidade do presente e do passado ou, ao menos, restringir sua esfera de validade, por subtração do que dizem os enunciados que consistem em atribuições de verdade e falsidade.

Portanto, entender que a interpretação peripatética pressupõe a resposta negativa à questão crucial é entender que atribui a Aristóteles não a recusa da validade universal da lei de bivalência forte, mas a afirmação de que enunciados sobre futuros contingentes não são ou determinadamente (isto é, necessariamente) verdadeiros ou determinadamente (isto é, necessariamente) falsos, mas nem por isso deixam de ser ou indeterminadamente (isto é, atual e contingentemente) verdadeiros ou indeterminadamente (isto é, atual e contingentemente) falsos. Assim, interpretações peripatéticas nada mais seriam que exemplares antigos da interpretação das falácias modais, tão pouco plausíveis quanto 
vimos serem os exemplares contemporâneos. ${ }^{49}$

Em contrapartida, entender que a interpretação peripatética pressupõe a resposta afirmativa à questão crucial é entender que atribui à Aristóteles a tese de que os enunciados sobre futuros contingentes se distinguem dos demais pelo fato de serem agora apenas indeterminadamente - e, portanto, não atualmente verdadeiros ou falsos. Nenhum seria agora atualmente verdadeiro e nenhum seria agora atualmente falso, mas todos manteriam com o atributo de ser verdadeiro ou falso uma relação predicativa mais fraca que a de posse atual.

Essa relação seria, ainda assim, mais forte que a de mera potencialidade, forte o suficiente para justificar o reconhecimento de que o atributo de ser verdadeiro ou falso participa da essência do discurso enunciativo. Ser indeterminadamente verdadeiro ou falso seria não apenas poder ser verdadeiro e poder ser falso, mas também estar desde sempre determinado a vir a ser atualmente verdadeiro ou vir a ser atualmente falso - não apenas ser potencialmente verdadeiro ou falso, mas estar desde sempre determinado a atualizar essa potencialidade.

Portanto, entender que a interpretação peripatética pressupõe a resposta afirmativa à questão crucial é entender que atribui a Aristóteles a recusa da validade universal da lei de bivalência forte e a aceitação da validade universal da lei de bivalência fraca. Enunciados sobre futuros contingentes não seriam agora atualmente verdadeiros e não seriam agora atualmente falsos, mas necessariamente viriam a ser atualmente verdadeiros ou atualmente falsos. Assim sendo, interpretações peripatéticas nada mais seriam que exemplares edulcorados da interpretação tradicional.

São essas as duas metainterpretações plausíveis, ao menos em princípio, das interpretações peripatéticas, desde que se pressuponha que, nas formulações dessas interpretações, o conectivo de disjunção tenha sido empregado em seu sentido ordinário. Há, porém, quem sustente que, segundo as interpretações peripatéticas (especialmente a de Boécio), Aristóteles preserva, em De Interpretatione 9, a validade universal da lei de bivalência, com a ressalva de que, na formulação da tese, o conectivo de disjunção não deve ser entendido em seu sentido ordinário, mas em um sentido extraordinário, em que "X é A ou B" não conflita logicamente com "X não é A e X não é B". Trata-se do sentido figurado em que se diz, por exemplo, que, antes de se enfrentarem, cada um dos dois finalistas de uma competição já é seu campeão ou seu vice-campeão, porque cada um

\footnotetext{
${ }^{49}$ Essa metainterpretação é defendida, por exemplo, em Mignucci 1998 e Seel 2000b.
} 
deles já estaria agora destinado a vir a ser ou seu campeão ou seu vice-campeão - ainda que evidentemente nenhum deles já seja agora seu campeão e nenhum já seja agora seu vice-campeão. ${ }^{50}$

Nesse sentido extraordinário, um enunciado sobre um futuro contingente por certo não seria - em contraste com enunciados sobre o presente, o passado e os futuros necessários ou impossíveis - determinadamente verdadeiro ou falso, pois agora não estaria determinado que fosse agora verdadeiro e tampouco que fosse agora falso. Nesse sentido, porém, ele seria simplesmente verdadeiro ou falso, pois já estaria agora determinado que viesse a possuir, em algum momento e daí para sempre, um dos dois valores de verdade, sem que agora já estivesse determinado qual deles.

É certo que os textos dos intérpretes peripatéticos são suficientemente ambíguos para que não se possa descartar in limine essa terceira metainterpretação. No entanto, não é difícil perceber que, segundo ela, os intérpretes peripatéticos encontrariam em $D e$ Interpretatione 9, formuladas em linguagem figurada, exatamente as mesmas teses que a segunda metainterpetação entende que eles ali encontram, formuladas com palavras a serem tomadas ao pé da letra: um enunciado sobre um futuro contingente não é agora atualmente verdadeiro e não é agora atualmente falso, mas está agora destinado a vir a possuir um dos dois valores de verdade, sem que já esteja definido qual. E essas são as teses que ali encontram também os intérpretes tradicionais. A divergência entre interpretações tradicionais e peripatéticas, entendidas à luz da segunda ou da terceira metainterpretação, seria meramente verbal, concernente apenas à maneira como Aristóteles teria preferido formular essas teses em De Interpretatione 9. De todo modo, cabe observar que, embora o apelo à equivocidade de certas palavras seja uma estratégia tipicamente aristotélica de solução de aporias, nada no texto de De Interpretatione 9 indica que seja essa a estratégia de que Aristóteles lança mão para lidar com os efeitos logicamente deletérios do argumento determinista.

Interpretações peripatéticas são, divergências terminológicas à parte, ou interpretações das falácias modais, com todos os seus vícios, ou interpretações tradicionais, com todas as suas virtudes. No que concerne especialmente aos comentários de Boécio, a clareza com que eles explicitam a adesão às teses da necessidade do presente e do passado e à concepção temporal da verdade fala a favor da segunda metainterpretação. Um trecho do segundo comentário sugere uma hipótese acerca do que

\footnotetext{
${ }^{50}$ Essa metainterpetação é sustentada, por exemplo, em Kretzmann 1998.
} 
teria motivado a formulação da interpretação tradicional do argumento da batalha naval em termos da distinção entre dois modos de ser verdadeiro ou falso, distinção literalmente ausente do texto de De Interpretatione 9. O trecho sugere a hipótese de que essa formulação tenha sido cuidadosamente escolhida por razões de ordem retórica, no contexto do confronto entre o determinismo dos estoicos e o indeterminismo dos peripatéticos e epicuristas, ao qual Boécio se filiava. A respeito de pares de contraditórios, diz Boécio:

No entanto, alguns, entre eles os estoicos, julgaram que Aristóteles disse não serem os contingentes concernentes ao futuro nem verdadeiros nem falsos. Com efeito, tendo ele dito que nenhum deles está mais disposto a ser do que a não ser, julgaram por isso que seria completamente irrelevante para eles serem tomados como verdadeiros ou falsos; pois concluíram não serem nem verdadeiros nem falsos. Erroneamente, porém; pois Aristóteles não diz que ambos não são nem verdadeiros nem falsos, e sim que qualquer um deles é decerto ou verdadeiro ou falso, contudo não definidamente, tal como os concernentes ao passado e tal como os concernentes ao presente $(\ldots) .^{51}$

Se o trecho reproduz fielmente a crítica dos estoicos ao argumento de $D e$ Interpretatione 9, ela consiste em atribuir a Aristóteles a recusa da lei de bivalência forte e dela inferir uma consequência logicamente escandalosa, em si mesma e no interior da doutrina aristotélica: a inexistência de qualquer vínculo relevante entre a natureza própria do discurso enunciativo e o atributo de ser verdadeiro ou falso. A resposta de Boécio a essa crítica consistiria então em negar a validade dessa inferência e insistir que, mesmo não sendo todo enunciado atualmente verdadeiro ou falso, ainda assim todo enunciado seria de algum modo sempre verdadeiro ou falso - se não definidamente, ao menos, indefinidamente. Por razões retóricas, os estoicos teriam capciosamente omitido que Aristóteles preserva, no capítulo, uma relação necessária e essencial entre enunciados e a bivalência, ainda que atenuada. E seria também por razões retóricas que, não menos capciosamente, Boécio em nenhum momento afirma com todas as letras que, no final das contas, ser indefinidamente verdadeiro ou falso implica não ser agora atualmente verdadeiro e não ser agora atualmente falso - ainda que tampouco afirme o contrário. ${ }^{52}$

\footnotetext{
${ }^{51}$ Boécio, Segundo Comentário ao De Interpretatione, 208, 1-11.

${ }^{52}$ Sobre a crítica estoica à restrição, por Aristóteles, da lei de bivalência como provável motivo das interpretações peripatéticas, cf. Lukasiewicz, "Philosophical remarks of many-valued systems of propositional logic", in Lukasiewicz 1970, 176-177. Sobre ser meramente retórica a diferença entre interpretações peripatéticas e tradicionais, cf. Gaskin 1995, 149.
} 


\section{Conclusão: Verdade e Contingência}

A análise miúda de De Interpretatione 9 fundamenta a certeza moral de que sua interpretação à maneira tradicional é a única ao mesmo tempo coerente e plausível, à luz do texto do capítulo e seu entorno imediato. Se ela provoca desconforto, é porque parece ser impossível conciliá-la com a conjunção de três pilares da doutrina lógica de Aristóteles, suficientemente assentados sobre outros textos: o princípio irrestritamente universal do terceiro excluído, a tese de que o atributo de ser verdadeiro ou falso é a marca distintiva essencial do enunciado e a definição de verdade como concordância entre o que o enunciado diz ser o caso e o que é realmente o caso. No entanto, pode-se mostrar que isso é apenas uma aparência.

Para Aristóteles, a função própria do enunciado é dizer que estados de coisas ocorreram, ocorrem ou ocorrerão em um determinado tempo - seja um momento determinado, seja a totalidade ou uma determinada parte do tempo. Estados de coisas são tipicamente tais que, em um tempo determinado qualquer, ocorrem ou não ocorrem. Assim, enunciados são tipicamente tais que podem ser bem-sucedidos ou malsucedidos no exercício de sua função própria: bem-sucedidos, se dizem que ocorre em um tempo $t$ o que ocorre em $t$ ou não ocorre em $t$ o que não ocorre em $t$; malsucedidos, se dizem que ocorre em $t$ o que não ocorre em $t$ ou não ocorre em $t$ o que ocorre em $t$.

O valor intrínseco do que tem uma função própria é definido pelo grau de sucesso com que desempenha essa função. No caso dos enunciados, os graus são, para Aristóteles, dois, nem mais nem menos: o máximo e o nulo. Dados um estado de coisas e um tempo $t$, há, para esse estado de coisas, duas e apenas duas alternativas: o estado de coisas ocorre em $t$ ou não ocorre em $t$. É o que diz o princípio do terceiro excluído. Assim, dado um enunciado que diz que um estado de coisas ocorre em $t$, há, para esse enunciado, duas e apenas duas alternativas concernentes à excelência com que exerce sua função apofântica: ou esse estado de coisas ocorre em $t$ e o enunciado é bem-sucedido, ou o estado de coisas não ocorre em $t$ e o enunciado é malsucedido. Terceiro excluído.

Um enunciado ser bem-sucedido é, por definição, ser ele verdadeiro, ser malsucedido é, por definição, ser ele falso. Do ponto de vista de como desempenha sua função própria, há dois e apenas dois graus de valor que um enunciado pode possuir, e algum ele deve possuir: ser verdadeiro e ser falso. Em termos anacrônicos, a todo enunciado pode e deve convir um entre dois, e não mais que dois, valores de verdade. Terceiro excluído. Essa é uma marca distintiva essencial do enunciado. 
É essa caracterização, indiscutivelmente aristotélica, da natureza lógica do enunciado que parece ruir ao final de De Interpretatione 9, tradicionalmente interpretado. No entanto, uma leitura sem antolhos dos textos aristotélicos que parecem forçar a admissão da equivalência entre o terceiro excluído e a bivalência forte mostra que $D e$ Interpretatione 9, tradicionalmente interpretado, não conflita com eles, mas os complementa. De Interpretatione 9 introduz na questão da verdade, que esses textos formulam e resolvem de modo temporalmente genérico, uma nova variável, o tempo, o que leva não à retificação da solução genérica, mas à sua especificação, e consequente complicação.

Consideremos a definição formulada em Metafísica IV 7, 1011b25-27: é falso dizer não ser o que é e ser o que não é; é verdadeiro dizer ser o que é e não ser o que não é. A definição não estabelece senão que ser o caso (não ser o caso) o que um enunciado diz ser o caso é condição necessária e suficiente para o enunciado ser verdadeiro (falso). Tomada literalmente, ela não se opõe a nada que a interpretação tradicional encontra em De Interpretatione 9. Dado um enunciado que diz que algo ocorrerá em um tempo futuro, nada que essa interpretação ali encontra se opõe a que se diga que ocorrer nesse tempo futuro o que o enunciado diz que nele ocorrerá é a condição necessária e suficiente de sua verdade. ${ }^{53}$

Por desconsiderar diferenças de referência temporal entre enunciados, a definição não permite, porém, prejulgar a questão que preside o argumento da batalha naval. Essa questão é: dado que, por definição, a satisfação ou não satisfação da condição necessária e suficiente da verdade (falsidade) de um enunciado dotado de referência temporal - a ocorrência em um tempo $t$ do estado de coisas que o enunciado diz ocorrer em $t$ - é temporalmente localizada, qual a localização temporal da posse de verdade (falsidade) por esse enunciado? Sendo o definiens temporalmente localizado, qual seria a localização temporal do definiendum? Em particular, como atribuir agora valor de verdade a um enunciado sobre o futuro, antes do momento em que, por definição, será ou não será satisfeita a condição necessária e suficiente de sua verdade ou falsidade?

$\mathrm{Na}$ interpretação tradicional, um dos pressupostos do argumento da batalha naval

\footnotetext{
${ }^{53} \mathrm{O}$ mesmo vale evidentemente para a definição formulada em Metafísica IX 10, 1051b3-5, segundo a qual a condição necessária e suficiente da verdade (falsidade) de um enunciado é estar (não estar) dividido o que ele diz estar dividido ou estar (não estar) combinado o que ele diz estar combinado.
} 
é serem verdade e falsidade atributos temporalmente datados de enunciados e nada em De Interpretatione 9 permite supor que Aristóteles não o subscreva. À luz desse pressuposto, a questão de como definir o critério para a datação da posse desses atributos por enunciados não pode ser evitada e Aristóteles não a evita. Sua resposta, que é o fundamento da tese da equivalência entre determinismo e validade universal da lei de bivalência forte, é insinuada em 18b38-19a4:

Pois não é em virtude de se afirmar ou negar, não importa se há dez mil anos ou há quanto tempo que seja, que isso será ou não será. Portanto, se todo o tempo as coisas eram de um modo tal a um ou outro ser verdadeiro, então era necessário isso vir a ser e tudo o que vem a ser é sempre tal que vem a ser por necessidade.

Se o modo como as coisas são no momento $m$ e foram antes de $m$, que define o estado do mundo em $m$, determina causalmente a ocorrência no tempo $t$ do estado de coisas que um enunciado diz que ocorre em $t$, então está determinada em $m$ a ocorrência desse estado de coisas em $t$. Ora, a ocorrência do estado de coisas em $t$ é o que faz do enunciado uma representação bem-sucedida da realidade, ou seja, o que faz dele um enunciado verdadeiro. Já estando essa ocorrência determinada em $m$, já está também determinado em $m$ que o enunciado é uma representação bem-sucedida da realidade - em outros termos, que o enunciado já é verdadeiro em $m$. Analogamente, se o estado do mundo em $m$ determina causalmente a não ocorrência em $t$ do estado de coisas que um enunciado diz que ocorre em $t$, então o enunciado já é falso em $m$. E, se o estado do mundo em $m$ não determina causalmente nem a ocorrência nem a não ocorrência em $t$ do estado de coisas que um enunciado diz que ocorre em $t$, então em $m$ o enunciado ainda não é nem verdadeiro nem falso, pois ainda não chegou o tempo oportuno para ocorrer ou não ocorrer aquilo de que depende seu sucesso ou fracasso em exercer sua função apofântica .

Em suma, ser um enunciado verdadeiro (falso) em $m$ é ser necessário (impossível) em $m$ ocorrer em $t$ o que ele diz ocorrer em $t$. Assim, as teses da necessidade do presente e do passado implicam ser agora verdadeiro ou falso todo enunciado sobre o presente e o passado. E também é agora verdadeiro ou falso todo enunciado que diz que ocorrerá no futuro o que é agora necessário ou impossível que ocorra no futuro. No entanto, na hipótese de haver um estado de coisas que agora nem é necessário nem impossível que ocorra no futuro, o enunciado que diz que ele ocorrerá no futuro agora não é ainda nem verdadeiro nem falso.

É puro simplismo postular que a definição aristotélica de verdade implica a validade universal da variante do esquema-T de Tarski, pois isso equivale a ignorar as 
complicações que envolvem a relação que a verdade e a falsidade dos enunciados mantêm com a realidade quando essa relação é concebida como temporalmente localizada. Assim concebida, decorre da definição de verdade e da lei de bivalência atenuada uma versão também atenuada da variante do esquema-T: é em algum momento verdadeiro (falso) que E se, e somente se, E (não E).

Do ponto de vista aristotélico, é também puro simplismo postular que o conteúdo logicamente relevante de um enunciado temporalmente absoluto seja definido pelas condições que a realidade deve satisfazer para que ele seja agora verdadeiro. Esse conteúdo é, desse ponto de vista, definido pelas condições que a realidade deve satisfazer para que o enunciado seja verdadeiro no momento oportuno - a saber, no momento em que o enunciado diz ocorrer o que deve ocorrer para que ele seja nesse momento verdadeiro.

Por isso, é também puro simplismo, por exemplo, qualificar como fantasia ou delírio a ideia de que uma disjunção possa ser agora verdadeira sem que nenhum de seus disjuntos seja agora verdadeiro. É decerto condição necessária para que uma disjunção seja em algum momento verdadeira que ao menos um de seus disjuntos seja em algum momento verdadeiro. No entanto, dada a definição do conceito temporal de verdade, é condição necessária para que uma disjunção seja agora verdadeira que esteja agora determinado que ao menos um dos disjuntos, não importa qual, seja em algum momento verdadeiro, ainda que nenhum já seja agora verdadeiro. Portanto, a disjunção "Haverá uma batalha naval amanhã ou não haverá uma batalha naval amanhã”, por exemplo, é agora verdadeira, pois está agora determinado que ao menos um dos disjuntos será à meia-noite de amanhã verdadeiro, ainda que nenhum agora já seja verdadeiro. A restrição do domínio de validade da lei de bivalência forte não compromete nem o sentido nem a verdade do princípio universal do terceiro excluído.

Concedido o princípio de plenitude atenuada, essa restrição tampouco compromete o vínculo essencial entre os enunciados e o atributo de ser verdadeiro ou falso. A restrição apenas obriga a reconhecer que a força desse vínculo varia de acordo com os diferentes graus de determinação com que ocorrem ou não ocorrem os estados de coisas a que concernem diferentes enunciados.

No domínio dos estados de coisas que envolvem apenas substâncias eternas, seus predicados e suas relações mútuas, nada ocorre contingentemente, tudo o que ocorre sempre esteve inflexivelmente determinado a ocorrer no momento em que ocorre. Nesse domínio, vale universalmente o princípio de plenitude em sua versão mais radical, 
equivalente à tese determinista: tudo o que é agora possível ocorrer em um dado momento, é e foi desde sempre necessário ocorrer nesse momento. Por conseguinte, nele vale universalmente a versão forte da lei de bivalência.

No domínio dos estados de coisas que envolvem coisas perecíveis, seus predicados e relações, há o que ocorre contingentemente. No interior da região sublunar, contudo, o espaço de manobra da contingência é limitado por uma trama de regularidades, a maioria delas apenas condicional e lacunarmente necessárias, que repercutem causalmente as regularidades absolutamente necessárias que vigem além das fronteiras dessa região. Por isso, nela vale universalmente apenas a versão atenuada do princípio de plenitude: todo estado de coisas sempre possível em algum momento ocorrerá. E, por isso, nele vale universalmente apenas a versão atenuada da lei de bivalência: é necessário que todo enunciado seja em algum momento verdadeiro ou falso.

No que concerne a seu valor apofântico, o enunciado tem diante de si, em princípio, duas e apenas duas possibilidades, uma das quais deve se realizar, no momento oportuno: ser verdadeiro e ser falso. Por necessidade ancorada em sua essência apofântica, todo enunciado é potencialmente verdadeiro ou falso; por necessidade ancorada no princípio de plenitude atenuada, essa potencialidade em algum momento se atualiza. Como se lê em De Interpretatione 4, é uma marca distintiva de todo discurso enunciativo que nele esteja a verdade ou a falsidade - seja no modo da atualidade, seja no modo da potencialidade inflexivelmente destinada a se atualizar.

Diferentemente do que faz supor a postura defensiva dos intérpretes peripatéticos diante dos estoicos, a restrição da lei de bivalência não é, para Aristóteles, um mal necessário, mas o refinamento do conceito de verdade necessário para adequá-lo à estrutura metafísica do mundo sensível. Aristóteles considera como fundamentais e indubitáveis, em De Interpretatione 9, o princípio irrestrito do terceiro excluído e o fato bruto da existência do contingente no mundo sublunar. A questão do capítulo é: como a conjunção desse princípio com o reconhecimento compulsório desse fato repercute no conceito de verdade?

A resposta de Aristóteles a essa questão talvez seja difícil de digerir, mesmo para seus intérpretes menos longínquos do que nós, porque ousa contestar a autonomia da lógica em relação ao mundo. Para ele, os princípios de não contradição e terceiro excluído são decerto irrestrita e universalmente válidos, pois espelham, no plano discursivo, a forma universal e necessária dos estados de coisas. Já as leis da verdade variam, pois, dizendo respeito à relação entre discurso, pensamento e realidade, devem espelhar as 
especificidades das diferentes estruturas metafísicas dos diferentes domínios da realidade onde o discurso e o pensamento exercem sua função apofântica. Para Aristóteles, portanto, em oposição ao aforismo do jovem Wittgenstein, "dado que os enunciados são verdadeiros do mesmo modo como são as coisas", a lógica não é independente o bastante para poder cuidar de si mesma.

Luiz Henrique Lopes dos Santos Universidade de São Paulo / Universidade Federal do Rio de Janeiro/CNPq

\section{Referências Bibliográficas}

Al-Farabi 1981, Al-Farabi's Commentary and Short Treatise on Aristotle's De Interpretatione, London.

Ammonius 1897, In Aristotelis De Interpretatione commentarius, A. Busse (ed.), Berlin.

Ammonius 1998, On Aristotle: On Interpretation 9, David Blank (trans.), with Boethius, On Aristotle: On Interpretation 9, Norman Kretzmann (trans.), London and Ithaca.

Anscombe, G.E.M. 1956, “Aristotle and the sea battle”, Mind 65 (257), 1-15.

Aquinas Thomas 1882, Commentaria in Aristotelis libros Peri hermeneias et Posteriorum analyticorum, Editio Leonina, vol. I, Romae.

Boethius 1877/1880, Commentarii in librum Aristotelis Peri Hermeneias, C. Meiser (ed.), Leipzig.

Broadie, Sarah 1986, "On What Would Have Happened Otherwise: A Problem for Determinism", The Review of Metaphysics 39, 433-56.

Broadie, Sarah 1987, "Necessity and Deliberation: an Argument from De Interpretatione 9", Canadian Journal of Philosophy 17, 289-306.

Fine, Gail 1984, "Truth and Necessity in De Interpretatione 9", History of Philosophy Quarterly 1 (1), 23-47.

Gaskin, Richard 1995, The Sea-Battle and the Master Argument: Aristotle and Diodorus Cronus on the Metaphysics of the Future, Berlin.

Judson, Lindsay 1988, "La Bataille navale d'aujourd'hui: De Interpretatione 9", Revue de Philosophie Ancienne 6, 5-37.

Kretzmann, Norman 1998, "Boethius and the truth about tomorrow's sea battle", in Ammonius 1998, 24-52.

Lowe, Malcom F. 1980, "Aristotle on the sea-battle: a clarification", Analysis 40 (1), 55-59.

Lukasiewicz, Jan 1970, Selected Works, L. Borkowski (ed.), Amsterdam and Warszawa.

Mignucci, Mario 1998, “Ammonius' sea battle” in Ammonius 1998, 53-86 
Rescher, Nicholas 1963, “An interpretation of Aristotle's doctrine of future contingency and excluded middle", in Rescher, Nicholas 1963, Studies in the History of Arabic Logic, Pittsburgh, 43-54.

Seel, Gerhard (ed.) 2000a, Ammonius and the Sea Battle. Texts, Commentary and Essays, Berlin and New York.

Seel, Gerhard 2000b, “'In a Definite Way True'; Truth-Values and their Modalization in Ammonius", in Seel 2000a, 234-246.

Sharples, Robert 1992, Alexander of Aphrodisias: Quaestiones 1.1-2.15, London and Ithaca.

Simplicius 2000, Simplicius: on Aristotle's Categories 9-15, London.

Spellman, Lynne 1980, “DI 9: an exegetical stalemate”, Apeiron 14 (2), 115-124.

Strang, Colin 1960, "Aristotle and the sea battle", Mind 69 (276), 447-465. 